\title{
Factors influencing brook trout (Salvelinus fontinalis ) abundance in forested headwater streams with emphasis on fine sediment
}

James Philip Hakala

West Virginia University

Follow this and additional works at: https://researchrepository.wvu.edu/etd

\section{Recommended Citation \\ Hakala, James Philip, "Factors influencing brook trout (Salvelinus fontinalis ) abundance in forested headwater streams with emphasis on fine sediment" (2000). Graduate Theses, Dissertations, and Problem Reports. 1125.}

https://researchrepository.wvu.edu/etd/1125

This Thesis is protected by copyright and/or related rights. It has been brought to you by the The Research Repository @WVU with permission from the rights-holder(s). You are free to use this Thesis in any way that is permitted by the copyright and related rights legislation that applies to your use. For other uses you must obtain permission from the rights-holder(s) directly, unless additional rights are indicated by a Creative Commons license in the record and/ or on the work itself. This Thesis has been accepted for inclusion in WVU Graduate Theses, Dissertations, and Problem Reports collection by an authorized administrator of The Research Repository @ WVU. For more information, please contact researchrepository@mail.wvu.edu. 
Factors Influencing Brook Trout (Salvelinus fontinalis) Abundance in Forested Headwater Streams with Emphasis on Fine Sediment

By

James Philip Hakala

\begin{abstract}
A Thesis
Submitted to

The College of Agriculture, Forestry, and Consumer Sciences

at

West Virginia University

in partial fulfillment of the requirements

for the degree of

Master of Science

In

Wildlife and Fisheries Resources

Kyle J. Hartman, Ph.D., Chair

Patricia M. Mazik, Ph.D.

Raymond P. Morgan II, Ph.D.

J. Todd Petty, Ph.D.

Wildlife and Fisheries Program of the Division of Forestry

Morgantown, West Virginia

2000
\end{abstract}

Keywords: Brook Trout, Sediment, Habitat, Drought

Copyright 2000 James Philip Hakala 


\begin{abstract}
$\underline{\text { Abstract }}$
Factors Influencing Brook Trout (Salvelinus fontinalis) Abundance in Forested Headwater Streams with Emphasis on Fine Sediment

By
\end{abstract}

\title{
James Philip Hakala
}

The influence and relative importance of fine sediment on wild brook trout (Salvelinus fontinalis) population size was assessed. Brook trout production in headwater streams was inversely proportional to substrate permeability in one of two years, suggesting substrate composition influenced production. Results suggest the critical fine sediment size for brook trout in this study, is between $0.063 \mathrm{~mm}$ and $1.0 \mathrm{~mm}$. Further, fine sediment $(<0.063 \mathrm{~mm}$ ) should not exceed $0.6-1.0 \%$ of spawning substrate, or negative population effects may be incurred. Under normal flow conditions, fine sediment was a principal determinant of juvenile trout abundance relative to other physical and biological factors. Adult trout abundance was principally a function of stream discharge, and was potentially further influenced by fine sediment impacts on juvenile recruitment. Spatially restricted food resources, created by drought-induced low flows in year 2 of the study, are believed to have over-powered mechanisms influencing trout abundance under normal flows. 


\section{Acknowledgments}

I would like to thank the members of my graduate committee, Dr. Kyle J. Hartman, Dr. Patricia M. Mazik, Dr. Raymond P. Morgan II, and Dr. J. Todd Petty for their guidance and technical review of this research. I extend a special thanks to Mike Kaller, John Sweka, Mathew Sipe, and Randy Cook for their invaluable field efforts. I would like to thank Dr. William Thayne and John Sweka for their statistical support. A special thanks goes to Amy Patsos and C.P. Hakala for their endearing support and encouragement throughout my research endeavor. I wish to thank Dr. Ray Morgan and the staff at the Appalachian Laboratory (UMCES) in Frostburg, Maryland, for their benevolent donation of water sampling supplies and quantitative analysis of samples. Ray Menendez and Janet Clayton of the West Virginia Department of Natural Resources are thanked for their technical advice at the initiation of this project. I would also like to thank Tom Cain of the U.S. Forest Service for his project evaluation and funding appropriation. Project funding was provided for by the U.S. Forest Service, the WESTVACO Corporation and monies from the McIntire-Stennis Act to West Virginia University. 


\section{Table of Contents}

Forward

List of Tables vii

$\begin{array}{ll}\text { List of Figures } & \text { ix }\end{array}$

-Chapter 1: Introduction 1

-Chapter 2: Factors Influencing Brook Trout Abundance in Forested Headwater Streams with Emphasis on Fine Sediment

$\begin{array}{ll}\text { Abstract } & 16\end{array}$

$\begin{array}{ll}\text { Introduction } & 17\end{array}$

$\begin{array}{ll}\text { Methods } & 21\end{array}$

$\begin{array}{ll}\text { Results } & 32\end{array}$

$\begin{array}{ll}\text { Discussion } & 45\end{array}$

$\begin{array}{ll}\text { Tables } & 62\end{array}$

$\begin{array}{ll}\text { Figures } & 75\end{array}$

-Chapter 3: Drought Impact on Stream Morphology and Brook Trout Populations in Forested Headwater Streams

$\begin{array}{lr}\text { Abstract } & 89\end{array}$

$\begin{array}{ll}\text { Introduction } & 90\end{array}$

$\begin{array}{ll}\text { Methods } & 93\end{array}$

$\begin{array}{ll}\text { Results } & 99\end{array}$

$\begin{array}{ll}\text { Discussion } & 104\end{array}$

$\begin{array}{ll}\text { Tables } & 115\end{array}$

•Chapter 4: Executive Summary 127

•Literature Cited 132 
-Appendix: Detailed Study Methodologies

-Vita

165 


\section{Forward}

This thesis quantifies both biotic and abiotic factors influencing brook trout (Salvelinus fontinalis) abundance in forested headwater streams within the Monongahela National Forest, WV. For the purpose of publication, the document is presented in four chapters. Chapters two and three are separate papers: chapter two - "Factors Influencing Brook Trout Abundance in Forested Headwater Streams with Emphasis on Fine Sediment", chapter three - "Drought Impact on Stream Morphology and Brook Trout Populations in Forested Headwater Streams". Chapter one is an introductory chapter for the document, and was not intended for future publication. The fourth chapter provides and executive summary of the results and inferences drawn from this research endeavor. Literature citations for all chapters have been placed at the end of chapter four. An appendix containing a more comprehensive study methodology, than found in either chapter two or three, has been provided at the end of this document. 


\section{List of Tables}

Table 1. Mean percent composition for redd and non-redd substrate 62 collected in both years

Table 2. Mean percent less than each sediment size class for redds and non-redds collected in both years

Table 3. Average geometric mean diameter $\left(d_{g}\right)$ and fredle index $\left(f_{i}\right)$ values for redds and non-redds in both years

Table 4. Statistical comparison of differences in substrate amounts for redds and non-redds between fall 1998 and 1999

Table 5. Brook trout density in all study streams for all four survey periods 66

Table 6. Brook trout biomass in all study streams for all four survey periods 67

Table 7. Significant relations for YOY density and biomass in summer 1999 and sediment sizes for redd and non-redd substrate collected in fall 1998

Table 8. Results of non-linear regression of redd and non-redd geometric mean diameter $\left(d_{g}\right)$ and fredle index $\left(f_{i}\right)$ values and percent sediment composition for each sediment size class

Table 9. Mean baseflow water chemistry values

Table 10. Water chemistry analyses for the February 13 and May 24, 2000 storm events

Table 11. Mean daytime water temperature recorded for all streams in 1999 and 2000

Table 12. Habitat variables significantly influencing brook trout density and biomass

Table 13. Stepwise multiple linear regression results for summer 1999 and fall 1999

Table 14. Total precipitation recorded in Bartow and Elkins, WV

Table 15. Mean daytime water temperature recorded for all streams in 1999 and 2000 
Table 16. Stream discharge in each stream for summer 1999 and summer 2000

Table 17. Mean physical habitat parameters over all streams for both years

Table 18. Mean percent composition of each sediment size class for spawning substrate collected in both years

Table 19. Mean percent less than for each sieve mesh size class for spawning substrate collected in both years

Table 20. Statistical comparison of brook trout spawning substrate collected in fall 1998 and 1999

Table 21. Average geometric mean diameter $\left(d_{g}\right)$ and fredle index $\left(f_{i}\right)$ for spawning substrate collected in both years

Table 22. Total brook trout density for all streams for each sample period

Table 23. Mean adult and YOY brook trout condition for all streams for each sample period

Table 24. Mean adult and YOY brook trout length for all streams for each sample period

Table 25. Mean adult and YOY brook trout weight for all streams for each 126 sample period 


\section{$\underline{\text { List of Figures }}$}

Figure 1. Relationship between $d_{g}$ of redd substrate in fall 1998 and brook trout per-capita-birth rate in summer 1999

Figure 2. Length-frequency histograms of brook trout length for all four sample periods

Figure 3. Relationship between fine sediment $<0.063 \mathrm{~mm}$ in fall 1998 redd substrate and YOY density in summer 1999

Figure 4. Relationship between fine sediment $<0.063 \mathrm{~mm}$ in fall 1998 redd substrate and YOY biomass in summer 1999

Figure 5. Relationship between fine sediment $<0.063 \mathrm{~mm}$ in fall 1998 non-redd substrate and YOY density in summer 1999

Figure 6. Relationship between fine sediment $<0.063 \mathrm{~mm}$ in fall 1998 non-redd substrate and YOY biomass in summer 1999

Figure 7. Relationship between fine sediment $<0.063 \mathrm{~mm}$ in non-redd substrate and YOY density for both year 1 (fall 1998) and year 2 (fall 1999).

Figure 8. Relationship between fine sediment $<0.063 \mathrm{~mm}$ in brook trout redds and stream gradient in fall 1998

Figure 9. Relationship between non-trout species diversity and adult brook trout density in summer 2000

Figure 10. Relationship between average stream water depth and adult brook trout density in summer 1999

Figure 11. Relationship between average maximum pool depth and adult brook trout density in summer 1999

Figure 12. Relationship between spawning substrate area and adult brook trout density in summer 1999

Figure 13. Relationship between stream gradient and adult brook trout density in summer 1999

Figure 14. Relationship between pool area and adult brook trout density in fall 1999 


\section{Chapter 1:}

\section{Introduction}

Non-point source pollution in the form of fine sediment is the most prevalent form of water quality degradation in the United States (USEPA 1996). Fine sediment, in the context of fisheries, generally refers to particles comprising only $10 \%$ of streambed material (Everest et al. 1987). Common practices leading to accelerated sedimentation of waterways include agriculture, logging, road construction, mining and human development. Few watersheds in the U.S. can be considered unaffected by these common anthropogenic perturbations (USEPA 1996, Williams et al. 1996).

In West Virginia, logging is a primary source of fine sediment inputs to streams. However, in the Monongahela National Forest, WV, the primary source of fine sediment is from roadways (T. Cain, USFS Monongahela National Forest, personal communication). The United States Forest Service (USFS) believes brook trout (Salvelinus fontinalis) production in the Monongahela National Forest is potentially limited by fine sediment inputs from interior roadways (Angradi and Vinson 1996, T. Cain, USFS Monongahela National Forest, personal communication). Conflicting results have been reported concerning the fine sediment issue in the Monongahela National Forest. McCullough (1997), working in the Monongahela National Forest, concluded fine sediment $<4.0 \mathrm{~mm}$ had no apparent influence on young of the year (YOY) brook trout density. His results showed counter-intuitively a weak positive relation to fine sediment $<4.0 \mathrm{~mm}$. USFS data (unpublished) collected over the same region suggested fine sediment $<4.0 \mathrm{~mm}$ had an inverse effect upon brook trout abundance. These contradictory findings may be a consequence of the size material used to define "fine 
sediment" $(4.0 \mathrm{~mm})$. Fine sediment is generally assumed to be detrimental to salmonid survival to emergence from the gravel. However, fine sediment sizes deemed harmful to larger salmonids (see reviews by Everest et al. 1987, Chapman 1988) may not necessarily apply to the smaller brook trout $(<250 \mathrm{~mm})$ native to Appalachia. There is evidence suggesting that smaller salmonid eggs and fry have a higher survival rate than larger species in sediment impacted substrate (Hall and Lantz 1969, Phillips et al. 1975, Koski 1981, Tappel and Bjornn 1983, van den Berghe and Gross 1989). Therefore, the conflicting findings presented are possibly an artifact of using $4.0 \mathrm{~mm}$ as a measure of fine sediment. The value may not adequately define or represent "fine sediment" as it pertains to the smaller brook trout found within the headwater systems studied.

Road surfaces are a significant source of fine sediment (Cederholm et al. 1980, Shepard et al. 1984, Everest et al. 1987). Unfinished roadways have a greater potential for fine sediment production than paved road surfaces (Reid et al. 1981). Sediment production from a road is positively correlated to the frequency of its use and maintenance (Wald 1975, Reid et al. 1981, Scrivener and Brownlee 1989, Grayson et al. 1993). In addition, fine sediment produced from roads is often of smaller particle sizes (<2.0 mm) (Reid et al. 1981, Reid and Dunne 1984, Everest et al. 1987, Grayson et al. 1993).

Geographic region, climate, hydrology, geology, soil type and vegetative characteristics influence stream substrate composition at a large-scale (Iwamoto et al. 1978, Everest et al. 1987). The "flushing rate" at which streams remove fine sediment is dependent upon regional precipitation rates. High stream flows remove fine sediment from the substrate (Beschta and Jackson 1979, Adams and Beschta 1980, Scrivener and 
Brownlee 1989, Dolloff et al. 1994), thus adding to spatial and temporal variation in streambed composition (Adams and Beschta 1980).

At the watershed scale, factors including basin relief, slope, area and land-use have an influence on substrate composition (Everest et al. 1987). Adams and Beschta (1980), working in Oregon Coastal streams, demonstrated an inverse relationship between watershed slope and fine sediment levels. The inverse relationship between watershed slope and fine sediment retention is suggested to be a function of water velocity. Steeper gradient watersheds have higher water velocities, which in turn may aid in the removal of fine sediment as suggested by Reiser and Wesche (1977).

Hydrologic subtleties within a stream influence measurements of streambed composition. Adams and Beschta (1980) found significant spatial differences in substrate composition for sample locations in the same stream and within the same riffle. Variation was attributed to both spatial and temporal forces acting within the system. Everest et al. (1987) stated that channel asperity (e.g. large woody debris, large cobble/boulder) augments spatial variation in sediment levels due to hydraulic sorting of the streambed substrate. Variability in fine sediment levels has also been attributed to depth within the substrate, with more fine sediment at greater depths (Peterson 1978, Adams and Beschta 1980, Everest et al. 1982, Scrivener and Brownlee 1989, Young et al. 1989).

In addition to variation in fine sediment attributed to steam morphology, salmonid behavioral adaptations contribute to spawning bed irregularity. Redd construction promotes coarsening of the substrate (Ringler 1970, Platts et al. 1979, Everest et al. 1987, Chapman 1988, Grost et al. 1991, Snucins et al. 1992). Young et al. (1989) demonstrated 
brook trout $(<250 \mathrm{~mm})$ were able to significantly reduce the amount of fine sediment less than $1.7 \mathrm{~mm}$ from within the egg pocket. The eggs are therefore deposited into an area that is "cleaner" than the surrounding substrate.

There are several accepted techniques for measuring and interpreting substrate composition of spawning gravel (Chapman and McCleod 1987). Percent fines have been used extensively as a measure of spawning substrate quality (Chapman 1988). Other measures of substrate quality include geometric mean diameter $\left(d_{g}\right)$ and the fredle index $\left(f_{i}\right)$. The $d_{g}$ is an estimate of the average particle size in a sample and is positively correlated to substrate permeability (Platts et al. 1979) and salmonid survival (MacCrimmon and Gots 1986, Scrivener and Brownlee 1989). Platts et al. (1979) concluded that $d_{g}$ was "at least" as good a measure as percent fine sediment in assessing substrate quality. The $f_{i}$ is a measure of the substrate permeability and interstitial pore size, both of which evaluate the egg rearing potential of the substrate. (Chapman and McCleod 1987). Lotspeich and Everest (1981), using the data of Philip et al. (1975) showed that survival to emergence of coho salmon and steelhead was positively associated with $f_{i}$ values. Later research by Scrivener and Brownlee (1989) established the same relationship in wild populations of coho and chum salmon (Oncorhynchus keta) in Carnation Creek, British Columbia. One should note than an inverse relation exists between percent fine sediment and measures of $d_{g}$ and the $f_{i}$ (Platts et al. 1979, Everest et al. 1982, MaGee et al. 1996). Visual estimates, such as embeddedness, have also been employed with reasonable precision for qualitative substrate evaluation (Platts et al. 1983). 
A variety of substrate sizes and amounts have been identified as detrimental to the early life stages of salmonids. Shepard et al. (1984) showed reduced bull trout (Salvelinus confluentus) survival when spawning substrate exceed $30 \%$ of material smaller than $6.4 \mathrm{~mm}$ in the Flathead river basin of Montana. Chinook salmon (Oncorhynchus tshawytscha) and rainbow trout (Oncorhynchus mykiss) emergence in laboratory troughs was reduced by sediment $<6.0 \mathrm{~mm}$ (McCuddin 1977). Mortality of both species began to increase when fine sediment $<6.0 \mathrm{~mm}$ exceeded $20-25 \%$ of the substrate. Field study of survival to emergence of coho salmon (Oncorhynchus kisutch) was highly correlated to sediment finer than $3.3 \mathrm{~mm}$ in redds (Koski 1966). Survival declined sharply over the range of $27-51 \%$ composition $<3.3 \mathrm{~mm}$. When sediment $<3.3$ mm composed approximately $30 \%$ of the total substrate sample, percent survival to emergence was 50\%. Brown trout (Salmo trutta) survival to emergence from artificial redds was negatively correlated to fines $<2.0 \mathrm{~mm}$ (Maret et al. 1993). This same size class was identified as detrimental to brook trout survival and emergence in laboratory experiment's when levels exceeded more than $20 \%$ of the substrate composition (Hausle and Coble 1976). Argent and Flebbe (1999) determined in laboratory manipulations that brook trout survival to emergence in substrate containing $25 \%$ fines $(0.43-0.85 \mathrm{~mm})$ was nearly half that of survival in treatments containing $0 \%$ fine sediment. A number of studies have identified sediment finer than $0.85 \mathrm{~mm}$ as the critical size class influencing salmonid survival and emergence (Cederholm et al. 1980 - coho salmon, Tappel and Bjornn 1983 - steelhead, Reiser and White 1988 - chinook salmon and steelhead). Smaller fine sediment $(0.06-0.5 \mathrm{~mm})$, at $8 \%$ composition, had a greater negative impact on Atlantic salmon (Salmo salar) survival than did coarser fine sediments (0.5-2.2 mm) 
in laboratory studies (Peterson and Metcalfe 1981). Clearly, sediment research has identified no clear critical size class deleterious to salmonids in general.

Caution must be exercised when interpreting the results of sediment studies. For the larger relative sediment size classes identified there is no way of ascertaining what percent composition of the substrate was composed of smaller particles. The gravel composition is an important consideration when assessing intragravel survival (Reiser and White 1988). Much of the research pertaining to fine sediment sizes and amounts harmful to salmonid success have been conducted in the western United States on the larger trout and salmon species (see review by Everest et al. 1987 and Chapman 1988). However, there are some notable laboratory studies assessing brook trout survival and emergence under varying fine sediment loads (Hausle and Coble 1976, Argent and Flebbe 1999). Inherently substrate sizes used by salmonids for nest construction are related to fish size (Chapman 1988). Reiser and Wesche (1977) reported that brown trout of larger size than brook trout, spawning in the same stream, utilized larger substrate than brook trout. Therefore, it would be expected that fine sediment sizes and amounts influencing survival of the smaller brook trout are potentially different than values recognized for larger salmonids. The fact that brook trout eggs $(\sim 4.0 \mathrm{~mm}$ diameter $)$ are smaller than most salmonid eggs warrants further investigation of the hypothesis (Wydoski and Cooper 1966).

In general, substrate used by brook trout $(<250 \mathrm{~mm})$ is comprised mainly of material $<32 \mathrm{~mm}$. Hausle and Coble (1976) excavated ten brook trout redds in Lawrence Creek, Wisconsin. They reported a mean of $31 \%$ sand (range $21-54 \%$ particles $<2.0$ $\mathrm{mm}$ ) in the redds sampled. Estimate of the length of brook trout having constructed the 
sampled redds was not made, but indication was given that spawning fish were one and two year old fish, which would likely be of similar size to the brook trout of this study. Reiser and Wesche (1977) analyzed the tailspill substrate composition of 54 brook trout (152-254 $\mathrm{mm} \mathrm{TL})$ redds, reporting $70 \%$ of the substrate was between $3.35-50.54 \mathrm{~mm}$. Snucins et al. (1992) reported that egg pocket substrate had a geometric mean diameter $\left(d_{g}\right)$ of 1.0-4.1 mm and fredle index $\left(f_{i}\right)$ values of 0.1-1.8.

Laboratory studies on fine sediment and salmonids abound in the literature (Philips et al. 1975, Hausle and Coble 1976, Peterson and Metcalfe 1981, Reiser and White 1988, Argent and Flebbe 1999). Sediment sizes and amounts identified under laboratory conditions provide useful data, but applicability in natural systems has been questioned (Everest et al. 1982). Everest et al. (1987) suggested further research at the watershed scale is required to fully assess fine sediment impacts on an entire population. Natural variability and the species physiological adaptations potentially mitigate the effects of fine sediment at a population scale (Bams 1969, Everest et al. 1987). For example, a small number of successful redds located in a patch of clean substrate within a highly sedimented stream may produce enough viable young to compensate for heavier sediment related losses over the entire system (MaGee et al. 1996).

Fine sediment influences salmonid survival in a number of ways. The intragravel period of salmonid development is generally associated with the highest mortality rates. Fine sediment has been shown to reduce survival during this critical period (see review by Everest et al. 1987 and Chapman 1988). Filling of the interstitial spaces with fine particulates creates two problems for developing embryos and emerging fry. The first is blockage of the interstitial spaces within the substrate resulting in the entrapment of 
surface migrating fry. A number of researchers have documented reduced escapement rates of emerging fry with increasing fine sediment amounts (Hall and Lantz 1969, Phillips et al. 1975, Witzel and MacCrimmon 1981, Shepard et al. 1984).

The second and more complex effect of fine sediment occurs during embryo development. The indirect effect fine sediment has upon substrate permeability is the causal mechanism decreasing salmonid survival during the critical intragravel period (Lotspeich and Everest 1981). A host of researchers have demonstrated inverse relationships between fine sediment levels and substrate permeability or intragravel flow (Bianchi 1963, McNeil and Ahnell 1964, Cooper 1965, Bjornn 1969, McCuddin 1977, Meehan and Swanston 1977, Platts et al. 1979, Reiser and White 1988, Argent and Flebbe 1999). Substrate permeability is positively related to salmonid survival (Cooper 1965, Peterson 1978, Reiser and White 1988), as water flow is the principal mechanism for oxygen delivery to the developing embryos (Silver et al. 1963). Reduction in water flow (permeability) through the substrate, as a result of increasing fines, causes reductions in intragravel dissolved oxygen concentration (Hausle 1973, Tagart 1984, Argent and Flebbe 1999) and decreases salmonid survival (Burton et al. 1990 and Maret et al. 1993).

There is both an acute and chronic effect of fine sediment upon the early life stages of salmonids. Outright mortality of eggs and emerging fry may be considered acute, whilst reductions in growth may be considered chronic in nature. Silver et al. (1963) reported rainbow trout and chinook salmon incubated under low dissolved oxygen concentrations were "smaller and weaker" than controls. Argent and Flebbe (1999) reported brook trout incubated in Vibert boxes with fine sediment $(0.43-0.85 \mathrm{~mm})$ 
levels $<15 \%$ had significantly greater body weights than those incubated at $>20 \%$ fine sediment. Decreased fry size lowers competitive ability, thus reducing post-emergence survival (Chapman 1966). Quinn and Peterson (1996) showed a positive relation to overwinter survival of coho salmon and body size in autumn, suggesting lower overwinter survival of fish populations suffering lower growth rates in sediment impacted systems.

Premature and prolonged emergence of salmonids has been documented as a consequence of increasing fine sediment levels (Koski 1966, 1981, Hausle and Coble 1976, Witzel and MacCrimmon 1981, Tappel and Bjornn 1983, and MacCrimmon and Gots 1986). Premature emergence is a behavioral response thought to be a consequence of unfavorable interstitial gravel conditions (low DO) (Bams 1969, Witzel and MacCrimmon 1981). Delayed emergence suggests fry were less affected by hypoxic conditions and instead experienced difficulty during surface migration (Koski 1966).

At a larger scale, fine sediment can alter the environment creating less favorable conditions for survival primarily through reduction in habitat availability (Cordone and Kelley 1960). Klamt (1976), using artificial and natural stream channels, demonstrated reductions in salmonid numbers following sediment additions to the channels.

Reductions were attributed to loss of available pool habitat. Similar results were reported by Hillman et al. (1987), for chinook salmon in a highly sedimented Idaho stream system.

Aquatic invertebrates are the primary food source for stream dwelling salmonids (Curtis 1959, Chapman 1966, Allen 1969, Waters 1982). Chronic inputs of fine sediment decrease aquatic invertebrate density (Cordone and Kelley 1960, Waters 1982, Hawkins et al. 1983, Hartman et al. 1996) and potentially cause shifts in benthic community 
composition (Klamt 1976). Reductions or changes in macroinvertebrate composition inherently influence salmonid production. Sediment resistant macroinvertbrate species (e.g. chironomids) are not readily available to the primarily drift feeding salmonid (Chapman 1966, Elliot 1973). As a result, fewer prey items are available for consumption.

Habitat. - The physical attributes of a stream can strongly influence salmonid abundance (Lewis 1967, Stewart 1970, Fraley and Graham 1981, Lanka et al. 1987, Scarnecchia and Bergersen 1987, Herger et al. 1996, Beard and Carline 1991, Quinn and Peterson 1996). Researchers have identified a number of physical habitat variables governing salmonid populations in streams (Fausch et al. 1988).

Stream depth influences salmonid abundance and biomass (Stewart 1970, Kennedy and Strange 1982, Scarnecchia and Bergersen 1987). Deeper average stream water depths have been associated with higher salmonid abundance (Stewart 1970, Scarnecchia and Bergersen 1987). Water depth and salmonid abundance relationships potentially have and age-related component. Kennedy and Strange (1982) reported brown trout and Atlantic salmon fry densities were significantly higher in shallower habitats $(<20 \mathrm{~cm})$, with greater adult abundance in deeper water $(>20 \mathrm{~cm})$. Other researchers have reported similar relations between water depth and age-specific abundance (Bisson et al. 1982, Bozek and Rahel 1991b, Titus and Mosegaard 1992). The above research suggests water depth complexity is an important component in maintaining habitat suitable for all salmonid age classes. 
Research has indicated salmonid abundance is positively related to pool area (Hunt 1971, Bowlby and Roff 1986). Flebbe (1999) reported a preference of brook trout for pool habitats in southern Appalachian stream systems. Bonneau and Scarnecchia (1998) demonstrated a preference by cutthroat and bull trout for pool habitats in a high gradient (3-8\%) stream system. Herger et al. (1996), and Hankin and Reeves (1988) also reported higher densities of salmonids in pools than in riffles, suggesting the amount of pool habitat is an important component governing salmonid stream abundance (Hunt 1971). In addition, trout density within pools is a function of the amount of cover present (Lewis 1969). Salmonids tend to be found in greater densities as instream cover improves (Wesche 1974, Fraley and Graham 1981, Bisson et al. 1982, Heifetz et al. 1986).

Riffle habitat is the primary location of food production for stream fish (Hawkins et al. 1983, Platts et al. 1983, Rosenfeld and Hudson 1997, Buffagni and Comin 2000). The amount of food available directly influences fish production (Allen 1969). Therefore, the amount of riffle habitat present may reflect salmonid production potential. The above research clearly indicates both pool and riffle habitats are important features governing salmonid densities. Hence, an optimal balance in both habitat types would provide for greatest salmonid production. The pool to riffle ratio (pool area divided by the riffle area) is a measure of a stream's capacity to support the habitat requirements of fishes (Platts et al. 1983). Optimal ratios are assumed to be near 1:1 (Armour et al. 1983, Platts et al. 1983), however exceptions have been documented (Platts 1974). 
Salmonids utilize bottom substrate for cover (Gibson 1978, Bonneau and Scarnecchia 1998). As substrate complexity (variation in substrate sizes) increases so does the potential for salmonid production. Scarnecchia and Bergersen (1987) demonstrated a positive relation between cutthroat and brook trout production and substrate complexity. Increases in salmonid density with increases in substrate complexity may be a factor of increasing visual isolation of fish (Stewart 1970). As salmonids are territorial (Mason and Chapman 1965, Allen 1969, Slaney and Northcote 1974), increasing isolation has been shown to decrease territory size (Allen 1969, LeCren 1973), and potentially increases overall salmonid stream densities.

Stream vegetative canopy cover governs both allochthonous nutrient inputs and autochthonous stream production. Stream sections with little or no canopy cover can be more productive than areas of dense canopy cover (Hawkins et al. 1983). However, associated changes in stream flow and water temperature may out-weigh the benefits of increased primary production for salmonids. Maximum and daily water temperature fluctuation increases as shading from riparian vegetation decreases (Brown and Krygier 1970, Hunt 1979). Higher maximum water temperatures may limit or reduce salmonid production where canopy density is low (Wohl and Carline 1996).

Logging practices at the turn of the century both removed large woody debris (LWD) from the stream channel, and ceased or reduced the forest's ability to replenish wood fiber to the system. Secondary-growth forests have a reduced capacity to input LWD to the stream relative to rates of old growth forests (Flebbe 1999). As a consequence, the legacy of forest disturbance may take upwards of 100 to 200 years before pre-disturbance input levels of LWD are realized (Koski 1992). The influence of 
LWD on salmonid population size has been intensively researched (Fausch and Northcote 1992, Flebbe and Dolloff 1995, Harvey 1998, Inoue and Nakano 1998). The frequency or volume of LWD within the stream has been positively correlated to salmonid abundance (Hartman et al. 1996, Flebbe 1999). Large woody debris increases stream habitat complexity, promoting increased salmonid survival (Hunt 1971, Quinn and Peterson 1996). Further, LWD incorporated into the stream channel acts to stabilize the streambed (Bisson et al. 1987) and aids in nutrient storage (Raikow et al. 1995).

Salmonid abundance has been demonstrated to be proportional to the availability of spawning substrate. Beard and Carline (1991), studying Pennsylvania brown trout populations, found a significant relation between the density of YOY and adult brown trout and the amount of spawning habitat. Similar results have been reported for cutthroat trout (Bozek and Rahel 1991b).

Several researchers have shown salmonid abundance decreases with increases in stream gradient (Chisholm and Hubert 1986, Lanka et al. 1987, Kozel et al. 1989). This phenomenon was attributed to differences in habitat quality between low and high gradient systems. Lower gradient streams had more pool habitat (Kozel et al. 1989) as well as larger hydrologic extremes creating less favorable habitat conditions (Lanka et al. 1987).

The primary objective of these analyses was to identify important physical stream habitat variables controlling brook trout abundance in the streams studied. The data were not intended for the development of predictive models of brook trout abundance. The restrictive geographic area and small relative sample size (Fausch et al. 1988) would make for a model of questionable usage and weak predictive capabilities. 
Drought. - Low flow conditions alter habitat unit composition and quality (Kraft 1972). The survival rate in streams during drought conditions is thought to be dependent upon the number of residual pool habitats (Binns 1994). Low flows reduce biological carrying capacity (Randolph and White 1984, Nelson 1980); fish growth and condition (Randolph and White 1984); increase water temperatures (Hunt 1979, Wohl and Carline 1996) and decrease dissolved oxygen concentrations (Brooker et al. 1977, Elliot 2000). Researchers have suggested that natural or drought enhanced low summer water flows limit salmonid carrying capacity (Lestelle et al. 1993, Elliot 1993).

Project Relevance and Objectives. - Assessment of fine sediment effects at the population level is a needed area of research. Under natural conditions the "physical features of natural streams, life history and behavioral adaptations of salmonids mitigate the effects of sediment on fish populations" (Everest et al. 1987). This study will account for those factors by assessing sediment influence on brook trout at the population scale.

Beside species specific differences attributed to geographic variation, fine sediment research as it pertains to salmonids has been largely conducted in the western United States with few exceptions (McCullough 1997, Argent and Flebbe 1999). Geographic characteristics influence fine sediment attributes (Iwamoto et al. 1978) further warranting the validity of fine sediment research conducted in the eastern United States geographic region.

Seldom have researchers analyzed the influence of sediment sizes below $0.43 \mathrm{~mm}$ on salmonid survival. Thus, it is possible that sizes smaller than $0.43 \mathrm{~mm}$ are of greater 
importance to survival and emergence success of brook trout than larger sediment sizes (Argent and Flebbe 1999).

This study was initiated to address the following four objectives: 1) characterize brook trout spawning substrate; 2) ascertain if substrate composition was influencing brook trout production; 3) determine critical fine sediment sizes and threshold amounts detrimental to brook trout abundance; and 4) establish the relative importance of fine sediment in relation to other physical and biological stream variables. Drought conditions experienced in the summer of the first year of study afforded further opportunity to assess the impact of a large-scale climatic event on stream morphology and brook trout populations in headwater stream systems. 


\title{
Chapter 2:
}

\section{Factors influencing brook trout abundance in forested headwater streams with emphasis on fine sediment}

\author{
Abstract \\ The influence and relative importance of fine sediment on wild brook trout (Salvelinus \\ fontinalis) population size was assessed over a two-year period, in seven first and second \\ headwater streams in the Monongahela National Forest, West Virginia. The objectives of \\ the study were to: 1) characterize brook trout spawning substrate; 2) ascertain if substrate \\ composition was influencing brook trout production; 3) determine critical fine sediment \\ sizes and threshold amounts detrimental to brook trout abundance; and 4) establish the \\ relative importance of fine sediment in relation to other physical and biological stream \\ variables. Brook trout spawning substrate was generally comprised of $75 \%$ particles < 32 \\ $\mathrm{mm}$, with approximately $27 \%<4.0 \mathrm{~mm}$. Brook trout production was inversely \\ proportional to substrate permeability in one of two years, suggesting substrate \\ composition was influential in setting stream production. In that year, young of the year \\ brook trout abundance was negatively influenced by the amount of fine sediment $<0.063$ \\ mm. Further analyses, suggest the critical fine sediment size, as applied to brook trout in \\ this study, is between $0.063 \mathrm{~mm}$ and $1.0 \mathrm{~mm}$. Further, fine sediment $<0.063 \mathrm{~mm}$ should \\ not exceed $0.6-1.0 \%$ of brook trout spawning substrate, or negative population effects \\ may be incurred. The lack of relation in brook trout production and YOY abundance in \\ year two, to measures of substrate composition was thought to be the consequence of \\ severe drought over-powering and/or reducing our ability to detect a relationship. \\ Moreover, higher average fine sediment $(<0.063 \mathrm{~mm})$ levels over all streams may have
}


further hindered our ability to detect a relationship in year 2. Brook trout abundance was positively associated with average stream water depth, average maximum pool depth, stream gradient, amount of suitable spawning substrate, and pool area in the first year of study. Brook trout abundance was negatively related to non-trout species diversity. Again, the lack of relation to habitat variables in year two was surmised to be a consequence of drought conditions over-powering and/or hindering our ability to detect relationships. Under normal flow conditions, fine sediment was a principal determinant of juvenile trout abundance relative to other physical and biological factors. However, intercorrelation between fine sediment levels and stream gradient complicated assessment of fine sediment importance on brook trout abundance. Adult trout abundance was principally a function of stream discharge, but under normal flow abundance was also related to juvenile abundance the previous year. Thus, under "normal" flow conditions, fine sediment may impact recruitment to the adult population, and therefore is of importance to forest management initiatives.

\section{Introduction}

Non-point source pollution in the form of fine sediment is the most prevalent form of water quality degradation in the United States (USEPA 1996). Fine sediment, in the context of fisheries, generally refers to particles comprising only $10 \%$ of streambed material (Everest et al. 1987). Common land uses leading to accelerated sedimentation of waterways include agriculture, logging, road construction, mining and landscape development. Few watersheds in the U.S. can be considered unaffected by these common anthropogenic perturbations (USEPA 1996, Williams et al. 1997). 
In West Virginia, logging is a primary source of fine sediment inputs to streams in forested watersheds. However, in the Monongahela National Forest, WV the primary source of fine sediment is from recreational roadways (T. Cain U.S. Forest Service, Monongahela National Forest, personal communication). The United States Forest Service (USFS) believes brook trout production in the Monongahela National Forest is potentially limited by fine sediment inputs from interior roadways (Angradi and Vinson 1996, T. Cain USFS, Monongahela National Forest, personal communication). Unfinished road surfaces are a significant source for fine sediment production (Cederholm et al. 1980, Shepard et al. 1984, Everest et al. 1987). Sediment originating from roads is often of smaller grain sizes than inputs from other erosional sources (Reid et al. 1981, Reid and Dunne 1984, Everest et al. 1987, Grayson et al. 1993). Moreover, smaller fine sediment, has greater potential to harm developing embryos and fry relative to larger grain sizes (Peterson and Metcalfe 1981, Reiser and White 1988).

Conflicting results have been reported concerning the influence of fine sediment on brook trout populations within the Monongahela National Forest. McCullough (1997) concluded fine sediment $<4.0 \mathrm{~mm}$ had no influence on YOY brook trout abundance in the Monongahela National Forest. In contrast, USFS data (unpublished) suggested that fine sediment $<4.0 \mathrm{~mm}$ had an inverse effect upon brook trout abundance. These contradictions may be a consequence of the size sediment analyzed (percent $<4.0 \mathrm{~mm}$ ). There is evidence suggesting smaller salmonid eggs and fry have higher survival rates than larger species in sediment impacted substrate (Hall and Lantz 1969, Phillips et al. 1975, Koski 1981, Tappel and Bjornn 1983, van den Berghe and Gross 1989). Therefore, 
the conflicting findings are possibly an artifact of using a sediment size not adequately representing "fine sediment" as it pertains to the smaller Appalachian brook trout.

In general, substrate used by brook trout $(<250 \mathrm{~mm})$ is comprised mainly of material < $32 \mathrm{~mm}$. Hausle and Coble (1976) excavated ten brook trout redds in Lawrence Creek, Wisconsin reporting a mean of $31 \%$ sand (range $21-54 \%$ particles $<2.0 \mathrm{~mm}$ ) in the redds sampled. Reiser and Wesche (1977) analyzed the tailspill substrate composition of 54 brook trout $(152-254 \mathrm{~mm}$ TL) redds. They reported $70 \%$ of the substrate was between 3.35-50.54 mm. Snucins et al. (1992) reported that brook trout egg pocket substrate had a geometric mean diameter $\left(d_{g}\right)$ of $1.0-4.1 \mathrm{~mm}$ and fredle index $\left(f_{i}\right)$ values of $0.1-1.8$

Excess inputs of fine sediment have life history, food chain and habitat associated implications for salmonid populations. Fine sediment reduces salmonid survival during the intragravel period (Koski 1966, Hausle and Coble 1976, Cederholm et al. 1980, Argent and Flebbe 1999) through reduced substrate permeability (Platts et al. 1979, Reiser and White 1988, Argent and Flebbe 1999). In addition, it has harmful effects upon aquatic invertebrates, (Waters 1982, Hawkins et al. 1983, Hartman et al. 1996) the primary food source for stream dwelling salmonids (Curtis 1959, Chapman 1966, Allen 1969, Waters 1982). At a larger scale, fine sediment can alter the environment creating less favorable conditions for survival through loss of habitat (Cordone and Kelley 1960, Klamt 1976, Hillman et al. 1987).

The physical attributes of a stream can strongly influence salmonid abundance (Lewis 1967, Stewart 1970, Fraley and Graham 1981, Lanka et al. 1987, Scarnecchia and Bergersen 1987, Herger et al. 1996, Beard and Carline 1991, Quinn and Peterson 1996). 
Researchers have identified a number of physical habitat variables governing salmonid populations in streams (Fausch et al. 1988). Stream depth has been shown as a factor influencing salmonid abundance and biomass (Stewart 1970, Kennedy and Strange 1982, Scarnecchia and Bergersen 1987). Deeper stream water depths are often associated with higher salmonid abundance (Stewart 1970, Scarnecchia and Bergersen 1987). Herger et al. (1996), and Hankin and Reeves (1988) reported higher densities of salmonids in pools than in riffles. However, riffle habitat is the primary location of food production in streams (Hawkins et al. 1983, Platts et al. 1983, Buffagni and Comin 1992, Rosenfeld and Hudson 1997). The amount of food available directly influences fish production (Allen 1969), and may therefore reflect brook trout production potential. Salmonids utilize bottom substrate for cover (Gibson 1978, Bonneau and Scarnecchia 1998). As substrate complexity increases so to does salmonid production potential (Scarnecchia and Bergersen 1987). The relationship may be a factor of increasing visual isolation (Stewart 1970). Stream sections with little or no canopy cover can be more productive than areas of dense canopy (Hawkins et al. 1983). However, associated changes in stream flow and water temperature (Brown and Krygier 1970, Hunt 1971) may out-weigh the benefits of increased primary production for salmonids. Large woody debris (LWD) influence on salmonid population size has been extensively examined (Fausch and Northcote 1992, Flebbe and Dolloff 1995, Harvey 1998, Inoue and Nakano 1998). The amount of LWD within the stream has been positively correlated to salmonid abundance (Hartman et al. 1996, Flebbe 1999).

Identification of variables influencing brook trout abundance in headwater streams will further the capabilities of those charged with managing this dynamic 
resource. Assessment of the factors influencing both young of the year and adult brook trout populations will provide further insight into those mechanisms influencing population size on an age-specific basis. Factors governing one life stage potentially differ, and may have repercussions on future population size.

This research endeavor was initiated to address the following four objectives: 1) to determine the substrate composition utilized by brook trout $(<250 \mathrm{~mm}$ TL) in easternforested headwater streams; 2) to evaluate if fine sediment was influencing wild brook trout production within the study streams; 3) to identify fine sediment sizes and levels influencing brook trout abundance at the population scale; 4) and to assess the relative importance of fine sediment in relation to other biotic and abiotic factors.

\section{Materials and Methods}

Study Area. - The study area is located within the east central portion of the Monongahela National Forest, West Virginia. The National Forest is located in the central Appalachian region of the U.S. Study streams are first and second order (Strahler 1957) headwater streams located in the East Fork of the Greenbrier (GR) and the North Fork of the South Branch of the Potomac River (PR) drainage's. The two watersheds lie on either side of the eastern continental divide and have an underlying sedimentary geology consisting predominantly of Chemung and Hampshire shale. Stream elevations range from 900 $1150 \mathrm{~m}$ above sea level.

The seven study streams were located in Pocahontas and Pendleton Co., WV (drainage locations in parentheses). They include Elleber Run (GR), Lick Run (GR), Long Run (GR), Mullenax Run (GR), Poca Run (GR), Little Low Place (PR) and 
Sawmill Run (PR). Study streams are not stocked and all support wild brook trout populations. Fishing pressure has not been quantified in the area, but seems to increase with stream size, reputation of the fishery (J. Hakala, personal observation) and accessibility (McCullough 1997). Fishing pressure appeared to be light to non-existent in all streams with greater use of some occurring in late winter and early spring (J. Hakala, personal observation). All streams except Little Low Place are un-manipulated watercourses. At Little Low Place there are 19 habitat improvement structures (k-dams, v-dams) constructed in the 1960's and 1990's. These structures have generally created large deep pools in their lee.

For all streams, sources of fine sediment exceeding natural production are presumably from roadways, with one stream likely having additional agricultural sediment inputs. One stream does not have an active forest road in its watershed, and correspondingly had the lowest fine sediment $(<0.063 \mathrm{~mm})$ levels in both years. Roads generally run parallel to streams and range in distance from 0 to approximately $100 \mathrm{~m}$ from the stream.

Methods. - Streams were selected for study based upon data collected by the USFS in 1997 (unpublished). Selected streams were representative of varying fine sediment loads and brook trout abundance. Streams in relative close proximity to one another (same watersheds) in geologic regions conducive to good year-round water quality were selected to minimize the effect geographic differences may have on salmonid densities (Lanka et al. 1987). Three $50 \mathrm{~m}$ sample reaches were permanently established at the lower, middle and upper portion of each study stream. In summer 1999, the $50 \mathrm{~m}$ sample 
reaches were expanded to $100 \mathrm{~m}$ in length (Armour et al. 1983) to better account for naturally high variations in stream fish densities (Wydoski and Cooper 1965, Platts and Nelson 1988). Total sample reach length averaged 18\% (range 9-29\%) of total study stream lengths.

Post-assessment of sample reaches was made to determine if sample reaches were statistically representative of stream morphology over the entire study stream. A modified basinwide habitat assessment technique (BVET) (Hankin and Reeves 1988) was used to collect habitat data over the entire study streams. Comparison was made of average stream wetted width, average maximum pool depth, pool cover rating, canopy cover and pool and riffle area between the sample reaches and the entire stream. Nonparametric t-test's (Wilcoxon signed ranks test) and 95\% CI were used to statistically evaluate if the representative sample reaches were morphologically similar to the rest of the stream.

Habitat assessments were conducted near baseflow conditions over a one-week period in late June of 1999 and 2000 in all sample reaches. USGS stage height data for the Greenbrier River at Durbin, WV (approximately 4 miles from study area) showed stage height during the June 1999 and 2000 habitat survey varied less than $0.01 \mathrm{~m}$ in both sample periods (Ward 2000, S. Ward USGS, personal communication, preliminary data 2000). Stream discharge was measured once a year in a single location using U.S. Geologic Survey techniques (USGS 1977).

Habitat data were collected using both a habitat-based (Dolloff et al. 1997) and transect-based (Platts et al. 1983) sample designs. The habitat-based design was used for measurements of the following ten habitat variables: unit type, length, wetted width, unit 
area, pool to riffle ratio, average depth, maximum pool depth, pool cover quality, volume LWD and area of suitable spawning substrate. Substrate size composition, substrate embeddedness and percent vegetative canopy cover were measured using a transectbased design.

Three habitat unit types (pool, riffle or glide) were classified based on general descriptive guidelines (Bisson et al. 1981). Habitat units were measured using standard methodologies (Dolloff et al. 1997, Overton et al. 1997). Water depth complexity was measured through calculation of the coefficient of variation (CV). Maximum water depth within pools was measured at the estimated deepest location. Additionally, pool habitats were rated subjectively for their potential to provide cover for fish using rating criteria modified from Platts et al. (1983). All suitable spawning substrate was quantified as an area (Bozek and Rahel 1991b, Magee et al. 1996). Substrate ranging from 4.0 to $30.0 \mathrm{~mm}$ in at least $7.0 \mathrm{~cm}$ of low velocity water (generally tails of pools) was considered suitable spawning substrate (J. Hakala, personal observation).

Large woody debris was defined as being greater than 1.0 meter in length and larger than $10.0 \mathrm{~cm}$ in diameter (Flebbe 1999). All pieces of LWD within the bankfull area of the stream were enumerated, and lengths and trunk diameters were measured for calculation of mass volume. Large woody debris was characterized as "functioning" or "non-functioning". A functioning piece was either directly in the water, over the wetted area of the stream and below bankfull height, or stabilizing the stream bank or streambed. Non-functioning pieces included those spanning or protruding over the stream above the bankfull height or lying on a dry area of the streambed wetted only during high flows. 
Substrate size was measured for 105 particles/sample reach (>100 recommended by Overton et al. 1997) using the Wolman Pebble Count technique (Wolman 1954). Particles $>350 \mathrm{~mm}$, including bedrock, were recorded as $350 \mathrm{~mm}$. Those $<1.0 \mathrm{~mm}$ were recorded as $1.0 \mathrm{~mm}$. Substrate complexity was assessed by calculating the $\mathrm{CV}$ of particles measured. Substrate embeddedness was estimated visually at each transect (Platts et al. 1983). Percent vegetative canopy cover at full leaf out was visually estimated at each transect using a sighting tube (PVC pipe).

Reach gradient was measured using a clinometer over an approximate $50 \mathrm{~m}$ distance in each sample reach (Lanka et al. 1987). Readings were taken at similar morphological locations in the thalweg of the stream (Overton et al. 1997).

Water Chemistry. - Water chemistry data were collected in situ near baseflow conditions at monthly intervals beginning in November 1998 and continuing through September 2000. Parameters measured include: $\mathrm{pH}$, dissolved oxygen (DO) (mg/L), percent DO saturation, and specific conductance $(\mathrm{ms} / \mathrm{cm})$.

To assess water quality during storm conditions, water samples were collected during two spring high flow events in February and May 2000. Water samples were analyzed at the Appalachian Laboratory in Frostburg, MD. The following parameters were analyzed using United States Environmental Protection Agency guidelines: dissolved organic content (DOC) (mg/L), pH, acid neutralizing capacity (ANC) (ueq/L), alkalinity (mg/L), calcium (mg/L), magnesium (mg/L), total aluminum (mg/L), organic aluminum (mg/L), and inorganic aluminum $(\mathrm{mg} / \mathrm{L})$. 
Water temperature data were collected continuously every hour from April 17, 1999 through September 2, 2000 using Onset Corporation HOBO temperature loggers. Loggers were permanently affixed to the stream bottom using a PVC housing, chain, and rebar to anchor the unit in place.

Daily precipitation data were collected from National Oceanic and Atmospheric Administration (NOAA) weather observatories located in Bartow, WV and Elkins, WV. Precipitation data collected at the Bartow station was compared to 30-year average precipitation data collected at the Elkins station to assess relative flow conditions for a given year or season (no such long-term data available at Bartow station).

Substrate Collection. - Substrate sampling was conducted during the fall spawning period in both fall 1998 and fall 1999 using a plastic grain scoop. As this is a modification of the shovel sampling technique (Grost et al. 1989), a controlled experiment was conducted to test if significant differences existed between sediment composition for samples collected with the grain scoop and a standard shovel (see methods in appendix for experimental design). No statistical differences in sample efficiency (retention of greater amounts of fine sediment) were detected, and neither device showed a greater efficiency for collecting smaller fine particulates (e.g. $<0.25$ $\mathrm{mm})$.

Substrate samples were collected from known brook trout redds over the entire length of all study streams. Substrate sampling was not restricted to the sample reaches because of the difficulty in collecting adequate numbers of samples. To avoid erroneous sample collection, only redds occupied and readily visible by their "cleaned" appearance 
were sampled (Dechant and West 1985, Young et al. 1989, Grost et al. 1991). Two substrate samples were collected at each known redd location. One sample was taken directly from the redd, and the other collected adjacent to the redd in an undisturbed area of the same gravel patch (Crisp and Carling 1989). From this point, samples collected adjacent to redd sites will be referred to as non-redd samples. Samples taken from redds included the cleaned portion of the tailspill and the entire egg pocket. The non-redd samples were assumed representative of the background substrate composition prior to redd construction (Young et al. 1989, Grost et al. 1991). Substrate samples were taken to a depth of $8.0 \mathrm{~cm}$, the average egg pocket depth found for brook trout of similar size $(<$ $25 \mathrm{~cm}$ ) as those in this study (Young et al. 1989).

An average of 12 substrate samples (range 10-16 excluding Mullenax Run) were collected annually from each study stream. One-half of the samples were collected from redds and the other half from non-redd locations. No redd samples were collected from Mullenax Run in either year due to extremely low trout densities and an inability to locate redds. This stream was excluded from further substrate analyses in both years. Sawmill Run was not used as a study stream until after fall 1998, thus no substrate samples were collected in that year. Substrate samples were collected and processed as described in the appendix of this document. Sediment sizes analyzed were >32.0, 16.0, $8.0,4.0,2.0,1.0,0.5,0.25,0.125$ and $<0.063 \mathrm{~mm}$.

The geometric mean diameter $\left(d_{g}\right)$, sorting coefficient $\left(S_{o}\right)$ (Krumbein and Pettijohn 1938) and fredle index $\left(f_{i}\right)$ were calculated for each sample using the equations of Lotspeich and Everest (1981). The $d_{g}$ is an estimate of the average particle size and a relative measure of substrate permeability. The $S_{o}$ a measure of the particle distribution 
of the substrate. The fredle index $\left(f_{i}\right)\left(f_{i}=d_{g} / S_{o}\right)$ (Lotspeich and Everest 1981) is a measure of the substrate permeability and interstitial pore size, both of which evaluate the egg rearing potential of the substrate (Chapman and McCleod 1987).

Non-linear regression was employed to ascertain which fine sediment sizes most influenced substrate permeability, as measured by the $d_{g}$ and $f_{i}$. Values obtained for the $d_{g}$ and $f_{i}$ in both years were regressed on all sediment size classes for redds and non-redds separately. Sediment sizes identified as negatively influencing either measure were then used in stepwise multiple linear regression (MLR) to identify the most influential size class.

Population Surveys. - Population surveys were conducted in October 1998, July 1999, October 1999 and July 2000 during near baseflow conditions in all sample reaches. Fish were collected using a Coffelt Model-12 backpack electrofisher. The direct pulsed DC electrofishing unit operated at a frequency of 60 hertz and a voltage range of 250-400 V depending on water conductivity. Kocovsky et al. (1997) demonstrated no long-term population effects on a salmonid population electrofished for eight years using similar techniques under comparable stream conditions. All fish species were removed using a standard three-pass removal technique (as recommended by Riley and Fausch 1992).

The CAPTURE program (White et al. 1982) was used to calculate separate maximum-likelihood population estimates and 95\% CI for age 0 (YOY) and age $1+$ (adult) brook trout. If less than 30 fish (YOY or adult) were captured in a given sample reach (as was frequently the case), then the actual number captured was used in lieu of an estimate. This is based on the findings of Riley and Fausch (1992) that the maximum- 
likelihood removal estimate "performs poorly" at sample sizes less than 30 individuals. The program CAPTURE runs a chi-square analysis to determine if the model assumption of equal catch probability between passes was satisfied. If the assumption was not satisfied for a particular population estimate, then the raw total catch was bootstrapped using the average catch efficiency for those estimates satisfying the model's assumption. Failure to meet the model's assumption occurred infrequently. Catch efficiency was calculated as the quotient of the actual number of fish captured and the derived population estimate for a sample reach (Lohr and West 1992). Depletion removal of nontrout species was poor as a result of prioritizing the capture of brook trout during sampling. Therefore, non-trout species total catch was used as opposed to mathematically estimating population size for all streams.

All brook trout captured were measured (total length $=\mathrm{TL}$ ) to the nearest $1.0 \mathrm{~mm}$ and weighed using a Pesolo spring scale to the nearest $1.0 \mathrm{gm}$. All other species were enumerated and weighed in species specific conglomeration. Brook trout condition (Fulton-type) was calculated using the formula $\mathrm{K}=\mathrm{W} / \mathrm{L}^{3}$ (where $\mathrm{K}=$ condition; $\mathrm{L}=$ total fish length; $\mathrm{W}=$ fish weight) (Anderson and Gutreuter 1983). As brook trout spawn in the fall, those captured in the October 1998 and 1999 sample surveys were checked for sex and ripeness (presence of eggs or milt). This allowed for determination of length at maturity, and sex ratios prior to the peak spawning period (Beard and Carline 1991). Determination of YOY and adult fish was done through analysis of length-frequency histograms. Age at length was verified for 40 fish using scale samples. Brook trout percapita birth rate (production) was estimated as the ratio of the number of YOY captured in summer surveys to numbers of adult females captured in the previous fall survey. 
Estimate of the number of females was calculated by multiplying the percent of females in a section (as determined by checking for ripeness) by the total number of adult brook trout captured.

To demonstrate relative YOY densities at the time of summer sampling were representative of densities shortly after emergence, visual counts of YOY were conducted over $50 \mathrm{~m}$ of every stream sample reach. Bozek and Rahel (1991a) found a strong correlation $(r=0.92, p<0.05)$ between stream bank visual counts of YOY cutthroat trout (Oncorhynchus clarki) and subsequent electrofishing survey results. Visual counts of YOY brook trout were conducted in May of 1999 over three consecutive days. One side of the stream bank was walked at a constant pace counting all YOY observed from the water's edge to the center of the stream. This method effectively sampled $1 / 4$ of the entire $100 \mathrm{~m}$ sample reach. The total number of fish observed in the section was then multiplied by 4 to account for the other $3 / 4$ of the sample reach not observed. Average numbers of YOY were calculated over the three observation days. Simple linear regression analysis was used to compare relative abundance of YOY observed to numbers captured in the subsequent July electrofishing surveys. No counts occurred in May 2000 as relatively high flows throughout the period inhibited effective visual fry counts.

Data Analysis. - All statistical analyses were completed using the SAS 8.0 statistical software package (SAS Institute 1999). Statistical analyses methods varied with application, but included simple and multiple linear regression, non-linear regression, 
ANOVA, and non-parametric ANOVA and t-tests. Significance was set at the 0.05 level for all tests.

Simple linear regression was used to test significance of each sediment size and each habitat variable in relation to brook trout density and biomass between streams (stream was treatment unit). Habitat variables assessed included: average stream water depth, water depth complexity, average maximum pool depth, pool cover quality, number of pool habitats, pool and riffle area, pool to riffle ratio, average substrate particle size, substrate complexity, substrate embeddedness, amount of spawning substrate, amount of functioning and non-functioning LWD (subjective measures), and total amount of LWD. Testing within stream differences for adult and YOY densities for all habitat variables, in each stream, over two years yielded 29 significant differences in 616 separate statistical tests. Significant differences for habitat variables within streams were rare, with no more than might be expected by chance alone $(5 \%)$, and none that elicited any meaningful trend. Univariate regression analyses was not intended for the development of predictive models, but rather for identifying habitat variables significantly influencing brook trout population size. Separate analyses were completed for YOY, adult and total brook trout density and biomass.

Variables identified as significantly influencing brook trout abundance in the univariate analyses were then considered for use in a stepwise multiple linear regression (MLR) (Lanka et al. 1987). Stepwise multiple linear regression analysis was used to assess the importance of fine sediment in relation to other biotic and abiotic factors influencing brook trout abundance. Two to three significant variables were considered for inclusion in the MLR analysis only after their ecological significance was assessed. 
This assessment procedure was based upon field observation of the perceived important processes acting on brook trout populations in the study area. This technique implicitly reduces the chance of reporting erroneous findings based solely on statistical interpretation, but potentially increases the likelihood of researcher bias. Multiple linear regression analysis was completed for the summer and fall of 1999. Further analysis of the summer 2000 data was forgone as only one variable was found to be significant in univariate analyses. If two variables were significantly related, then only one was used in the MLR analysis to avoid parameter redundancy (Lanka et al. 1987).

Adult, YOY, and total brook trout density and biomass were analyzed separately in the MLR analysis. For adult and total brook trout density and biomass the three variables used in the MLR were average stream water depth, pool area, and stream gradient. For the MLR using YOY density and biomass as the dependent variable, average stream water depth and the percent fine sediment $<0.063 \mathrm{~mm}$ in non-redd substrate were used.

\section{Results}

Objective 1: assessment of brook trout spawning substrate composition. - Brook trout redds were commonly constructed in pool-riffle transitional zones. Redd composition averaged over all study streams for both years is displayed in Table 1. Substrate samples were pooled over all streams, as brook trout were of comparable size and streams were in similar geologic regions. Substrate less than $4.0 \mathrm{~mm}, 2.0 \mathrm{~mm}, 1.0 \mathrm{~mm}, 0.5 \mathrm{~mm}$, and $0.063 \mathrm{~mm}$ made up $22.5,13.4,7.2,3.9$ and $0.4 \%$ of brook trout redds respectively in fall 1998 (Table 2). For fall 1999 redds, the same sediment sizes comprised 25.5, 15.2, 9.2, 
5.4 and $0.7 \%$ respectively. Composition of non-redd samples are indicative of the substrate brook trout selected for spawning. Spawning areas contained 27.7, 18.2, 11.1, 7.0 and $0.9 \%$ sediment less than 4, 2, 1, 0.5 and $0.063 \mathrm{~mm}$ respectively in fall 1998 (Table 2). These same size classes represented 29.4, 19.2, 12.9, 8.4 and 1.3\% of spawning substrate composition measured in fall 1999. Average $d_{g}$ and $f_{i}$ values for redd and non-redd substrate in both years is presented in Table 3 .

Non-parametric randomized block ANOVA (Friedmans test) of substrate composition from redds and non-redds collected in fall 1998, showed adult brook trout (average $\mathrm{TL}=121 \mathrm{~mm})$ significantly $(\mathrm{p}=0.0134)$ reduced the amount of sediment $<2.0$ $\mathrm{mm}$ in the redd, as a result of the hydraulic construction process (Table 1). Use of truncated (removal of substrate $>32 \mathrm{~mm}$ ) substrate data yielded similar results. Coarsening of the substrate was also noted by higher observed $d_{g}$ and $f_{i}$ values in redds as compared to non-redds $\left(d_{g} \mathrm{p}=0.05\right.$ and $\left.f_{i} \mathrm{p}=0.04\right)$ (Table 3$)$. Analytical comparison was not conducted in fall 1999, as an error in record keeping prevented comparison of redds and their corresponding non-redd samples.

Comparison of percent composition data for substrate collected in fall 1998 and fall 1999 showed significant differences in amounts for two size classes (Table 4). Significant increases were noted for amounts of fine sediment less than $0.063 \mathrm{~mm}$ in both redds and non-redds between the two years $(\mathrm{p}=0.007$ and $\mathrm{p}=0.01$, respectively). Average percent composition of fine sediment $<0.063 \mathrm{~mm}$ was higher in fall 1999 redds $(0.7 \%)$ and non-redds (1.3\%), relative to levels measured in fall 1998 spawning substrate $($ redd $=0.4 \%$, non-redd $=0.9 \%)($ Table 1$)$. In general, there were increases in sediment amounts $<32 \mathrm{~mm}$ from 1998 to 1999 . Increases in sediment $<32 \mathrm{~mm}$ would lower the 
proportion of substrate $>32 \mathrm{~mm}$. This would result in a "perceived" significant decrease in sediment $>32 \mathrm{~mm}$ in redd substrate as was observed $(\mathrm{p}=0.02)$.

Objective 2: assessment of substrate composition influence on brook trout production. -

The per-capita birth rate (production) in year 1 averaged over all streams was 2.07 YOY/female $(95 \%$ CI = 0.84). Results from year $1(1998 / 1999)$ suggest brook trout production was a function of substrate permeability as measured by the $d_{g}$ (Figure 1). Production in year 1 was positively related to increasing redd substrate permeability $(\mathrm{p}=$ $\left.0.04, \mathrm{R}^{2}=0.7946\right)$. The same trend in production was evident for redd $f_{i}$ values, but only at the $\mathrm{p}=0.08$ significance level. No trends in production as a function of $d_{g}$ or $f_{i}$ were evident in year $2(1999 / 2000)$ analyses. Production in year 2 averaged over all streams was $1.83 \mathrm{YOY} / \mathrm{female}(95 \% \mathrm{CI}=2.03)$.

Objective 3 (part 1): determining fine sediment sizes influencing brook trout abundance.Brook trout were captured in all streams during the four electrofishing surveys. Average electrofishing removal efficiency of brook trout for all streams over the entire study was $97 \%($ range $=83-100 \%)$. Adult removal efficiency was 96\% (range $=83-100 \%)$ and YOY was $98 \%($ range $=94-100 \%)$. Significant differences in adult, YOY and total brook trout densities (Table 5) and biomass (Table 6) existed between streams in all four sample periods ( $\mathrm{p}<0.05)$. However, only one stream (Poca Run) differed significantly in the density of YOY in summer 2000 (Fishers LSD). Average adult brook trout length and weight over all streams for the entire study was $127 \mathrm{~mm}(\mathrm{n}=2817)$ and $21 \mathrm{gm}(\mathrm{n}=2817)$ respectively. Average YOY length and weight over all streams was $63 \mathrm{~mm}(\mathrm{n}=1428)$ 
and $3 \mathrm{gm}(\mathrm{n}=1428)$ respectively over the entire study. Average brook trout condition, over all streams, for fall 1998, summer 1999, fall 1999 and summer 2000 was $9.2 \mathrm{E}^{-6}, 9.8$ $\mathrm{E}^{-6}, 9.8 \mathrm{E}^{-6}$ and $10.4 \mathrm{E}^{-6}$, respectively. Young of the year brook trout were easily distinguished from adults in length-frequency analysis (Figure 2). Mature brook trout were generally $100 \mathrm{~mm}$ in length and $1+$ in age by the fall spawning period. For fall 1998, summer 1999, fall 1999 and summer 2000, YOY were considered to be under 88, 74,86 , and $85 \mathrm{~mm}$ in length for each sample period respectively. Inclusion of individuals between the designated lengths and $100 \mathrm{~mm}$ (maturity) as YOY was not done, as this would have included slow growing adults in YOY abundance estimates. Summer adult abundance in the first year of study was found to be positively related to YOY abundance in the previous fall $\left(\mathrm{p}<0.0001, \mathrm{R}^{2}=0.7238\right)$. No such relationship existed in the second year of the study.

Non-parametric ANOVA (Kruskal-Wallis Test) of all sediment sizes between streams in fall 1998 (year 1) found that sediment $<0.063 \mathrm{~mm}$ was the only size class with levels significantly different between streams (redds $p=0.003$, non-redds $p=0.01$ ). Analysis for fall 1999 (year 2) non-redd substrate revealed significant differences in amounts between streams for all sediment sizes below $1.0 \mathrm{~mm}(\mathrm{p}<0.05)$. Redd substrate in fall 1999 was significantly different between streams for only the $0.5 \mathrm{~mm}$ size class (p $=0.02)$.

Young of the year density and biomass were significantly related to measures of stream substrate in year 1 of the study (Table 7). For redd, substrate positive significant relation's were found between YOY density and biomass between streams, and percent less than data for several of the sediment size classes analyzed (percent $<32,<16,<0.5$, 
$<0.25 \mathrm{~mm}$ ). For redd substrate, the only significant inverse relation identified for both YOY density and biomass was for the percent fine sediment $<0.063 \mathrm{~mm}\left(\mathrm{p}=0.04, \mathrm{R}^{2}=\right.$ 0.7874 and $p=0.02, R^{2}=0.8652$, respectively) (Figures $3 \& 4$ ). Results were clearer for analysis of non-redd substrate particle sizes and YOY brook trout density and biomass. The only significant relationship for non-redds was for the percent fine sediment $<0.063$ mm (Figures $5 \& 6)\left(p=0.005, R^{2}=0.9489\right.$ and $p=0.007, R^{2}=0.9320$, respectively).

Statistical analysis using truncated percent composition data yielded similar, yet more concise results (Table 7). As the percentage of fine sediment $<0.063 \mathrm{~mm}$ in redds increased, the density of YOY brook trout decreased within the study streams $(p=0.03$, $\mathrm{R}^{2}=0.8138$ ). Young of the year biomass was negatively related to two size classes, the percent fine sediment $<0.125\left(\mathrm{p}=0.04, \mathrm{R}^{2}=0.7871\right)$ and $<0.063 \mathrm{~mm}\left(\mathrm{p}=0.01, \mathrm{R}^{2}=\right.$ 0.8977) in redds. The same relationship held true for the percent fine sediment $<0.063$ $\mathrm{mm}$ measured in non-redd substrate and YOY density and biomass $\left(\mathrm{p}=0.03, \mathrm{R}^{2}=\right.$ $0.8223 ; \mathrm{p}=0.03, \mathrm{R}^{2}=0.8280$, respectively).

Fall 1999 YOY density and biomass were still inverse functions of sediment < $0.063 \mathrm{~mm}$ measured the previous fall, however the trend was not statistically supported. Fifty-five $(\mathrm{p}=0.1)$ and $73 \%(\mathrm{p}=0.06)$ of the variation in fall 1999 YOY density between redds and non-redds respectively, was explained by sediment $<0.063 \mathrm{~mm}$ measured the previous fall. A large proportion of the variation in YOY biomass between redds $(\mathrm{p}=$ $\left.0.1, \mathrm{R}^{2}=0.5015\right)$ and non-redds $\left(\mathrm{p}=0.1, \mathrm{R}^{2}=0.6259\right)$ showed similar trends, but again the relationship was not statistically significant.

No significant negative relations between percent less than data for sediment collected in fall 1999 and YOY density and biomass existed in year 2 of the study. 
Interpretation was difficult, as a number of positive relationships were detected for numerous sediment sizes analyzed. Positive significant relationships between YOY density and biomass were found for sediment sizes as small as $<0.125 \mathrm{~mm}$ using both entire and truncated sediment data. As reported earlier, fine sediment $(<0.063 \mathrm{~mm})$ levels measured over all streams in year 2 of the study were significantly higher than measures in year 1 (Table 4). Consequently, these findings are reflected in regression analyses of fine sediment $(<0.063 \mathrm{~mm})$ and YOY density (Figure 7). Levels of fine sediment measured in year 2 of the study predominately fall within the asymptotic portion of the regression line making detection of a relationship impossible in year 2.

Visual fry (YOY) counts conducted in May 1999 were significantly related to relative numbers of YOY captured in the subsequent July 1999 electrofishing surveys ( $p$ $\left.=0.00002, \mathrm{R}^{2}=0.6839\right)$. Visual counts underestimated $(\sim 30 \%)$ the actual number of fry caught during the subsequent electrofishing survey. Despite underestimation, these data indicate that relative abundance of YOY during the July sample period were similar to numbers present in May, closer to the time of trout emergence. Estimates of YOY derived from visual counts showed a similar relationship to fine sediment $(<0.063 \mathrm{~mm})$. As was demonstrated for YOY abundance attained from electrofishing surveys, visual estimates of YOY declined with increasing levels of fine sediment $<0.063 \mathrm{~mm}$ measured at non-redd sites $\left(\mathrm{p}=0.008, \mathrm{R}^{2}=0.9063\right)$ in the first year of study. Truncated non-redd sediment data also showed a negative association to visually estimated YOY densities $\left(p=0.04, R^{2}=0.7830\right)$. Redd sediment data showed a negative influence on the number of YOY visually counted, but the relationship was not significant at the 0.05 level $(p=0.06)$. The relationship for truncated redd data was similar, yet again not 
significant $(\mathrm{p}=0.058)$. No fry counts were conducted in 2000 , as water conditions were not conducive for accurate visual assessment.

In addition to assessing fine sediment sizes influencing brook trout abundance, the influence sediment size classes had on substrate permeability was also assessed. As $d_{g}$ and $f_{i}$ values were not significantly different between the two years the data were combined for analysis of sediment sizes influencing substrate permeability (as measured by $d_{g}$ and $f_{i}$ ). The results revealed all size classes significantly influenced substrate permeability. The relationship between sediment size and $d_{g}$ and $f_{i}$ values was exponential for all sediment sizes analyzed. Positive relations were shown for larger sediment sizes, while $d_{g}$ and $f i$ values were inversely related to smaller sediment sizes (Table 8). Stepwise MLR revealed redd $d_{g}$ and $f_{i}$ (substrate permeability) were most negatively influenced by sediment between 0.5 and $1.0 \mathrm{~mm}$ (Table 8 ). The sediment size range explained $63 \%$ and $75 \%$ of the variation in $d g$ and $f i$ respectively. Results for nonredd substrate showed variation in $d_{g}$ was best explained by sediment between 0.5 and 1.0 $\mathrm{mm}(64 \%)$, and $\mathrm{f}_{\mathrm{i}}$ values by sediment $0.25-0.5 \mathrm{~mm}$ in range $(74 \%)$. These data suggest smaller fine sediment sizes $(0.25-1.0 \mathrm{~mm})$ most strongly influence substrate permeability, and perhaps brook trout survival during the intragravel period of development.

Objective 3 (part 2): determining fine sediment amounts influencing brook trout abundance. - As a significant negative relation to YOY abundance was identified for the percent fine sediment $<0.063 \mathrm{~mm}$, further assessment of threshold levels for this sediment size class was conducted. Near three-fold decreases in YOY abundance were noted as the amount of fine sediment $<0.063 \mathrm{~mm}$ increased from approximately 0.3 to 
$0.4 \%$ in redd substrate in the first year of study (Figures $3 \& 4$ ). The same magnitude of decrease in YOY abundance was noted in non-redd substrate samples at levels between 0.6 and $1.0 \%$ fine sediment $<0.063 \mathrm{~mm}$ (Figures $5 \& 6$ ). Therefore, the threshold limit for fine sediment $(<0.063 \mathrm{~mm})$ in spawning substrate, by which significant declines in YOY abundance occurred, is proposed to be between 0.6 and $1.0 \%$ of spawning bed composition.

Stream gradient was found to inversely influence fine sediment $(<0.063 \mathrm{~mm})$ amounts in brook trout redds in fall $1998\left(\mathrm{p}=0.04, \mathrm{R}^{2}=0.7763\right)$ (Figure 8$)$. In that same year, a similar relationship was demonstrated for fine sediment $<0.063 \mathrm{~mm}$ in non-redd substrate. Despite stream gradient explaining $67 \%$ of variation in fine sediment $(<0.063$ $\mathrm{mm})$ levels in non-redd substrate, the relationship was not significant $(\mathrm{p}=0.08)$. No trend was evident between stream gradient and fall 1999 (year 2) substrate samples.

Objective 4: Assessing fine sediment importance relative to other biotic and abiotic factors influencing brook trout abundance. - Six non-trout species were captured over all study streams, but only Mullenax Run contained every species. All streams except Little Low Place contained at least one other species than brook trout. Non-trout species captured include mottled sculpin (Cottus bairdi), blacknose dace (Rhinichthys atratulus), creek chubs, (Semotilus atromaculatus), mountain redbelly dace (Phoxinus oreas), white suckers (Catostomus commersoni), and fantail darters (Etheostoma flabellare). Total non-trout density and biomass were significantly $(\mathrm{p}<0.05)$ different between streams except in summer 2000 when no differences were detected. 
The number of different non-trout species (diversity) and their total density and biomass was negatively related to brook trout abundance. Adult and total brook trout density and biomass in all four sample periods (fall 1998, summer 1999, fall 1999, summer 2000) declined exponentially as non-trout fish diversity increased $(\mathrm{p}<0.05)$ (Figure 9). In contrast, YOY density and biomass was only significantly negatively related to non-trout species diversity in fall 1998. In addition, density of the three most common non-trout species (mottled sculpin, blacknose dace, creek chubs) in summer 1999 was inversely related to total brook trout density $\left(p=0.006, R^{2}=0.7967\right)$. This same trend was evident in the summer of $2000\left(\mathrm{p}=0.02, \mathrm{R}^{2}=0.6569\right)$. Total brook trout biomass followed the same significant pattern of decline in both years $(\mathrm{p}<0.05)$.

Water chemistry was considered good for all study streams during both baseflow and storm events (Table $9 \&$ Table 10). Measures of specific conductance and $\mathrm{pH}$ were both significantly $(\mathrm{p}<0.0001)$ higher in Sawmill Run than in the other study streams. No other significant differences in water chemistry existed between streams. At no time were measures of $\mathrm{pH}$ lower than 6.0 in either baseflow or storm event sampling. Inorganic Al was detected at low concentrations in both storm events, with highest levels measured at Sawmill Run $(0.086 \mathrm{mg} / \mathrm{L})$. Given the $\mathrm{pH}$ range and the low $\mathrm{Al}$ concentrations measured, it is unlikely that $\mathrm{Al}$ had any effect on brook trout survival in the streams studied.

Drought conditions were experienced over the entire region in summer 1999. Despite high air temperatures and low flow conditions, water temperature regimes were generally considered good for salmonid survival in all streams except Mullenax Run (Table 11). Summer daytime water temperature (9:00-21:00, June 1 - August 31, 1999) 
in Mullenax Run exceeded $20{ }^{\circ} \mathrm{C}$ for 162 non-consecutive hours (15\% of the time). No other stream exceeded $20{ }^{\circ} \mathrm{C}$ for any significant amount of time during the same period. Number of hours over $20{ }^{\circ} \mathrm{C}$ in Mullenax Run in summer 2000 was negligible under nondrought conditions. No water temperature data were collected at Sawmill Run in summer 2000 due to vandalism of the logger.

All study stream sample reaches were generally similar morphologically in statistical comparison to the entire study stream length. Comparison of average stream wetted width, maximum pool depth, pool cover rating, canopy cover and pool and riffle area between sample reaches (measured in summer 1999) and the entire study stream (basinwide assessment, summer 1999), showed only one significant difference. Average stream wetted width in the sample reaches of Mullenax Run was significantly less than average wetted stream width over the entire stream $(p=0.0002)$. Despite this difference in a single stream, the analysis is strong evidence to suggest the representative sample reaches selected in each study stream were similar morphologically to the rest of the stream.

Significant differences existed between streams for all habitat variables measured except, pool cover quality $(\mathrm{p}=0.2, \mathrm{~F}$-value $=1.38)$, water depth complexity $(\mathrm{p}=0.1, \mathrm{~F}$ value $=1.70)$ and volume of functioning LWD $(\mathrm{p}=0.1, \mathrm{~F}$-value $=1.62)$. Of the 22 habitat variables analyzed, those significantly influencing brook trout abundance in summer and fall 1999, and summer 2000 are listed in Table 12. They include: average stream water depth, average maximum pool depth, stream gradient, amount of spawning substrate, and pool area. Variables not significantly influencing brook trout abundance included: pool cover quality, water depth complexity, substrate complexity, riffle area, 
pool to riffle ratio, vegetative canopy cover, substrate embeddedness and all measures of LWD.

Average water depth, average maximum pool depth and the amount of spawning substrate were positively related to adult and total brook trout density and biomass in summer 1999 (year 1) (Figures 10, 11, 12). No habitat variables showed significant relation to YOY density in summer 1999. Total brook trout abundance was also determined to be a function of stream gradient in summer 1999, with total brook trout density and biomass increasing with stream gradient $\left(p=0.01, R^{2}=0.7475 ; p=0.007, R^{2}\right.$ $=0.7951$, respectively) (Figure 13). Adult biomass showed the same trend $\left(p=0.04, R^{2}\right.$ $=0.5845)$, but the relationship was not significant for density $(\mathrm{p}=0.054)$.

Water levels remained at or near drought conditions into fall 1999. Average water depth, average maximum pool depth, amount of spawning substrate and the percentage of pool area measured in the summer were positively related to fall 1999 adult and total brook trout density and biomass (Table 12). As summer water levels increased, the density of adults and total brook trout increased (average water depth $\mathrm{p}=0.007, \mathrm{R}^{2}=$ 0.7889; $\mathrm{p}<0.0001, \mathrm{R}^{2}=0.9931$; respectively; average maximum pool depth $=0.007, \mathrm{R}^{2}$ $=0.7952 ; \mathrm{p}=0.04, \mathrm{R}^{2}=0.5746$, respectively). Adult brook trout density and biomass increased as the amount of spawning substrate increased $\left(p=0.03, R^{2}=0.6052 ; p=0.04\right.$, $\mathrm{R}^{2}=0.5721$, respectively). Total brook trout density and biomass followed the same pattern $\left(p=0.006, R^{2}=0.7960 ; p=0.03, R^{2}=0.6159\right.$, respectively). Pool area, not significant in summer 1999, was significantly related to adult and total brook trout abundance in fall 1999. Adult density and biomass were positively related to the amount of pool area measured in summer $1999\left(p=0.02, R^{2}=0.6514 ; p=0.02, R^{2}=0.6856\right)$ 
(Figure 14). Total brook trout density was not, but total brook trout biomass was a function of pool area $\left(\mathrm{p}=0.02, \mathrm{R}^{2}=0.6713\right)$. Stream gradient was not significant for fall 1999 brook trout densities. Young of the year abundance in fall 1999 was again not a function of any habitat variable measured earlier in the summer.

Stream gradient was the only significant variable found to be influencing brook trout abundance in summer 2000 (year 2) analyses. Gradient had a positive significant influence on YOY and total brook trout density $\left(\mathrm{p}=0.04, \mathrm{R}^{2}=0.6399 ; \mathrm{p}=0.02, \mathrm{R}^{2}=\right.$ 0.8759, respectively) (Table 12). Biomass for YOY followed the same trend $(\mathrm{p}=0.02$, $\left.\mathrm{R}^{2}=0.6540\right)$ but, total brook trout biomass was not significant $(\mathrm{p}=0.06)$. No other habitat variables were significantly related to either YOY or adult brook trout abundance.

Variables influencing brook trout abundance independently in summer 1999 and fall 1999 were identified above. They include average stream water depth, average maximum pool depth, pool area, stream gradient, amount of spawning substrate, nontrout species diversity, and percent fine sediment $<0.063 \mathrm{~mm}$ in redds and non-redds. Interactions were noted between several of the aforementioned parameters. Therefore, some variables were excluded from use in the MLR analysis to avoid parameter redundancy. Average maximum pool depth was significantly related to average stream water depth $(\mathrm{p}=0.04)$, with the latter being used in the MLR. Non-trout species diversity and the amount of spawning substrate were not utilized in further analyses, as both were significantly related to average stream water depth $(p=0.005$ and $p=0.005$, respectively). The percentage of fine sediment $<0.063 \mathrm{~mm}$ in non-redds was used in subsequent analysis instead of fine sediment levels measured in redds. The aforementioned is likely a better measure of substrate conditions during egg 
development. Furthermore, substrate collected from non-redds $\left(\mathrm{R}^{2}=0.9489\right)$ explained more of the variation in YOY density than did redd substrate $\left(\mathrm{R}^{2}=0.7874\right)$.

The remaining variables (average stream water depth, stream gradient, pool area) exhibited no collinearity, and were therefore used in the MLR analysis for adults and total brook trout abundance. Stream gradient and fine sediment were related (Figure 8) making inclusion of both in the MLR for YOY brook trout unnecessary. Fine sediment was chosen for inclusion to the model, as stream gradient was not related to YOY density and biomass (Table 12). The MLR using YOY density and biomass as the dependent variable used average stream water depth and the percent fine sediment $<0.063 \mathrm{~mm}$ in non-redd substrate.

Stepwise MLR analysis of adult brook trout density for summer 1999 revealed that average stream water depth was the only variable significant in the model $(p=0.01)$ (Table 13), accounting for $73 \%$ of variation in adult density between streams. Results differed when modeling adult brook trout biomass, whereby both stream gradient and pool area were significant $(\mathrm{p}=0.005)$, accounting for $93 \%$ of the variation in adult biomass. However, stream gradient alone explained $77 \%$ of that variation.

Analysis of YOY density and biomass for summer 1999 found only one of the two variables included in the model to be significantly influencing YOY population size between streams. Fine sediment $<0.063 \mathrm{~mm}$ in the spawning substrate explained $95 \%$ of the variation in YOY density $(\mathrm{p}=0.005)$. Use of YOY biomass as the dependent variable in the same model found fine sediment again was the only significant variable, explaining $93 \%$ of variation in YOY biomass $(\mathrm{p}=0.007)$. 
Both average water depth and stream gradient accounted for $93 \%$ of the variation in total summer 1999 brook trout density $(\mathrm{p}=0.004)$, with average water depth solely explaining $85 \%$ of that variation. As was the case in the analysis of adult biomass, analysis using total brook trout biomass showed average stream gradient and pool area were both significant $(\mathrm{p}=0.003)$, with $80 \%$ of variation in total brook trout biomass explained by stream gradient.

Modeling average summer water depth, pool area and stream gradient for fall 1999 brook trout densities and biomass, I found average stream water depth to be the only variable significantly explaining a large portion of variation in adult and total brook trout density and biomass. Average stream water depth explained $79 \%$ and $99 \%$ of differences in adult and total brook trout density between streams, respectively (adult: $\mathrm{p}=$ 0.007 total: and $\mathrm{p}<0.0001)$. Average stream water depth accounted for $78 \%$ and $83 \%$ of the variation in adult and total brook trout biomass between streams (adult: $p=0.008$ and total: $\mathrm{p}=0.004)$.

Young of the year MLR analysis for fall 1999 found fine sediment $<0.063 \mathrm{~mm}$ to be more important than average summer water depths in explaining variation in YOY abundance. Fine sediment $<0.063 \mathrm{~mm}$ accounted for $73 \%$ and $63 \%$ of variation in YOY density and biomass respectively. The model was however, not significant for either at the 0.05 level ( $\mathrm{p}=0.06, \mathrm{p}=0.1$, respectively).

\section{Discussion}

Objective 1: assessment of brook trout spawning substrate composition. - The first research objective was to characterize the substrate composition utilized by brook trout (< 
$250 \mathrm{~mm}$ TL) in eastern forested headwater streams. Substrate material used was predominately $<32 \mathrm{~mm}$ in size, with approximately $25 \%$ being $<4.0 \mathrm{~mm}$ (Table 2 ). As particles $<4.0 \mathrm{~mm}$ comprised a large percentage the spawning substrate in both years, it is suggested the percent fine sediment $<4.0 \mathrm{~mm}$ may not adequately define "fine sediment" as it pertains to the smaller brook trout. Therefore, sediment sizes smaller than $4.0 \mathrm{~mm}$ should be considered for establishing fine sediment criteria applied to brook found in these systems.

Brook trout coarsened the redd substrate during the construction process. Hydraulic cleaning increased redd substrate permeability, and was evident by higher $d_{g}$ and $f_{i}$ values relative to non-redd substrate (Table 3). Adult brook trout (mean TL $=121$ $\mathrm{mm}$ ) significantly reduced the amount of fine sediment $<2.0 \mathrm{~mm}$ from the redd tailspill and egg pocket (Table 1). Comparable findings were reported by Young et al. (1989) showing brook trout $(<250 \mathrm{~mm})$ significantly reduced the amount of fine sediment $<1.7$ $\mathrm{mm}$ from the egg pocket. Similar findings for other salmonids have been reported (McNeil and Ahnell 1964, Platts et al. 1979, Everest et al. 1987, Grost et al. 1991).

The scoop method employed in this study for substrate collection was at least as good as the shovel method (Grost et al. 1991) for sampling small substrate patches. The scoop worked well for collecting substrate smaller than the scoop mouth $(14.7 \mathrm{~cm})$. Although not statistically validated, the upward turned sides of the scoop potentially aided in retention of fine sediment that may have otherwise been lost in suspension during collection. 
Objective 2: assessment of substrate composition influence on brook trout production. Objective two of this study was to ascertain if substrate composition was influencing brook trout production (per-capita birth rate) within the study streams, as was suggested by the USFS (Angradi and Vinson 1996, T. Cain, USFS Monongahela National Forest, personal communication). Additions of fine sediment decrease substrate permeability (Platts et al. 1979, Reiser and White 1988, Argent and Flebbe 1999) and salmonid survival during the intragravel period (Cooper 1965, Chapman 1988, Lotspeich and Everest 1981, MacCrimmon and Gots 1986, Scrivener and Brownlee 1989). Results suggest substrate permeability, as measured by the $d_{g}$ and $f_{i}$, did inversely influence brook trout production in the first year of study (Figure 1). This would suggest substrate composition was influencing brook trout production in that year as suggested by the USFS.

Question arises as to why the trend was not evident in year 2 of the study, as $d_{g}$ and $f_{i}$ values for redds and non-redds were not significantly different between years. The lack of relation in year 2 was surmised to be a factor of drought conditions (experienced over much of the Northeast in 1999, NOAA 1999) overpowering and/or hindering our ability to detect relationships between brook trout production and streambed composition. Precipitation for the study area between January 1 and August 31, 1999 was $20.6 \mathrm{~cm}$ below the normal precipitation amounts for that time period (30-year average in Elkins, $\mathrm{WV}=79.2 \mathrm{~cm})$. Consequently, all study streams experienced low flow conditions throughout summer and fall 1999. As a result, there were significantly fewer adult brook trout $(58 \%)(\mathrm{p}=0.007)$, of lower body condition $(3 \%)(\mathrm{p}<0.0001)$ in all study streams during the fall 1999 spawning period, as compared to the previous fall when annual 
precipitation was near normal (NOAA/NCDC 1999). With presumably fewer adult brook trout (of lower body condition) spawning in fall 1999, the resultant production of YOY in year 2 (2000) was $67 \%$ lower than the previous year. Use of raw total number of fish captured, instead of density, yielded similar results. Comparing between streams, YOY brook abundance in the post-drought period (summer 2000) was only significantly different in one of the seven study streams (Poca Run, Fishers LSD). Consequently, detecting differences in YOY abundance between streams, attributed to substrate composition, was hindered in year 2 (1999/2000). In combination, the results suggest the long-term impact of the 1999 drought either over-powered and/or weakened our ability to statistically detect a relationship between substrate composition and brook trout production.

Another indication sediment may have been influencing YOY abundance in $1998 / 1999$ is drawn from the significant relation between visual fry counts and subsequent electrofishing surveys. The data suggest YOY population size was set prior to the visual counts, and closer to the intragravel period when fine sediment may have been influencing embryo survival. The finding is supporting, but not conclusive evidence, as prey of suitable size or space (Mason and Chapman 1965, Chapman 1966, Egglishaw 1967, Jonsson et al 1998) may have been limited.

Objective 3 (part 1): determining fine sediment sizes influencing brook trout abundance.The third objective was to identify a critical fine sediment size class driving the observed relation between brook trout production and substrate composition. A two-layer approach was used to establish a critical fine sediment size negatively influencing brook 
trout abundance. The first assessed sediment sizes negatively influencing substrate permeability, while the second evaluated sediment sizes directly influencing YOY abundance.

Analyses of fine sediment sizes for both redds and non-redds in fall 1998 and 1999 combined, showed $d_{g}$ and $f_{i}$ values (substrate permeability) were negatively related to fine sediment (Table 8) (Platts et al. 1979, Everest et al. 1987, Magee et al. 1996). Multiple linear regression analyses determined fine sediment sizes between 0.25 and 1.0 mm explained the greatest proportion of variation in both $d_{g}$ and $f_{I}$ values. Magee et al. (1996) reported sediment $<0.85 \mathrm{~mm}$ accounted for the largest proportion of variation $\left(\mathrm{R}^{2}\right.$ $=0.75)$ in substrate $f_{i}$ values. This size class falls within the range $(0.25-1.0 \mathrm{~mm})$ identified in this study, further bolstering the validity of our conclusions.

Results above suggest levels of fine sediment below $1.0 \mathrm{~mm}$ are likely most detrimental to salmonid survival and emergence in the systems studied, through impact upon substrate permeability. Both laboratory and field studies conducted by other researchers have arrived at similar conclusions. Tappel and Bjornn (1983) found that steelhead survival to emergence in laboratory troughs was best related $\left(R^{2}=0.86\right)$ to fine sediment less than $1.7,0.85$ and $0.42 \mathrm{~mm}$ in size. In a field study, coho salmon survival to emergence was significantly reduced as the percentage of fines $<0.85 \mathrm{~mm}$ increased in spawning beds (Cederholm et al. 1980). Both investigators demonstrated sediment sizes below $1.0 \mathrm{~mm}$ were generally, detrimental to salmonid survival as is suggested by the negative relation of substrate permeability and sediment $<1.0 \mathrm{~mm}$ found in this study. The observed relationship between YOY brook trout abundance and sediment $<$ $0.063 \mathrm{~mm}$ in year 1 (Figures 3-6), suggests it is the finest sediment having ecological 
bearing on YOY abundance. However, the results are not definitive, and sediment sizes larger than $0.063 \mathrm{~mm}$ may have been influential in the first year of this study. Testing for significant differences in amounts of all sediment size classes between streams revealed that in year 1 , only the amount of sediment $<0.063 \mathrm{~mm}$ was statistically different between streams (redds $p=0.003$, non-redds $p=0.01$ ). Therefore, the possibility exists that variation between streams in sediment levels for other sizes were not large enough, thus diminishing our ability to detect a relationship between YOY abundance and other sediment sizes.

Despite these interpretive limitations, there is support for fine sediment $<0.063$ $\mathrm{mm}$ as a crucial sediment size limiting brook trout abundance through increased mortality during the intragravel period, or through food web based effects. Peterson and Metcalfe (1981) demonstrated emergence of Atlantic salmon fry was reduced to a greater extent by sediment $0.06-0.5 \mathrm{~mm}$ in size, than by coarser sediment treatments $(0.5-2.3 \mathrm{~mm})$. Laboratory experiments by Reiser and White (1988) showed sediment $<0.84 \mathrm{~mm}$ decreased rainbow trout and chinook salmon embryo survival to a greater extent than sediment $0.84-4.6 \mathrm{~mm}$. Our results possibly reflect the more harmful influence smaller fine sediment $(<0.063 \mathrm{~mm})$ has upon salmonid embryo and fry survival.

Sediment production is positively related to road density in a watershed (Cederholm et al. 1980). Road surfaces are a chronic source of sediment especially of the smaller grain sizes (Reid et al. 1981, Reid and Dunne 1984, Shepard et al. 1984, Everest et al. 1987). Grayson et al. (1993) reported that suspended sediment constituted two thirds of the sediment produced from roadways in a forested watershed. With roads as the obvious source of fine sediment in the study area, it is reasonable to speculate excess 
fine sediment is potentially entering the study streams. Sediment data collected in this study, between fall 1998 and 1999, showed significant increases in levels of fine sediment $<0.063 \mathrm{~mm}$ between the two years (Table 4 ), suggesting roads in the study area were producing fine sediment in excess of natural production. This excess fine sediment $(<0.063 \mathrm{~mm})$ may therefore be the sediment size driving the relationship observed for YOY brook trout abundance in the first year of this study.

Finer particles are more easily transported within stream systems (Murphy and Meehan 1991). Brown trout redds were found to accumulate proportionally more fine sediment $(0.85-0.42 \mathrm{~mm})$ during the incubation period, than courser particles (Grost et al. 1991). Therefore, the observed relation between sediment $<0.063 \mathrm{~mm}$ and YOY abundance may be a function of that size class accumulating within the redd substrate at higher rates, further impacting embryonic survival.

Additionally, smaller grain sizes penetrate deeper into the substrate relative to larger particles. The laboratory work of Beschta and Jackson (1979) showed that fine sediment (median grain size $0.2 \mathrm{~mm}$ ) had a higher intrusion rate and penetrated farther into the gravel mixture than did larger sediment particles (median grain size of $0.5 \mathrm{~mm}$ ). Extrapolated to natural conditions, the results suggest finer grains are those potentially entering the redd first, and at higher depositional rates, further aiding the explanation to the observed relationship between sediment $<0.063 \mathrm{~mm}$ and YOY abundance.

In summary of the evidence supporting sediment $<0.063 \mathrm{~mm}$ as the sediment size limiting brook trout population size, it has been demonstrated that smaller sediment sizes are more harmful to the early life stage survival of salmonids. Sediment produced from roads is of the finer grain sizes and would therefore potentially be in excess of natural 
levels. Finer grained sediment particles are more readily transported, thus their depositional rate is higher and penetration deeper into the substrate allowing for filling of the substrate interstices.

A relationship between YOY density and biomass in fall 1999, and sediment $<$ $0.063 \mathrm{~mm}$ measured in non-redds in fall 1998 was also evident. However, the trend was not significant (density: $\mathrm{p}=0.06$; biomass $\mathrm{p}=0.1$ ) and weaker than found earlier in summer 1999 (density: $\mathrm{p}=0.005, \mathrm{R}^{2}=0.9489$; biomass: $\mathrm{p}=0.007, \mathrm{R}^{2}=.0 .9320$ ). Despite lack of statistical significance, sediment $<0.063 \mathrm{~mm}$ explained $73 \%$ and $63 \%$ of variation in fall 1999 YOY density. The weakened fall relationship is probably a result of other sources of mortality (e.g. drought) acting upon YOY survival over the summer period.

Year 2 sediment data did not show the same relationship between fine sediment $(<0.063 \mathrm{~mm})$ and YOY abundance as demonstrated in year 1. Again, the lack of relation is believed to be a consequence of the 1999 drought over-powering and/or hindering our ability to detect a relationship. Additionally, average fine sediment $(<0.063 \mathrm{~mm})$ levels over all streams were significantly higher in year 2 relative to year 1, in both redds and non-redds ( $\mathrm{p}=0.007, \mathrm{p}=0.01$, respectively) (Table 4). Consequently, fine sediment levels were in the asymptotic portion of levels measured in year 1 of the study (Figure 7). This would have made detection of a trend in YOY brook trout abundance to fine sediment $(<0.063 \mathrm{~mm})$ difficult if not impossible in year 2 .

Combining the results of sediment sizes directly influencing YOY abundance, with those evaluating sizes most influencing substrate permeability (and presumably intragravel survival), allows for further evaluation of critical fine sediment sizes most 
influencing wild brook trout populations. Although no definitive size class and amount could be accurately identified, interpretation of the results does suggest a critical size range of sediment potentially limiting brook trout population size. At a minimum the data suggest fine sediment $<0.063 \mathrm{~mm}$ is influencing brook trout abundance in the streams studied. The upper limit is unclear, but significant negative reductions detected in substrate permeability, caused by sediment between $0.25 \mathrm{~mm}$ and $1.0 \mathrm{~mm}$, does offer an upper size limit. These results would therefore suggest the critical fine sediment size, as it pertains to the brook trout in this study, is between $0.063 \mathrm{~mm}$ and $1.0 \mathrm{~mm}$ in size. These sediment sizes are potentially limiting brook trout abundance in the streams studied, through presumably decreased intragravel survival or food web impacts.

Objective 3 (part 2): determining fine sediment amounts influencing brook trout abundance. - The second facet of this two-part third objective, included identifying a threshold amount of fine sediment, whereby a significant decline in brook trout abundance occurred. Drawing from the significant simple linear regression analyses using sediment $<0.063 \mathrm{~mm}$ (Figures 3-6), we see a near three-fold decrease in YOY density and biomass as fine sediment $(<0.063 \mathrm{~mm})$ increases from 0.3 to $0.4 \%$ in redds, and from 0.6 to $1.0 \%$ in non-redds. Non-redd substrate is potentially a better measure of spawning bed conditions during the intragravel period of salmonid development.

Therefore, based on these data, it is proposed that fine sediment $(<0.063 \mathrm{~mm})$ should not exceed $0.6-1.0 \%$ of the spawning bed substrate, or possible negative impacts to brook trout populations could be incurred. 
The amount of fine sediment $<0.063 \mathrm{~mm}$ measured in this study was extremely small, generally comprising $<1 \%$ of redd substrate and $<2 \%$ of non-redd substrate (Table 2). Few studies have reported on such a small sediment size in natural systems, making validation of our findings difficult. However, drawing indirectly from the results of Maret et al. (1993) (substrate sizes similar to this study), reporting sediment $<0.063$ mm comprised $<2 \%$ of samples by weight in a "sediment impacted" Idaho stream. As the authors characterized their study stream as "sediment impacted", it suggests streams in this study were in similar condition as levels of fine sediment were comparable.

A number of laboratory studies have determined fine sediment amounts detrimental to salmonid egg survival and emergence success (Philips et al. 1975, Peterson and Metcalfe 1981, Reiser and White 1988). Hausle and Coble (1976) reported brook trout survival to emergence began to decline as percentages of fine sediment $(2.0 \mathrm{~mm})$ exceeded $20 \%$. The smallest fine sediment used in their laboratory study was $2.0 \mathrm{~mm}$. Thus, the $20 \%$ threshold is likely an overestimate of critical sediment amounts, as smaller size classes are inherently present in natural systems. Average levels of sediment $<2.0$ mm measured in this study were somewhat below the $20 \%$ threshold (Table 2). This suggests based on the work of Hausle and Coble (1976), fine sediment levels may have been at levels high enough to negatively impact brook trout survival. Argent and Flebbe (1999) reported brook trout fry survival at $25 \%$ fines $(0.43 .0 .85 \mathrm{~mm})$ was half that of survival at $0 \%$ fines in laboratory study. Survival at fine sediment levels of $0 \%$ and $5 \%$ was significantly higher than survival at $20 \%$ and $25 \%$. Conceivably the critical fine sediment level for particles $<0.85 \mathrm{~mm}$ is between $5 \%$ and $20 \%$. This study did not separate fines of $0.85 \mathrm{~mm}$, however percent composition of fine sediment $<1.0 \mathrm{~mm}$ 
(Table 2) does fall in the 5\% to $20 \%$ range identified by Argent and Flebbe (1999). In general, sediment levels measured in this study (Table $1 \& 2$ ) appear to be at or slightly below amounts deemed detrimental to salmonid survival by other investigators.

In natural systems the effect of fine sediment upon stream inhabitants is mitigated by a number of environmental and behavioral mechanisms (Bams 1969, Everest et al. 1987, Young et al. 1989, Dolloff et al. 1994). Steeper gradient streams have been shown to more effectively remove fine sediment from the system (McNeil 1969, Adams and Beschta 1980, Shepard et al. 1984, Everest et al. 1987). Stream gradient in this study was related to lower levels of fine sediment $(<0.063 \mathrm{~mm})$ in redds in fall 1998, (Figure 8) suggesting less deposition of fine sediment in higher gradient streams. The findings suggest impacts of increased sedimentation may potentially be mitigated in steeper gradient stream systems.

Trends in fine sediment, as related to stream gradient observed in year 1, were not evident in year 2. I theorize for stream gradient to be a factor in the removal of fine sediment, there must be adequate water flows within the system to remove small particulate build-up from the streambed. Water flows from June through October were extremely low for extended periods due to drought conditions, with no exceptionally large runoff events (exceeding bankfull, personal observation). Researchers have demonstrated high flows coarsen streambed substrate (McNeil and Ahnell 1964, Scrivener and Brownlee 1989, Dolloff et al. 1994). Meehan and Swanston (1977) stated that fine sediment "tends to increase" in stream systems "not experiencing high flows". Everest et al. (1987) speculated that in systems where persistent sediment sources existed (e.g. roads), fine sediment potentially increases over time, building to levels requiring 
greater time for removal. Flows with a magnitude large enough to scour the streambed material (Adams and Beschta 1980), and in-turn remove fine particulates, are not believed to have occurred in 1999. Without sufficient hydraulic force to remove fine sediment during 1999, there was a net gain of sediment over all the systems as compared to 1998 (Table 1).

Positive relation of YOY density and biomass to two larger sediment sizes (32 and $16 \mathrm{~mm}$ ) was noted (Table 7). Studying coho salmon in Washington, Tagart (1976) found sediment sizes $>3.35 \mathrm{~mm}$ to be positively correlated to survival to emergence. This phenomenon is conceivably a consequence of using percentages as a measure. Particles in a sample are inter-correlated thus, increases in larger sediment classes would result in declines in measures of smaller size classes and vice-versa.

The more robust relationships seen for non-redd substrate and YOY abundance (Figure $5 \& 6$ ) is likely a factor of increased variation in redd substrate composition as a result of removal of fine sediment from the redd during construction. Percent fine sediment $<0.063 \mathrm{~mm}$ was more variable in redd samples $(\mathrm{CV}=66.2)$ than in non-redd samples $(\mathrm{CV}=57.0)$. Researchers and managers should therefore consider collecting substrate samples from the surrounding substrate (non-redd samples), as these measures may better represent the background substrate conditions, and in-turn the redd environment during the incubation period.

Objective 4: Assessing fine sediment importance relative to other biotic and abiotic factors influencing brook trout abundance. - The final objective of this study was to identify factors, other than fine sediment, influencing brook trout abundance, and to 
assess the relative importance of fine sediment in relation to these other variables. This task has proven difficult in application to wild fish populations (Iwamoto et al. 1978, Everest et al. 1987).

Number of non-trout species abundance and biomass was demonstrated to negatively influence brook trout density and biomass (Figure 9). Salmonid abundance has been reported to decline as non-trout species diversity increases (Bowlby and Roff 1986). For this study we suggest the observed relationship between brook trout abundance and non-trout species diversity was a factor of habitat preference. Non-trout species diversity declined with increasing average water depth and stream gradient $(\mathrm{p}=$ $0.005, \mathrm{p}=0.006$, respectively), while the opposite was true for brook trout abundance (Figures $10 \& 13$ ). The association suggests the relation between brook trout abundance and non-trout species diversity was mirroring underlying habitat preferences of the species.

Water quality measured during both baseflow and storm event sampling was generally good for salmonid survival. This would suggest brook trout abundance was not largely influenced by differences in water quality, and perhaps more through difference in habitat quality. Summer and fall 1999 analysis revealed water depth (average stream and maximum pool depth) to be positively related to adult, and total brook trout abundance (Figures $10 \& 11$ ), a relationship demonstrated for other salmonids (Stewart 1970, Kennedy and Strange 1982, Scarnecchia and Bergersen 1987, Titus and Mosegaard 1992). In this study we contend the relationship to water depth was governed by stream discharge. Brook trout abundance was not a function of stream discharge directly, but the lack of relation may be an artifact of measuring discharge only once a year. Average 
stream water depth and average maximum pool depth combined for both years, were positively related to stream discharge $(\mathrm{p}=0.0004, \mathrm{p}=0.0005$, respectively). From these data I suggest stream discharge was the underlying force governing the observed relationship between adult and total trout abundance, and both average stream water depth and average maximum pool depth.

Increasing stream gradient has been demonstrated to negatively influence salmonid abundance (Chisholm and Hubert 1986, Lanka et al. 1987, Kozel et al. 1989). The relationship is believed to be a function of lower habitat quality in headwater systems that often have fewer pool habitats of lower quality, and larger hydrologic extremes (Lanka et al. 1987, Kozel et al. 1989). The contradictory results of this study are potentially a function of the small sample size over a limited geographic area. The results showed a trend towards deeper average water depths with increasing stream gradient. Although the relation was not significant $(\mathrm{p}=0.07)$, I feel that the explanation of nearly $50 \%$ of the variation in water depth accounted for by stream gradient justifies our conclusion. As trout abundance was positively related to deeper water depths, it is suggested the observed positive relation in trout abundance to stream gradient may potentially have been a function of the influence stream gradient had upon water depth.

A number of researchers have shown YOY salmonid abundance to be a factor of the amount of spawning substrate (Cunjak and Green 1983, Beard and Carline 1991, Bozek and Rahel 1991b). Young of the year density in this study was not a function of spawning substrate, but adult brook trout density was in both summer and fall 1999 (Figure 12). This relationship is thought to driven by stream water depth. Streams with greater average water depths had more area of spawning gravel $(\mathrm{p}=0.005)$, and contained 
higher densities of adult brook trout. As the amount of spawning substrate significantly increased with greater average stream water depth, the observed relationship between spawning substrate and adult density may have been an underlying function of water depth.

For measures of pool cover quality, water depth complexity and volume of functioning LWD, differences between streams were not significant. Brook trout abundance was not related to any of the three variables. Consequently, the lack of relation to brook trout abundance for the three varibles may possibly be attributed to low test power between streams.

Stream salmonid carrying capacity may be limited by summer low flows (Elliot 1993, Lestelle et al. 1993), specifically by the amount of residual pool habitat used as refuge (Kraft 1972, Elliot and Hurley 1998 in Elliot 2000, Huntingford et al. 1999). Only in fall 1999 (after drought had been in effect all year) does a relationship develop between adult brook trout abundance and pool area (Figure 14). As pool area was positively related to stream discharge $(\mathrm{p}=0.007)$, it suggests stream discharge was the underlying governing force influencing brook trout abundance.

Multiple linear regression analysis for summer 1999 revealed average stream water depth explained the greatest proportion of variation in adult and total brook trout densities. However, results of the MLR analysis using biomass, determined stream slope to be most influential. The conflicting results are probably a function of higher variability in measures of fish biomass than density (Platts and Nelson 1988). This disparity was not evident in fall 1999 analysis, when both brook trout density and biomass were most influenced by summer average water depths (Hunt 1979). As average 
stream water depth was significantly related to stream discharge $(\mathrm{p}=0.007)$, this would again suggest summer stream discharge was the underlying factor influencing adult and total brook trout abundance in the first year of study.

Multiple linear regression analysis using YOY abundance strongly suggests fine sediment $<0.063 \mathrm{~mm}$ was of principal influence on YOY abundance, presumably through decreased intragravel survival or food web impacts. The inference is furthered by the lack of relation to other variables known to influence YOY abundance (spawning substrate, water depth). The relationship between fine sediment and fall 1999 YOY abundance is weaker than found in the summer analysis, suggesting increased summer mortality. Drought conditions over the period are a likely explanation for the weakened relationship.

Summary. - A large portion of brook trout spawning substrate $(\sim 27 \%)$ was comprised of particles $4.0 \mathrm{~mm}$ and smaller. This suggests $4.0 \mathrm{~mm}$ perhaps is a relatively large substrate size for use as a criteria defining "fine sediment" in application to the smaller brook trout. Therefore, sediment sizes smaller than $4.0 \mathrm{~mm}$ may better represent "fine sediment" as it pertains to brook trout inhabiting headwater systems.

Comparison of sediment levels deemed critical by other researchers (Hausle and Coble 1976, Argent and Flebbe 1999), suggest sediment amounts are near critical levels in the streams studied. Sediment sizes between 0.25 and $1.0 \mathrm{~mm}$ were shown to strongly influence substrate permeability and potentially brook trout survival. Additionally, results showed YOY abundance in the first year of the study was significantly influenced by the amount of fine sediment $<0.063 \mathrm{~mm}$. In combination, the above results suggest 
the crucial fine sediment size, as it applies to brook trout in these systems, is between $0.063-1.0 \mathrm{~mm}$ in size. The data further suggest fine sediment $(<0.063 \mathrm{~mm})$ should not exceed $0.6-1.0 \%$ of brook trout spawning substrate, or negative population impacts may be incurred.

The MLR analyses suggest YOY abundance was primarily influenced by fine sediment $(0.063 \mathrm{~mm})$ in the first year of the study. However, the significant relationship between fine sediment and stream gradient complicates inferences drawn about the importance of fine sediment. Intercorrelation between these variables prevented solid conclusion as to which variable, fine sediment or stream gradient, carried the greatest influential weight in governing YOY abundance. However, the lack of relation of YOY abundance to stream gradient in year 1 of the study, would suggest that fine sediment influences were of greater importance than gradient.

The results indicate brook trout abundance within the streams studied was a factor of both substrate composition and stream discharge during periods of normal stream flow (stream flow based on precipitation data). Young of the year brook trout abundance is suggested to be a factor of fine sediment levels in years of normal stream flow, while adult brook trout abundance was principally a function of stream discharge in the first year of study. Additionally, the significant relationship between summer adult brook trout abundance and YOY abundance the previous fall suggests adult abundance was potentially influenced by fine sediment impacts on juvenile recruitment. Therefore, managers should realize fine sediment has potential implications for managing adult brook trout populations in headwater stream systems. 
Table 1. Mean percent composition for redd and non-redd substrate collected in both years. Sediment sizes marked with an asterix (*) indicate a significant difference in amounts between redds and non-redds in fall 1998 (95\% CI below mean).

\begin{tabular}{|c|c|c|c|c|c|c|c|c|c|c|c|}
\hline \multirow{4}{*}{$\begin{array}{l}\text { Sample } \\
\text { location }\end{array}$} & \multicolumn{11}{|c|}{ Sieve mesh size $(\mathrm{mm})$} \\
\hline & \multirow{3}{*}{$>32$} & \multirow{3}{*}{$16-<32$} & \multirow{3}{*}{$8-<16$} & \multirow{3}{*}{$4-<8$} & \multirow{3}{*}{$2-<4$} & \multicolumn{3}{|c|}{ Fall 1998} & \multirow{3}{*}{$\begin{array}{l}0.125- \\
<0.25^{*}\end{array}$} & \multirow{3}{*}{$\begin{array}{l}0.063- \\
<0.125^{*}\end{array}$} & \multirow{3}{*}{$<0.063 *$} \\
\hline & & & & & & $1-<2 *$ & $0.5-<1^{*}$ & $0.25-$ & & & \\
\hline & & & & & & & & $<0.5^{*}$ & & & \\
\hline Redd & 33.1 & 15.9 & 15.0 & 13.5 & 9.1 & 6.1 & 3.3 & 1.8 & 1.3 & 0.4 & 0.4 \\
\hline $\mathrm{N}=30$ & \pm 7.5 & \pm 3.1 & \pm 2.4 & \pm 2.7 & \pm 1.9 & \pm 1.3 & \pm 0.8 & \pm 0.4 & \pm 0.3 & \pm 0.1 & \pm 0.1 \\
\hline Non-redd & 26.7 & 16.0 & 15.4 & 14.1 & 9.5 & 7.1 & 4.1 & 2.7 & 2.4 & 0.9 & 0.9 \\
\hline \multirow[t]{2}{*}{$\mathrm{N}=30$} & \pm 7.3 & \pm 3.3 & \pm 2.4 & \pm 2.7 & \pm 2.2 & \pm 1.4 & \pm 0.8 & \pm 0.7 & \pm 0.8 & \pm 0.3 & \pm 0.2 \\
\hline & \multicolumn{11}{|c|}{ Fall 1999} \\
\hline Redd & 22.6 & 20.0 & 17.6 & 14.3 & 10.3 & 6.0 & 3.8 & 2.5 & 1.7 & 0.6 & 0.7 \\
\hline$N=39$ & \pm 6.1 & \pm 3.6 & \pm 2.0 & \pm 2.0 & \pm 1.8 & \pm 1.3 & \pm 0.9 & \pm 0.8 & \pm 0.6 & \pm 0.2 & \pm 0.1 \\
\hline Non-redd & 21.0 & 18.1 & 17.3 & 14.2 & 10.1 & 6.3 & 4.5 & 3.3 & 2.8 & 1.1 & 1.3 \\
\hline $\mathrm{N}=39$ & \pm 5.6 & \pm 2.5 & \pm 2.4 & \pm 1.8 & \pm 1.8 & \pm 1.2 & \pm 0.9 & \pm 0.9 & \pm 0.9 & \pm 0.3 & \pm 0.2 \\
\hline
\end{tabular}


Table 2. Mean percent less than each sediment size class for redds and non-redds collected in both years.

(95\% CI below mean).

\begin{tabular}{|c|c|c|c|c|c|c|c|c|c|c|}
\hline \multirow[b]{3}{*}{ Sample } & \multicolumn{10}{|c|}{ Sieve mesh size $(\mathrm{mm})$} \\
\hline & \multirow{3}{*}{$<32$} & \multirow{3}{*}{$<16$} & \multirow{3}{*}{$<8$} & \multirow{3}{*}{$<4$} & \multicolumn{2}{|c|}{ Fall 1998} & \multirow{3}{*}{$<0.5$} & \multirow{3}{*}{$<0.25$} & \multirow{3}{*}{$<0.125$} & \multirow{3}{*}{$<0.06$} \\
\hline & & & & & $<2$ & $<1$ & & & & \\
\hline \multicolumn{3}{|l|}{ location } & & & & & & & & \\
\hline Redd & 66.9 & 51.0 & 35.9 & 22.5 & 13.4 & 7.2 & 3.9 & 2.1 & 0.8 & 0.4 \\
\hline $\mathrm{N}=30$ & \pm 7.4 & \pm 8.0 & \pm 6.4 & \pm 4.2 & \pm 2.5 & \pm 1.5 & \pm 0.9 & \pm 0.5 & \pm 0.2 & \pm 0.1 \\
\hline Non-redd & 73.3 & 57.2 & 41.8 & 27.7 & 18.2 & 11.1 & 7.0 & 4.3 & 1.8 & 0.9 \\
\hline $\mathrm{N}=30$ & \pm 7.3 & \pm 8.3 & \pm 6.9 & \pm 4.9 & \pm 3.4 & \pm 2.4 & \pm 1.8 & \pm 1.0 & \pm 0.4 & \pm 0.2 \\
\hline & \multicolumn{10}{|c|}{ Fall 1999} \\
\hline Redd & 77.4 & 57.4 & 39.8 & 25.5 & 15.2 & 9.2 & 5.4 & 2.9 & 1.3 & 0.7 \\
\hline $\mathrm{N}=39$ & \pm 6.2 & \pm 7.1 & \pm 6.3 & \pm 4.7 & \pm 3.2 & \pm 2.3 & \pm 1.6 & \pm 1.0 & \pm 0.3 & \pm 0.1 \\
\hline Non-redd & 79.0 & 60.9 & 43.6 & 29.4 & 19.2 & 12.9 & 8.4 & 5.1 & 2.3 & 1.3 \\
\hline $\mathrm{N}=39$ & \pm 5.6 & \pm 6.6 & \pm 6.0 & \pm 4.7 & \pm 3.5 & \pm 2.8 & \pm 2.2 & \pm 1.4 & \pm 0.5 & \pm 0.2 \\
\hline
\end{tabular}


Table 3. Average geometric mean diameter $\left(d_{g}\right)$ and fredle index $\left(f_{i}\right)$ values for redds and non-redds in both years (95\% CI next to mean).

\begin{tabular}{ccccc}
\hline & \multicolumn{2}{c}{ Fall 1998 $(\mathrm{n}=30)$} & \multicolumn{2}{c}{ Fall 1999 $(\mathrm{n}=39)$} \\
Sample location & $d_{g}$ & $f_{i}$ & $d_{g}$ & $f_{i}$ \\
& $(\mathrm{~mm})$ & $(\mathrm{mm})$ & \\
\hline Redd & $6.4 \pm 1.0$ & $2.9 \pm 0.6$ & $6.6 \pm 0.9$ & $3.1 \pm 0.6$ \\
Non-redd & $5.2 \pm 0.7$ & $2.1 \pm 0.5$ & $5.4 \pm 0.7$ & $2.2 \pm 0.4$ \\
\hline
\end{tabular}


Table 4. Statistical comparison of substrate for redds and non-redds between fall 1998 and 1999. Significant differences are denoted with an asterix $(*) .(+)=$ increase in percentage from 1998 to 1999. (-) = decrease in percentage from 1998 to 1999.

Sample location

\begin{tabular}{|c|c|c|}
\hline \multirow[b]{2}{*}{$\begin{array}{l}\text { Sieve mesh size } \\
\qquad(\mathrm{mm})\end{array}$} & \multicolumn{2}{|c|}{ Sample location } \\
\hline & Redd & Non-redd \\
\hline$>32$ & $*(-)$ & $(+)$ \\
\hline 16 to $<32$ & $(+)$ & $(+)$ \\
\hline 8 to $<16$ & $(+)$ & $(+)$ \\
\hline 4 to $<8$ & $(+)$ & $(+)$ \\
\hline 2 to $<4$ & $(+)$ & $(+)$ \\
\hline 1 to $<2$ & $(+)$ & $(-)$ \\
\hline 0.5 to $<1$ & $(+)$ & $(+)$ \\
\hline 0.25 to $<0.5$ & $(+)$ & $(+)$ \\
\hline 0.125 to $<0.25$ & $(+)$ & $(+)$ \\
\hline 0.063 to $<0.125$ & $(+)$ & $(+)$ \\
\hline$<0.063$ & $*(+)$ & $*(+)$ \\
\hline
\end{tabular}


Table 5. Brook trout density (fish/ha) in all study streams for all four survey periods (standard error in parentheses).

\begin{tabular}{|c|c|c|c|c|c|c|c|c|c|c|c|c|}
\hline \multirow[b]{2}{*}{ Stream name } & \multicolumn{3}{|c|}{ Fall 1998} & \multicolumn{3}{|c|}{ Summer 1999} & \multicolumn{3}{|c|}{ Fall 1999} & \multicolumn{3}{|c|}{ Summer 2000} \\
\hline & Adult & YOY & Total & Adult & YOY & Total & Adult & YOY & Total & Adult & YOY & Total \\
\hline Elleber Run & $\begin{array}{c}4789 \\
(1092)\end{array}$ & $\begin{array}{l}1575 \\
(701)\end{array}$ & $\begin{array}{l}6472 \\
(887)\end{array}$ & $\begin{array}{l}3528 \\
(566)\end{array}$ & $\begin{array}{c}3436 \\
(66)\end{array}$ & $\begin{array}{l}6964 \\
(565)\end{array}$ & $\begin{array}{l}2489 \\
(209)\end{array}$ & $\begin{array}{l}2774 \\
(145)\end{array}$ & $\begin{array}{l}5264 \\
(263)\end{array}$ & $\begin{array}{l}1269 \\
(65)\end{array}$ & $\begin{array}{c}824 \\
(193)\end{array}$ & $\begin{array}{l}2093 \\
(255)\end{array}$ \\
\hline Lick Run & $\begin{array}{l}2099 \\
(506)\end{array}$ & $\begin{array}{c}65 \\
(65)\end{array}$ & $\begin{array}{l}2164 \\
(561)\end{array}$ & $\begin{array}{c}664 \\
(287)\end{array}$ & $\begin{array}{c}689 \\
(549)\end{array}$ & $\begin{array}{l}1353 \\
(270)\end{array}$ & $\begin{array}{c}746 \\
(421)\end{array}$ & $\begin{array}{c}434 \\
(434)\end{array}$ & $\begin{array}{l}1180 \\
(204)\end{array}$ & $\begin{array}{c}295 \\
(132)\end{array}$ & 0 & $\begin{array}{c}295 \\
(132)\end{array}$ \\
\hline Little Low Place & $\begin{array}{c}7854 \\
(2407)\end{array}$ & $\begin{array}{l}2083 \\
(497)\end{array}$ & $\begin{array}{c}9937 \\
(2772)\end{array}$ & $\begin{array}{c}6877 \\
(1601)\end{array}$ & $\begin{array}{l}1399 \\
(163)\end{array}$ & $\begin{array}{c}8276 \\
(1629)\end{array}$ & $\begin{array}{c}3648 \\
(1009)\end{array}$ & $\begin{array}{l}763 \\
(87)\end{array}$ & $\begin{array}{l}4411 \\
(950)\end{array}$ & $\begin{array}{l}3024 \\
(675)\end{array}$ & $\begin{array}{c}619 \\
(169)\end{array}$ & $\begin{array}{l}3643 \\
(508)\end{array}$ \\
\hline Long Run & $\begin{array}{c}3084 \\
(1296)\end{array}$ & $\begin{array}{c}358 \\
(219)\end{array}$ & $\begin{array}{c}3442 \\
(1428)\end{array}$ & $\begin{array}{l}916 \\
(84)\end{array}$ & $\begin{array}{l}1486 \\
(457)\end{array}$ & $\begin{array}{l}2402 \\
(540)\end{array}$ & $\begin{array}{c}382 \\
(188)\end{array}$ & $\begin{array}{l}1306 \\
(110)\end{array}$ & $\begin{array}{l}1687 \\
(296)\end{array}$ & $\begin{array}{l}569 \\
(85)\end{array}$ & $\begin{array}{l}137 \\
(48)\end{array}$ & $\begin{array}{l}706 \\
(38)\end{array}$ \\
\hline Mullenax Run & $\begin{array}{c}465 \\
(144)\end{array}$ & $\begin{array}{l}330 \\
(77)\end{array}$ & $\begin{array}{c}794 \\
(221)\end{array}$ & $\begin{array}{l}161 \\
(10)\end{array}$ & $\begin{array}{l}1164 \\
(242)\end{array}$ & $\begin{array}{l}1324 \\
(233)\end{array}$ & $\begin{array}{c}47 \\
(28)\end{array}$ & $\begin{array}{c}592 \\
(213)\end{array}$ & $\begin{array}{c}639 \\
(240)\end{array}$ & $\begin{array}{c}77 \\
(25)\end{array}$ & $\begin{array}{l}67 \\
(9)\end{array}$ & $\begin{array}{l}143 \\
(33)\end{array}$ \\
\hline Poca Run & $\begin{array}{c}2822 \\
(1015)\end{array}$ & $\begin{array}{c}804 \\
(588)\end{array}$ & $\begin{array}{c}3627 \\
(1243)\end{array}$ & $\begin{array}{c}3026 \\
(1382)\end{array}$ & $\begin{array}{l}2978 \\
(821)\end{array}$ & $\begin{array}{l}6004 \\
(943)\end{array}$ & $\begin{array}{c}1485 \\
(1313)\end{array}$ & $\begin{array}{l}1708 \\
(255)\end{array}$ & $\begin{array}{c}3194 \\
(1073)\end{array}$ & $\begin{array}{l}1070 \\
(500)\end{array}$ & $\begin{array}{l}2113 \\
(920)\end{array}$ & $\begin{array}{c}3183 \\
(1200)\end{array}$ \\
\hline Sawmill Run & $\begin{array}{c}\text { no } \\
\text { data }^{1}\end{array}$ & $\begin{array}{c}\text { no } \\
\text { data }^{1}\end{array}$ & $\begin{array}{c}\text { no } \\
\text { data }^{1}\end{array}$ & $\begin{array}{c}4521 \\
(1029)\end{array}$ & $\begin{array}{c}865 \\
(457)\end{array}$ & $\begin{array}{c}5386 \\
(1483)\end{array}$ & $\begin{array}{c}3850 \\
(1088)\end{array}$ & $\begin{array}{c}620 \\
(235)\end{array}$ & $\begin{array}{c}4470 \\
(1323)\end{array}$ & $\begin{array}{l}1653 \\
(546)\end{array}$ & $\begin{array}{l}163 \\
(63)\end{array}$ & $\begin{array}{l}1815 \\
(548)\end{array}$ \\
\hline
\end{tabular}


Table 6. Brook trout biomass (gm/ha) in all study streams for all four survey periods (standard error in parentheses).

\begin{tabular}{|c|c|c|c|c|c|c|c|c|c|c|c|c|}
\hline \multirow[b]{2}{*}{ Stream name } & \multicolumn{2}{|c|}{ Fall 1998} & \multirow[b]{2}{*}{ Total } & \multicolumn{2}{|c|}{ Summer 1999} & \multirow[b]{2}{*}{ Total } & \multicolumn{2}{|c|}{ Fall 1999} & \multicolumn{4}{|c|}{ Summer 2000} \\
\hline & Adult & YOY & & Adult & YOY & & Adult & YOY & Total & Adult & YOY & Total \\
\hline Elleber Run & $\begin{array}{l}72381 \\
(9842)\end{array}$ & $\begin{array}{c}5954 \\
(2215)\end{array}$ & $\begin{array}{l}78336 \\
(9833)\end{array}$ & $\begin{array}{c}60909 \\
(11873)\end{array}$ & $\begin{array}{l}7030 \\
(422)\end{array}$ & $\begin{array}{c}67939 \\
(11536)\end{array}$ & $\begin{array}{l}47119 \\
(7228)\end{array}$ & $\begin{array}{l}7227 \\
(336)\end{array}$ & $\begin{array}{l}54346 \\
(7217)\end{array}$ & $\begin{array}{l}35902 \\
(3767)\end{array}$ & $\begin{array}{l}2386 \\
(437)\end{array}$ & $\begin{array}{l}38288 \\
(4098)\end{array}$ \\
\hline Lick Run & $\begin{array}{l}43822 \\
(5138)\end{array}$ & $\begin{array}{c}195 \\
(195)\end{array}$ & $\begin{array}{l}44017 \\
(5304)\end{array}$ & $\begin{array}{l}16521 \\
(7126)\end{array}$ & $\begin{array}{c}1773 \\
(1490)\end{array}$ & $\begin{array}{l}18294 \\
(5663)\end{array}$ & $\begin{array}{l}14028 \\
(8092)\end{array}$ & $\begin{array}{c}1499 \\
(1499)\end{array}$ & $\begin{array}{l}15527 \\
(6835)\end{array}$ & $\begin{array}{c}8082 \\
(3426)\end{array}$ & 0 & $\begin{array}{c}8082 \\
(3426)\end{array}$ \\
\hline $\begin{array}{l}\text { Little Low } \\
\text { Place }\end{array}$ & $\begin{array}{c}120671 \\
(35417)\end{array}$ & $\begin{array}{c}6498 \\
(1389)\end{array}$ & $\begin{array}{r}127168 \\
(35615)\end{array}$ & $\begin{array}{c}111589 \\
(18196)\end{array}$ & $\begin{array}{l}3360 \\
(234)\end{array}$ & $\begin{array}{r}114949 \\
(18215)\end{array}$ & $\begin{array}{c}59874 \\
(13008)\end{array}$ & $\begin{array}{l}2421 \\
(151)\end{array}$ & $\begin{array}{c}62295 \\
(12858)\end{array}$ & $\begin{array}{c}84671 \\
(14673)\end{array}$ & $\begin{array}{l}2117 \\
(682)\end{array}$ & $\begin{array}{c}86788 \\
(13994)\end{array}$ \\
\hline Long Run & $\begin{array}{c}74028 \\
(30044)\end{array}$ & $\begin{array}{c}1991 \\
(1053)\end{array}$ & $\begin{array}{c}76019 \\
(31097)\end{array}$ & $\begin{array}{l}29548 \\
(3264)\end{array}$ & $\begin{array}{l}2406 \\
(623)\end{array}$ & $\begin{array}{l}31954 \\
(3590)\end{array}$ & $\begin{array}{l}10157 \\
(3461)\end{array}$ & $\begin{array}{l}3689 \\
(219)\end{array}$ & $\begin{array}{l}13846 \\
(3475)\end{array}$ & $\begin{array}{c}13231 \\
(1764)\end{array}$ & $\begin{array}{c}529 \\
(219)\end{array}$ & $\begin{array}{r}13760 \\
(1703)\end{array}$ \\
\hline $\begin{array}{l}\text { Mullenax } \\
\text { Run }\end{array}$ & $\begin{array}{c}7845 \\
(2631)\end{array}$ & $\begin{array}{l}1503 \\
(266)\end{array}$ & $\begin{array}{c}9349 \\
(2893)\end{array}$ & $\begin{array}{l}2350 \\
(485)\end{array}$ & $\begin{array}{l}2663 \\
(662)\end{array}$ & $\begin{array}{l}5014 \\
(991)\end{array}$ & $\begin{array}{c}901 \\
(652)\end{array}$ & $\begin{array}{l}2173 \\
(597)\end{array}$ & $\begin{array}{c}3074 \\
(1249)\end{array}$ & $\begin{array}{c}892 \\
(707)\end{array}$ & $\begin{array}{l}239 \\
(51)\end{array}$ & $\begin{array}{l}1131 \\
(743)\end{array}$ \\
\hline Poca Run & $\begin{array}{c}59103 \\
(18265)\end{array}$ & $\begin{array}{c}2775 \\
(1885)\end{array}$ & $\begin{array}{c}61878 \\
(18676)\end{array}$ & $\begin{array}{c}78978 \\
(22101)\end{array}$ & $\begin{array}{c}6350 \\
(1424)\end{array}$ & $\begin{array}{c}85328 \\
(21448)\end{array}$ & $\begin{array}{c}18798 \\
(16630)\end{array}$ & $\begin{array}{l}3975 \\
(549)\end{array}$ & $\begin{array}{c}22773 \\
(16090)\end{array}$ & $\begin{array}{c}27223 \\
(13579)\end{array}$ & $\begin{array}{c}6594 \\
(2858)\end{array}$ & $\begin{array}{c}33818 \\
(14278)\end{array}$ \\
\hline Sawmill Run & $\begin{array}{c}\text { no } \\
\text { data }^{1}\end{array}$ & $\begin{array}{c}\text { no } \\
\text { data }^{1}\end{array}$ & $\begin{array}{c}\text { no } \\
\text { data } a^{1}\end{array}$ & $\begin{array}{c}88647 \\
(17168)\end{array}$ & $\begin{array}{c}2444 \\
(1054)\end{array}$ & $\begin{array}{c}91090 \\
(18160)\end{array}$ & $\begin{array}{c}71201 \\
(12538)\end{array}$ & $\begin{array}{l}2055 \\
(693)\end{array}$ & $\begin{array}{c}73256 \\
(13203)\end{array}$ & $\begin{array}{c}46412 \\
(15444)\end{array}$ & $\begin{array}{c}514 \\
(164)\end{array}$ & $\begin{array}{c}46925 \\
(15404)\end{array}$ \\
\hline
\end{tabular}

1 = Stream was not a study stream until after the fall 1998. 
Table 7. Significant relations for YOY density and biomass in summer 1999 and sediment sizes for redd and non-redd substrate collected in fall 1998. E = indicates the entire sample was used in calculation of percents. $\mathrm{T}=$ indicates the truncated samples were used in calculation of percents. Significant differences are denoted with an asterix $(*) .(+)=$ Positive relationship. $(-)=$ Negative relationship.

\begin{tabular}{|c|c|c|c|c|c|c|c|c|}
\hline \multirow{5}{*}{$\begin{array}{l}\text { Sieve mesh } \\
\text { size }(\mathrm{mm})\end{array}$} & \multicolumn{4}{|c|}{ YOY brook trout density summer } & \multicolumn{4}{|c|}{ YOY brook trout biomass summer } \\
\hline & \multicolumn{4}{|c|}{1999} & \multicolumn{4}{|c|}{1999} \\
\hline & \multicolumn{4}{|c|}{ (fish/ha) } & \multicolumn{4}{|c|}{ (gm/ha) } \\
\hline & \multicolumn{2}{|c|}{ Redds } & \multicolumn{2}{|c|}{ Non-redds } & \multicolumn{2}{|c|}{ Redds } & \multicolumn{2}{|c|}{ Non-redds } \\
\hline & $\mathrm{E}$ & $\mathrm{T}$ & E & $\mathrm{T}$ & $\mathrm{E}$ & $\mathrm{T}$ & $\mathrm{E}$ & $\mathrm{T}$ \\
\hline$<32$ & $(+)^{*}$ & & & & $(+) *$ & & & \\
\hline$<16$ & $(+) *$ & & & & $(+) *$ & & & \\
\hline \multicolumn{9}{|l|}{$<8$} \\
\hline \multicolumn{9}{|l|}{$<4$} \\
\hline \multicolumn{9}{|l|}{$<2$} \\
\hline \multicolumn{9}{|l|}{$<1$} \\
\hline$<0.5$ & $(+) *$ & & & & $(+) *$ & & & \\
\hline$<0.25$ & & & & & $(+) *$ & & & \\
\hline$<0.125$ & & & & & & $(-) *$ & & \\
\hline$<0.063$ & $(-) *$ & $(-) *$ & $(-) *$ & $(-) *$ & $(-) *$ & $(-) *$ & $(-) *$ & $(-) *$ \\
\hline
\end{tabular}


Table 8. Results of non-linear regression of redd and non-redd geometric mean diameter $\left(d_{g}\right)$ and fredle index $\left(f_{i}\right)$ values, and percent sediment composition for each sediment size class. All relationships were significant. $*=$ Indicates sediment size identified through MLR analysis that most influenced substrate permeability.

\begin{tabular}{|c|c|c|c|c|}
\hline \multirow[b]{2}{*}{$\begin{array}{l}\text { Sieve mesh size } \\
(\mathrm{mm})\end{array}$} & \multicolumn{2}{|c|}{ Redds } & \multicolumn{2}{|c|}{ Non-redds } \\
\hline & $\begin{array}{c}d_{g} \\
(\mathrm{~mm})\end{array}$ & $f_{i}$ & $\begin{array}{c}d_{g} \\
(\mathrm{~mm})\end{array}$ & $f_{i}$ \\
\hline 16 to $<32$ & $(+)$ & $(+)$ & $(+)$ & $(+)$ \\
\hline 8 to $<16$ & $(+)$ & $(+)$ & $(+)$ & $(+)$ \\
\hline 4 to $<8$ & $(-)$ & $(-)$ & $(+)$ & $(+)$ \\
\hline 2 to $<4$ & $(-)$ & $(-)$ & $(-)$ & $(-)$ \\
\hline 1 to $<2$ & $(-)$ & $(-)$ & $(-)$ & $(-)$ \\
\hline 0.5 to $<1$ & $*(-)$ & $*(-)$ & $*(-)$ & $(-)$ \\
\hline 0.25 to $<0.5$ & $(-)$ & $(-)$ & $(-)$ & $*(-)$ \\
\hline 0.125 to $<0.25$ & $(-)$ & $(-)$ & $(-)$ & $(-)$ \\
\hline 0.063 to $<0.125$ & $(-)$ & $(-)$ & $(-)$ & $(-)$ \\
\hline$<0.063$ & $(-)$ & $(-)$ & $(-)$ & $(-)$ \\
\hline
\end{tabular}


Table 9. Mean baseflow water chemistry values for November 1998 through September 2000 (range in parentheses).

\begin{tabular}{|c|c|c|c|c|}
\hline & & Specific & Dissolved & Dissolved oxygen \\
\hline & & conductance & oxygen & saturation \\
\hline Stream name & $\mathrm{pH}$ & (umhos) & $(\mathrm{mg} / \mathrm{L})$ & $(\%)$ \\
\hline Elleber Run & 7.1 & 20.0 & 8.6 & 87.7 \\
\hline & $(6.1-7.6)$ & $(10.7-36.0)$ & $(7.0-11.1)$ & (80.0-99.4) \\
\hline Lick Run & 7.0 & 23.1 & 8.2 & 82.3 \\
\hline & $(6.4-8.0)$ & $(13.2-42.8)$ & $(6.1-12.0)$ & $(68.7-100.0)$ \\
\hline Little Low Place & 7.2 & 36.9 & 8.7 & 87.7 \\
\hline & $(6.0-7.8)$ & $(20.2-57.9)$ & $(6.9-11.2)$ & $(79.3-100.0)$ \\
\hline Long Run & 7.2 & 23.7 & 8.4 & 84.1 \\
\hline & $(6.5-7.9)$ & $(12.8-41.3)$ & $(6.2-12.5)$ & $(64.3-100.0)$ \\
\hline Mullenax Run & 7.2 & 25.7 & 8.5 & 88.8 \\
\hline & $(6.0-7.7)$ & $(14.3-43.9)$ & $(6.4-11.3)$ & $(79.2-100.0)$ \\
\hline Poca Run & 7.0 & 19.5 & 8.7 & 86.1 \\
\hline & $(6.4-7.9)$ & $(12.1-33.5)$ & $(6.0-13.0)$ & $(68.3-100.0)$ \\
\hline Sawmill Run & 7.9 & 252.8 & 8.8 & 89.1 \\
\hline & $(6.9-8.5)$ & (194.8-286.8) & $(6.8-12.1)$ & $(80.6-100.0)$ \\
\hline
\end{tabular}


Table 10. Water chemistry analyses for the February 13 and May 24, 2000 storm events.

\begin{tabular}{|c|c|c|c|c|c|c|c|c|}
\hline $\begin{array}{l}\text { Stream } \\
\text { Name }\end{array}$ & $\begin{array}{c}\text { DOC } \\
(\mathrm{mg} / \mathrm{L})\end{array}$ & $\mathrm{pH}$ & $\begin{array}{c}\mathrm{ANC} \\
(\mu \mathrm{eq} / \mathrm{L})\end{array}$ & $\begin{array}{c}\text { Alkalinity } \\
(\mathrm{mg} / \mathrm{L})\end{array}$ & $\begin{array}{c}\mathrm{Mg} \\
(\mathrm{mg} / \mathrm{L})\end{array}$ & $\begin{array}{c}\mathrm{Ca} \\
(\mathrm{mg} / \mathrm{L})\end{array}$ & $\begin{array}{l}\text { Tot. Al } \\
(\mathrm{mg} / \mathrm{L})\end{array}$ & $\begin{array}{c}\text { Inorganic. Al } \\
(\mathrm{mg} / \mathrm{L})\end{array}$ \\
\hline \multicolumn{9}{|c|}{23 February 2000} \\
\hline Lick Run & 0.94 & 6.4 & 72.0 & 3.86 & 0.922 & 1.727 & 0.087 & 0.001 \\
\hline Long Run & 0.73 & 6.8 & 77.0 & 4.24 & 0.886 & 2.416 & 0.062 & 0.027 \\
\hline Poca Run & 0.46 & 6.7 & 47.0 & 2.79 & 0.875 & 1.814 & 0.042 & 0.042 \\
\hline Sawmill Run & 0.94 & 8.1 & 2883.0 & 162.43 & 3.176 & 51.51 & 0.137 & 0.066 \\
\hline \multicolumn{9}{|c|}{24 May 2000} \\
\hline Elleber Run & 0.726 & 6.8 & 71.0 & 3.66 & 0.687 & 1.752 & 0.017 & nd \\
\hline Lick Run & 1.671 & 6.8 & 111.0 & 5.57 & 0.894 & 2.006 & 0.022 & nd \\
\hline Little Low Place & 1.616 & 6.8 & 95.0 & 4.81 & 0.919 & 2.034 & 0.021 & nd \\
\hline Long Run & 1.283 & 6.8 & 88.0 & 4.40 & 0.825 & 2.024 & 0.022 & nd \\
\hline Mullenax & 2.488 & 6.8 & 94.0 & 4.90 & 0.480 & 2.494 & 0.030 & nd \\
\hline Poca Run & 1.109 & 6.4 & 59.0 & 3.11 & 0.821 & 1.713 & 0.017 & nd \\
\hline Sawmill Run & 1.817 & 8.0 & 2766.0 & 142.66 & 3.500 & 52.079 & 0.066 & 0.043 \\
\hline
\end{tabular}

nd = no detection at $0.001 \mathrm{mg} / \mathrm{L}$ limit 
Table 11. Mean daytime (9:00 - 21:00) water temperature $\left({ }^{\circ} \mathrm{C}\right)$ recorded hourly from June through August for all study streams in 1999 and 2000 (range in parentheses).

\begin{tabular}{|c|c|c|}
\hline Stream name & 1999 & 2000 \\
\hline \multirow[t]{2}{*}{ Elleber Run } & 15.2 & 13.7 \\
\hline & $(10.4-19.1)$ & $(9.8-15.9)$ \\
\hline \multirow[t]{2}{*}{ Lick Run } & 16.0 & 15.1 \\
\hline & $(10.3-19.9)$ & $(10.1-18.4)$ \\
\hline \multirow[t]{2}{*}{ Little Low Place } & 14.8 & 14.3 \\
\hline & $(10.9-17.9)$ & $(10.3-16.5)$ \\
\hline \multirow[t]{2}{*}{ Long Run } & 15.6 & 15.3 \\
\hline & $(10.6-20.0)$ & $(10.6-18.1)$ \\
\hline \multirow[t]{2}{*}{ Mullenax Run } & 17.4 & 16.6 \\
\hline & $(9.4-22.9)$ & $(9.9-21.2)$ \\
\hline \multirow[t]{2}{*}{ Poca Run } & 14.9 & 14.2 \\
\hline & $(10.1-18.4)$ & $(9.8-17.2)$ \\
\hline \multirow[t]{2}{*}{ Sawmill Run } & 16.4 & no data ${ }^{1}$ \\
\hline & $(10.4-20.2)$ & \\
\hline
\end{tabular}

$1=$ Temperature logger vandalized so no data was collected. 
Table 12. Habitat variables significantly influencing brook trout density and biomass in summer and fall 1999, and summer 2000. D $=$ Brook trout density. $B=$ Brook trout biomass. Significant differences are denoted with an asterix $(*) .(+)=$ Positive relationship.

\begin{tabular}{|c|c|c|c|c|c|c|c|c|c|c|c|c|c|c|c|c|c|c|}
\hline & \multicolumn{18}{|c|}{ Sample period } \\
\hline & \multicolumn{6}{|c|}{ Summer 1999} & \multicolumn{6}{|c|}{ Fall 1999} & \multicolumn{6}{|c|}{ Summer 2000} \\
\hline & \multicolumn{2}{|c|}{ Adults } & \multicolumn{2}{|c|}{ YOY } & \multicolumn{2}{|c|}{ Total } & \multicolumn{2}{|c|}{ Adults } & \multicolumn{2}{|c|}{ YOY } & \multicolumn{2}{|c|}{ Total } & \multicolumn{2}{|c|}{ Adults } & \multicolumn{2}{|c|}{ YOY } & \multicolumn{2}{|c|}{ Total } \\
\hline & $\mathrm{D}$ & $\mathrm{B}$ & $\mathrm{D}$ & B & $\mathrm{D}$ & B & $\mathrm{D}$ & B & $\mathrm{D}$ & B & $\mathrm{D}$ & B & $\mathrm{D}$ & B & $\mathrm{D}$ & B & $\mathrm{D}$ & B \\
\hline $\begin{array}{c}\text { Average water } \\
\text { depth }\end{array}$ & $\begin{array}{c}* \\
(+)\end{array}$ & $\begin{array}{c}* \\
(+)\end{array}$ & & & $\begin{array}{c}* \\
(+)\end{array}$ & $\begin{array}{c}* \\
(+)\end{array}$ & $\begin{array}{c}* \\
(+)\end{array}$ & $\begin{array}{c}* \\
(+)\end{array}$ & & & $\begin{array}{c}* \\
(+)\end{array}$ & $\begin{array}{c}* \\
(+)\end{array}$ & & & & & & \\
\hline $\begin{array}{l}\text { Average max. } \\
\text { pool depth }\end{array}$ & $\begin{array}{c}* \\
(+)\end{array}$ & $\begin{array}{c}* \\
(+)\end{array}$ & & & $\begin{array}{c}* \\
(+)\end{array}$ & $\begin{array}{c}* \\
(+)\end{array}$ & $\begin{array}{c}* \\
(+)\end{array}$ & $\begin{array}{c}* \\
(+)\end{array}$ & & & $\begin{array}{c}* \\
(+)\end{array}$ & $\begin{array}{c}* \\
(+)\end{array}$ & & & & & & \\
\hline $\begin{array}{l}\text { Stream } \\
\text { gradient }\end{array}$ & & & & & $\begin{array}{c}* \\
(+)\end{array}$ & $\begin{array}{c}* \\
(+)\end{array}$ & & & & & & & & & $\begin{array}{c}* \\
(+)\end{array}$ & $\begin{array}{c}* \\
(+)\end{array}$ & $\begin{array}{c}* \\
(+)\end{array}$ & $\begin{array}{c}* \\
(+)\end{array}$ \\
\hline $\begin{array}{l}\text { Spawning } \\
\text { substrate }\end{array}$ & $\begin{array}{c}* \\
(+)\end{array}$ & $\begin{array}{c}* \\
(+)\end{array}$ & & & $\begin{array}{c}* \\
(+)\end{array}$ & $\begin{array}{c}* \\
(+)\end{array}$ & $\begin{array}{c}* \\
(+)\end{array}$ & $\begin{array}{c}* \\
(+)\end{array}$ & & & $\begin{array}{c}* \\
(+)\end{array}$ & $\begin{array}{c}* \\
(+)\end{array}$ & & & & & & \\
\hline $\begin{array}{l}\text { Pool } \\
\text { area }\end{array}$ & & & & & & & $\begin{array}{c}* \\
(+)\end{array}$ & $\begin{array}{c}* \\
(+)\end{array}$ & & & & $\begin{array}{c}* \\
(+)\end{array}$ & & & & & & \\
\hline
\end{tabular}


Table 13. Stepwise MLR results for summer 1999 and fall 1999. nu = Variable not used in the MLR. Significant differences are denoted with an asterix (*).

\begin{tabular}{|c|c|c|c|c|c|}
\hline & \multicolumn{5}{|c|}{ Model Variables } \\
\hline & \multicolumn{5}{|c|}{ Average } \\
\hline & & & stream & & Percent \\
\hline & Dependent & Stream & water & Pool & sediment $<$ \\
\hline & variable & gradient & depth & area & $0.063 \mathrm{~mm}$ \\
\hline \multicolumn{6}{|c|}{ Summer 1999} \\
\hline \multirow[t]{3}{*}{ Density } & Adult & - & $*$ & - & $\overline{n u}$ \\
\hline & YOY & $\mathrm{nu}$ & - & nu & $*$ \\
\hline & Total & $*$ & $*$ & - & nu \\
\hline \multirow[t]{3}{*}{ Biomass } & Adult & $*$ & - & $*$ & $\mathrm{nu}$ \\
\hline & YOY & nu & - & nu & $*$ \\
\hline & Total & $*$ & & $*$ & nu \\
\hline \multicolumn{6}{|c|}{ Fall 1999} \\
\hline \multirow[t]{3}{*}{ Density } & Adult & - & $*$ & - & $\overline{\mathrm{nu}}$ \\
\hline & YOY & nu & - & nu & $*$ \\
\hline & Total & - & $*$ & - & $\mathrm{nu}$ \\
\hline \multirow[t]{3}{*}{ Biomass } & Adult & - & $*$ & - & $\overline{n u}$ \\
\hline & YOY & nu & - & $\mathrm{nu}$ & $*$ \\
\hline & Total & - & $*$ & - & $\mathrm{nu}$ \\
\hline
\end{tabular}




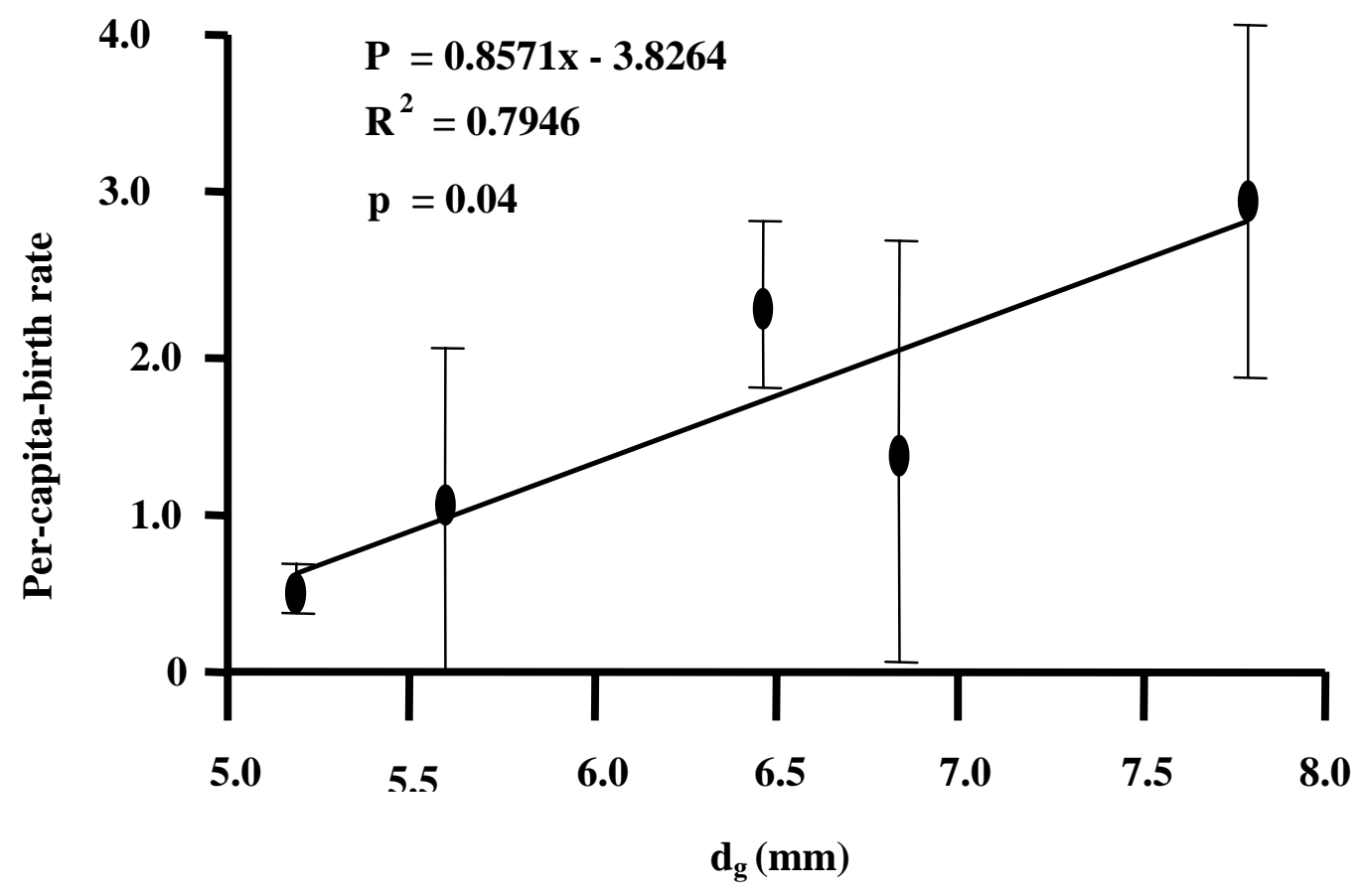

Figure 1. Relationship between $d_{g}$ of redd substrate in fall 1998 and brook trout per-capita-birth rate in summer 1999 (standard error bars). 

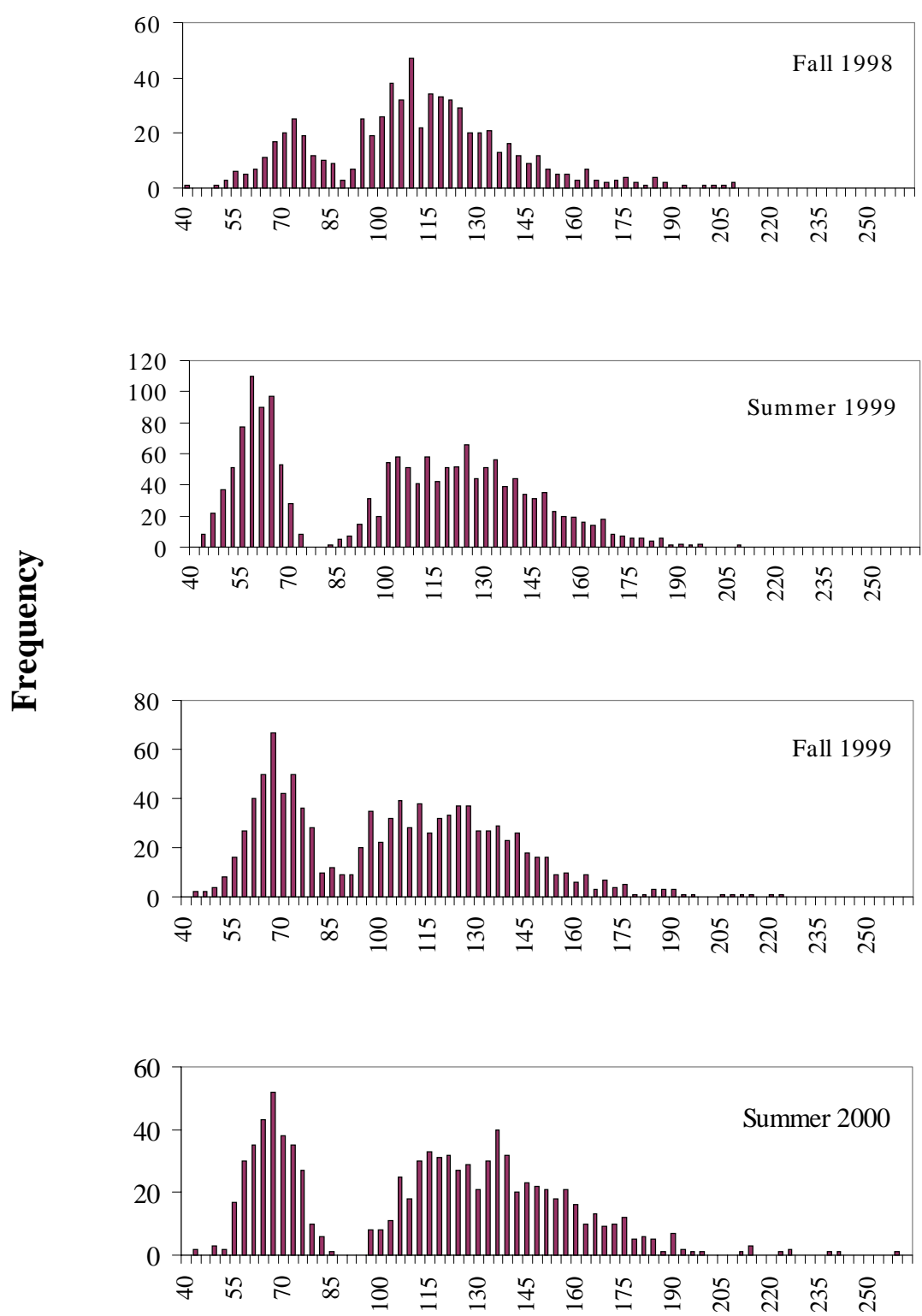

\section{Length (mm)}

Figure 2. Length-frequency histograms of brook trout length for all four sample periods. 


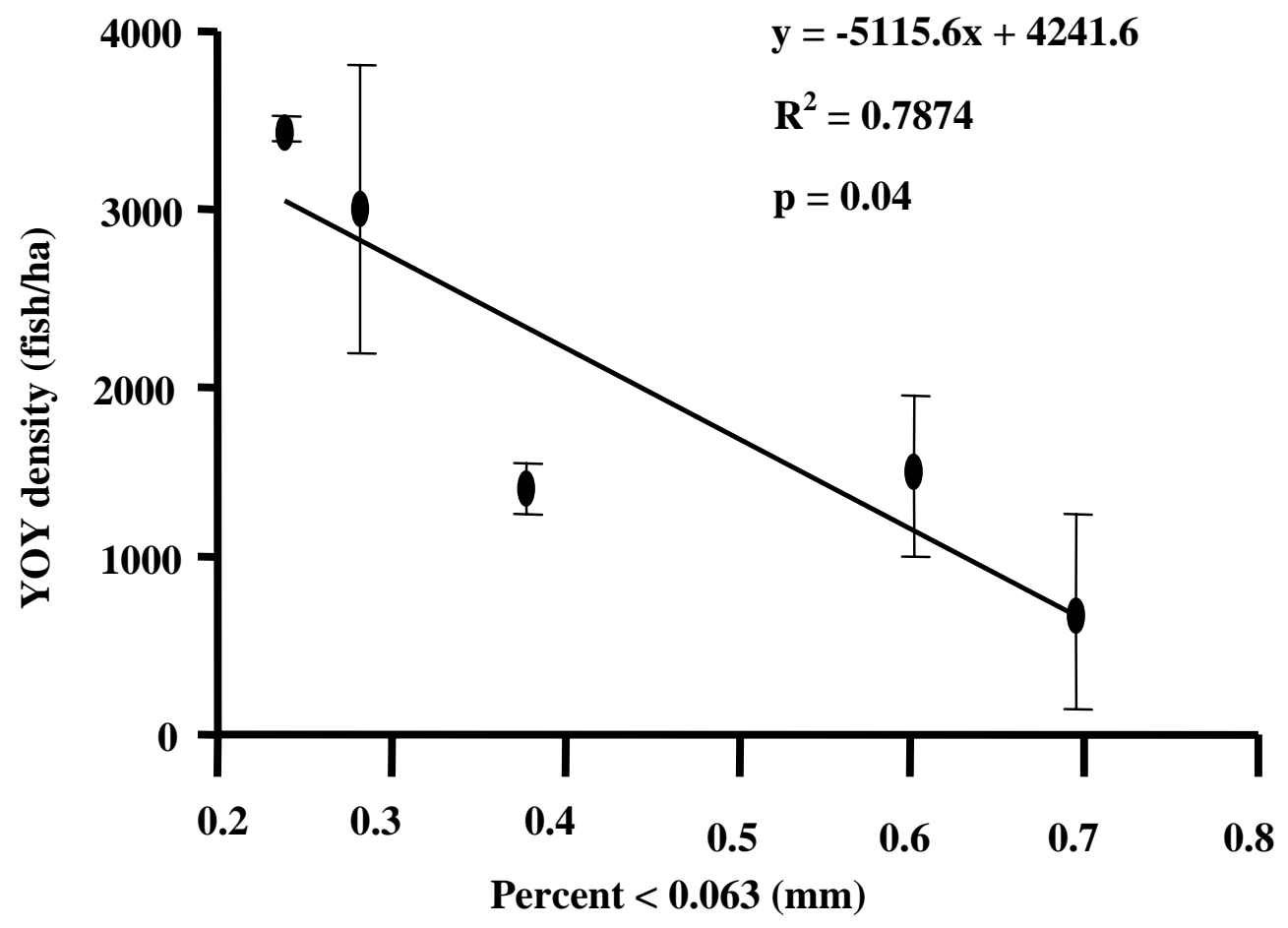

Figure 3. Relationship between fine sediment $<0.063 \mathrm{~mm}$ in fall 1998 redd substrate and YOY density in summer 1999 (standard error bars). 


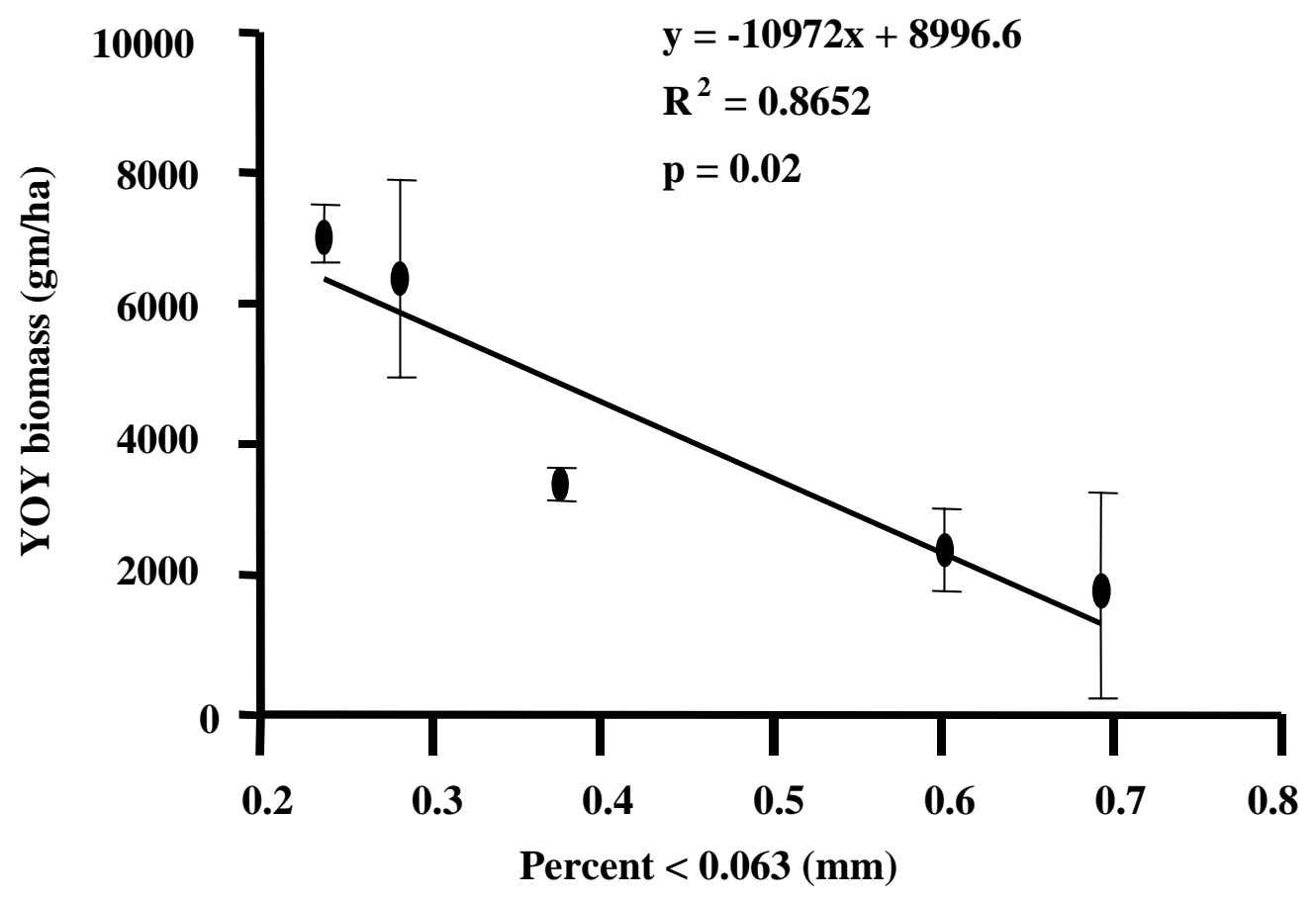

Figure 4. Relationship between fine sediment $<0.063 \mathrm{~mm}$ in fall 1998 redd substrate and YOY biomass in summer 1999 (standard error bars). 


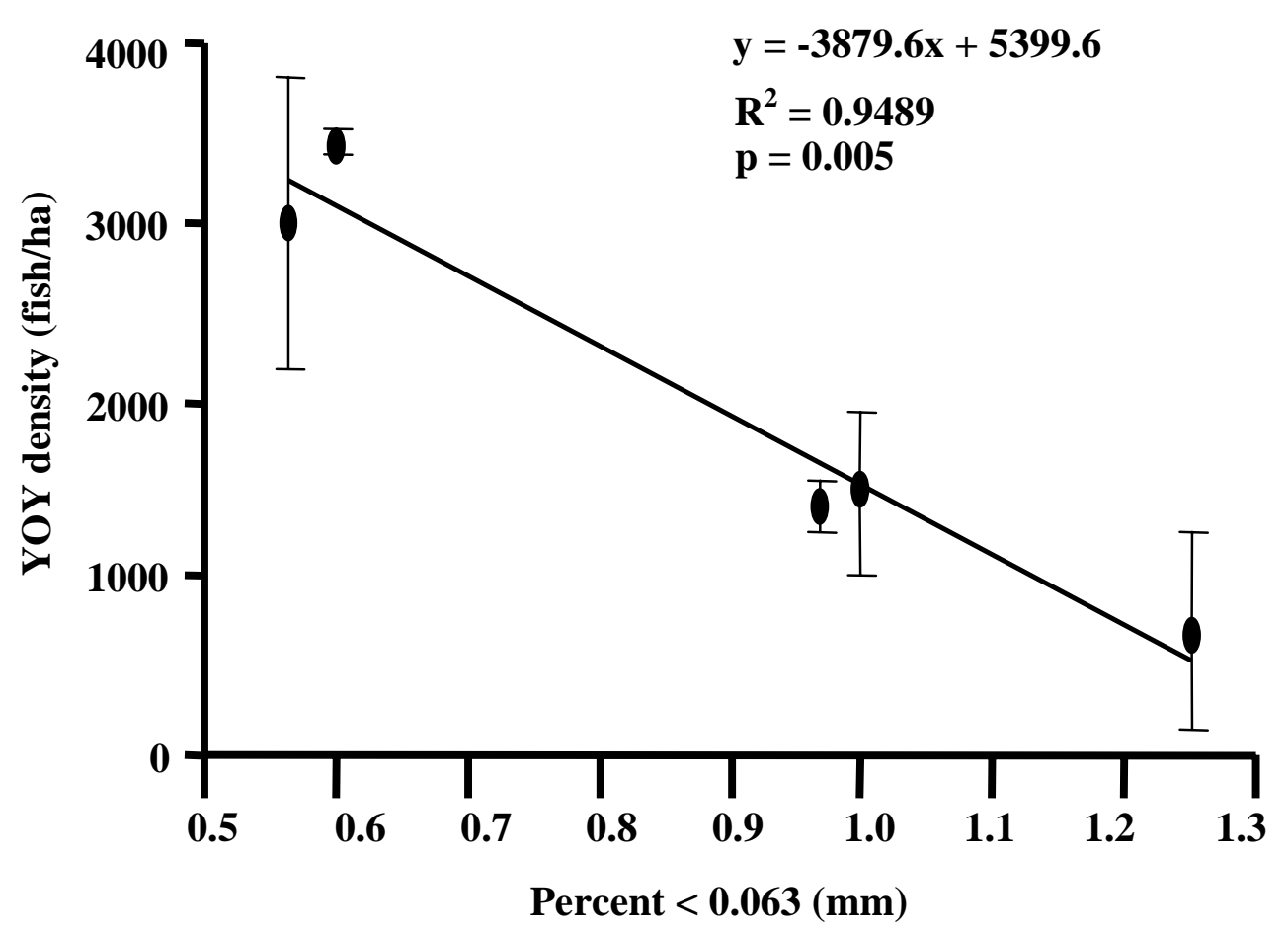

Figure 5. Relationship between fine sediment $<0.063 \mathrm{~mm}$ in fall 1998 non-redd substrate and YOY density in summer 1999 (standard error bars). 


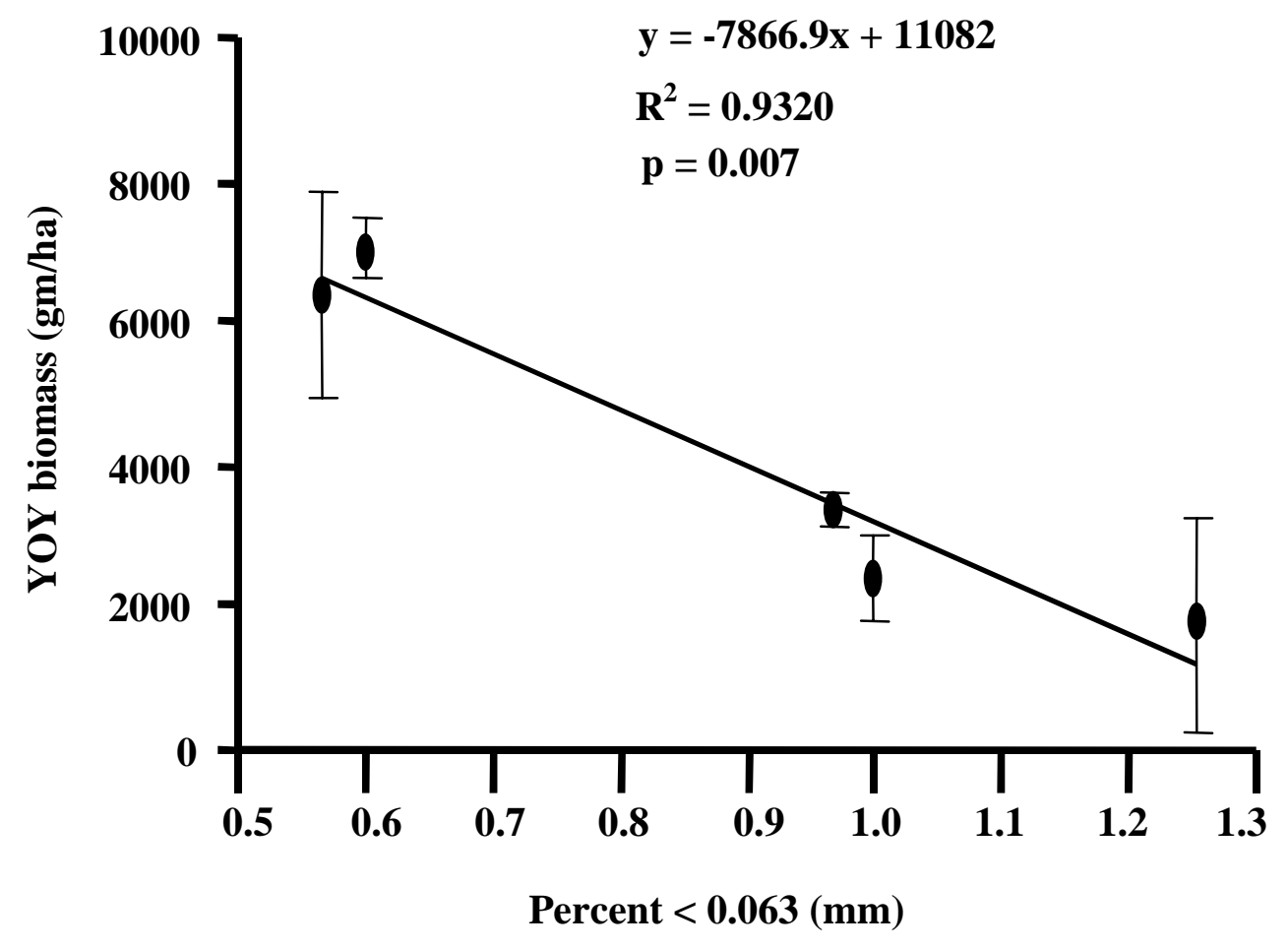

Figure 6. Relationship between fine sediment $<0.063 \mathrm{~mm}$ in fall 1998 non-redd substrate and YOY biomass in summer 1999 (standard error bars). 


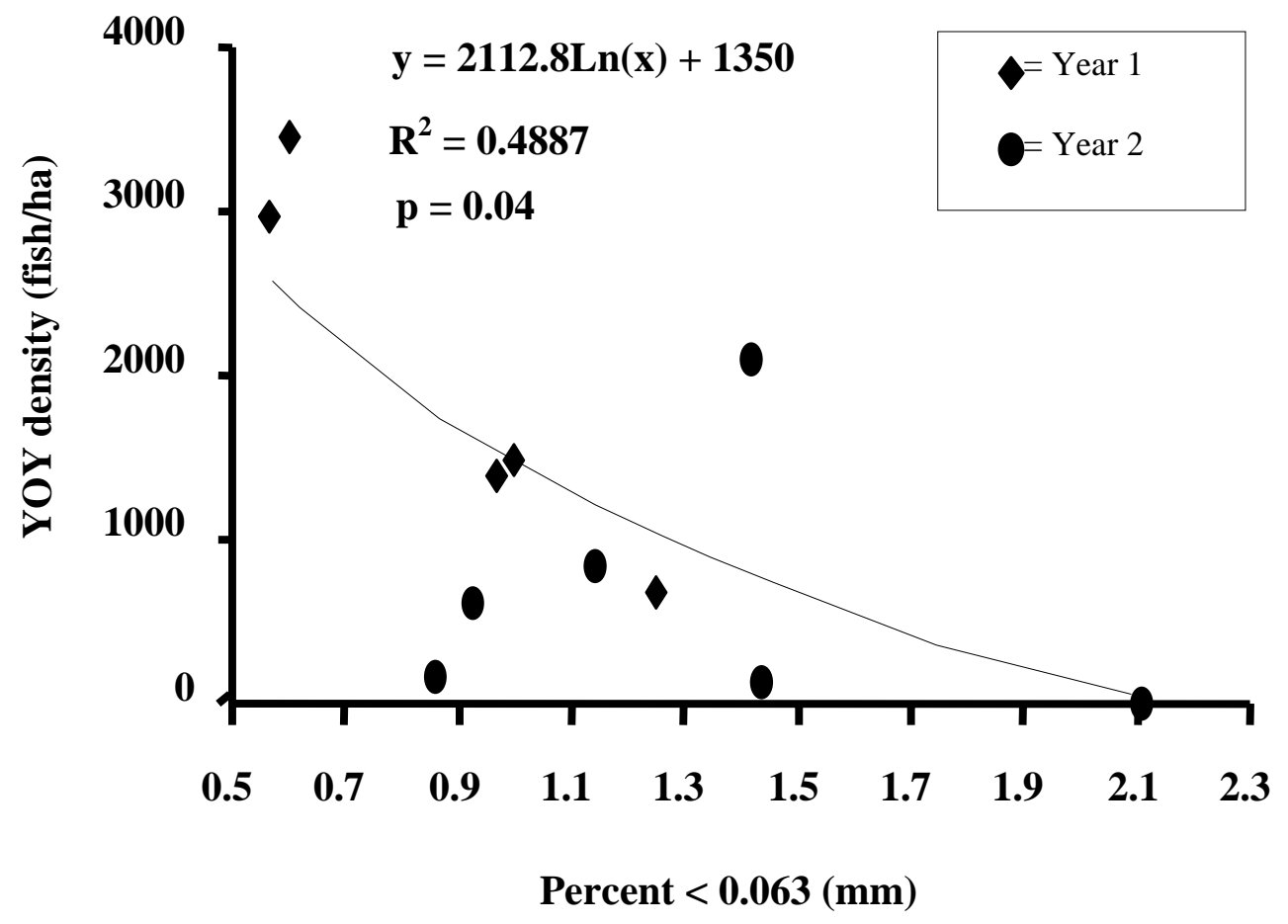

Figure 7. Relationship between fine sediment $<0.063 \mathrm{~mm}$ in non-redd substrate and YOY density for both year 1 (fall 1998) and year 2 (fall 1999). 


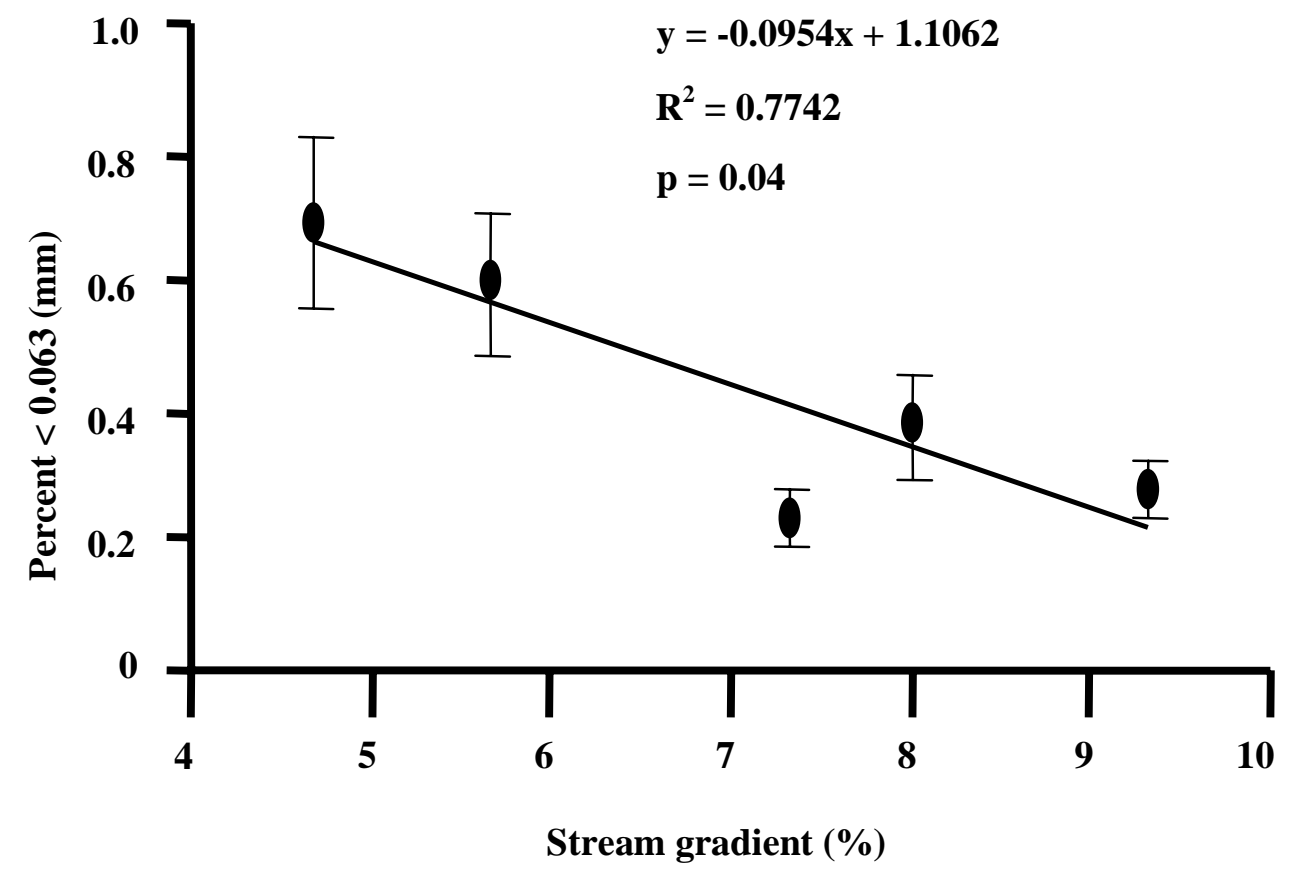

Figure 8. Relationship between fine sediment $<0.063 \mathrm{~mm}$ in brook trout redds and stream gradient in fall 1998 (standard error bars). 


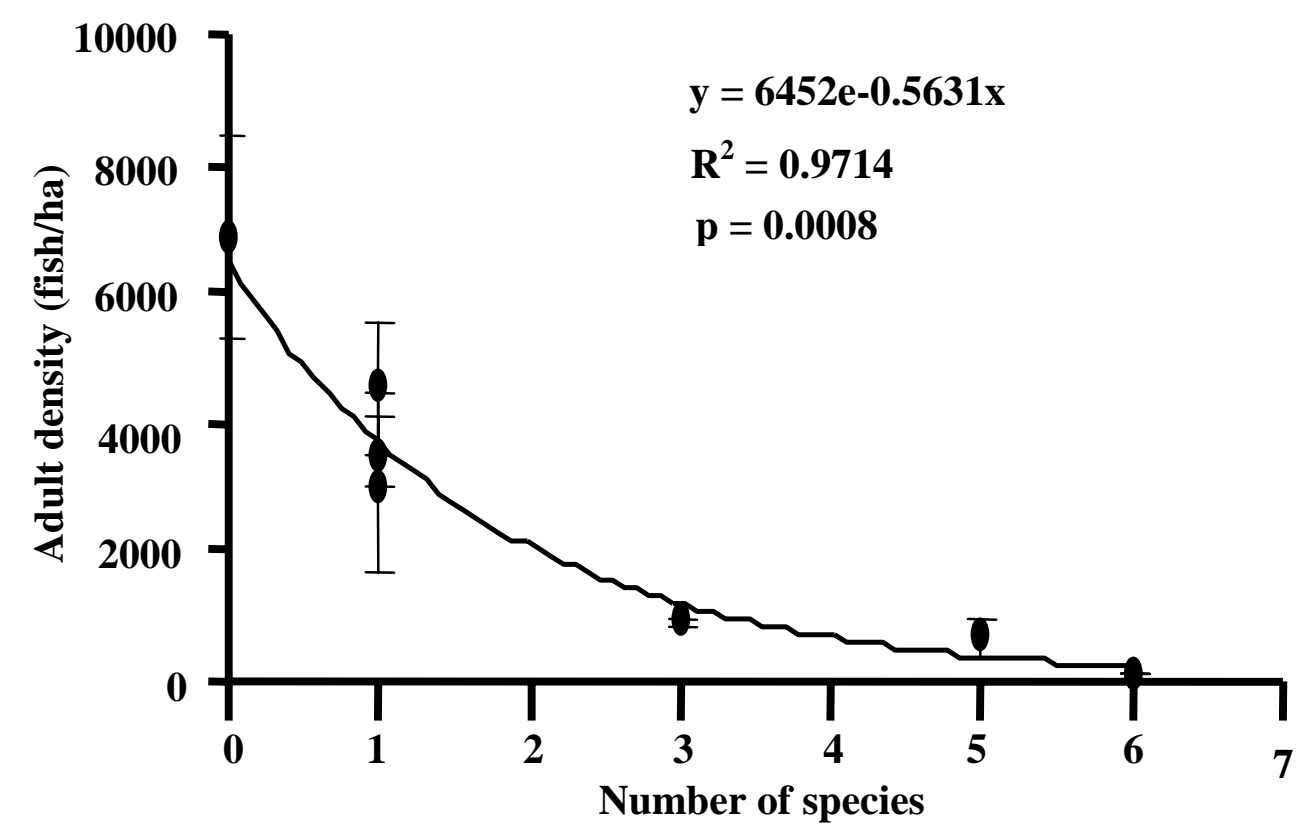

Figure 9. Relationship between non-trout species diversity and adult brook trout density in summer 1999 (standard error bars). 


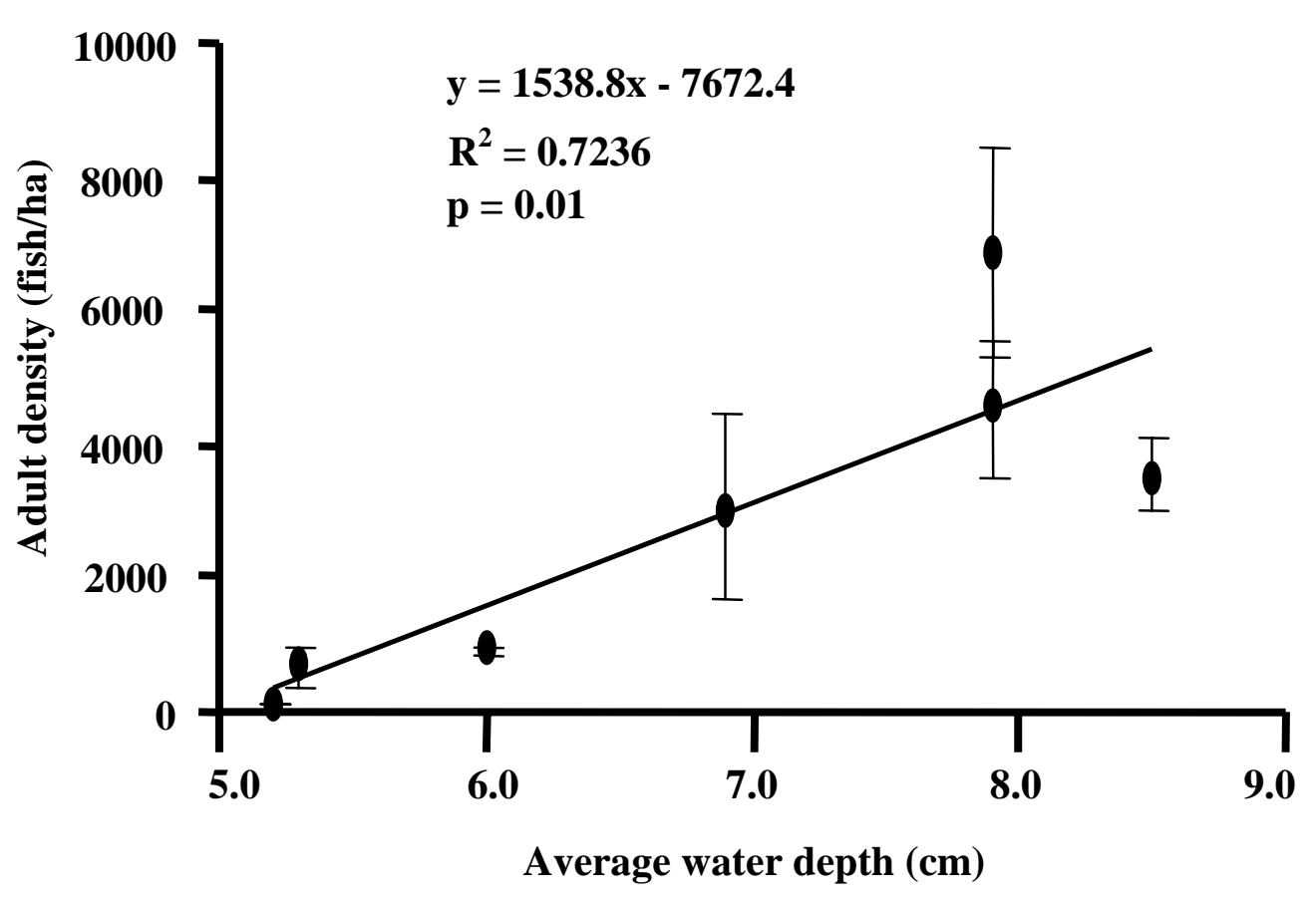

Figure 10. Relationship between average stream water depth and adult brook trout density in summer 1999 (standard error bars). 


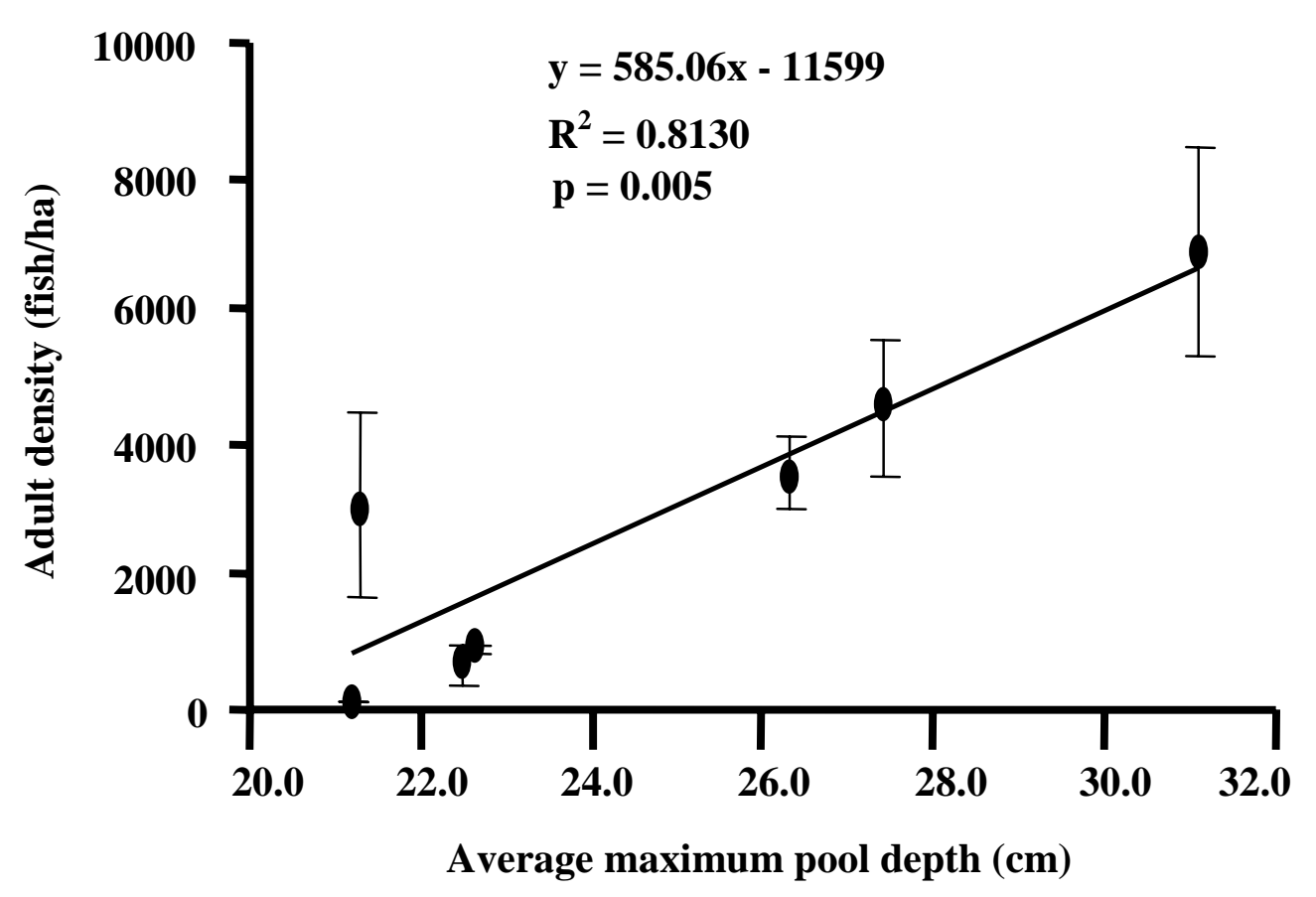

Figure 11. Relationship between average maximum pool depth and adult brook trout density in summer 1999 (standard error bars). 


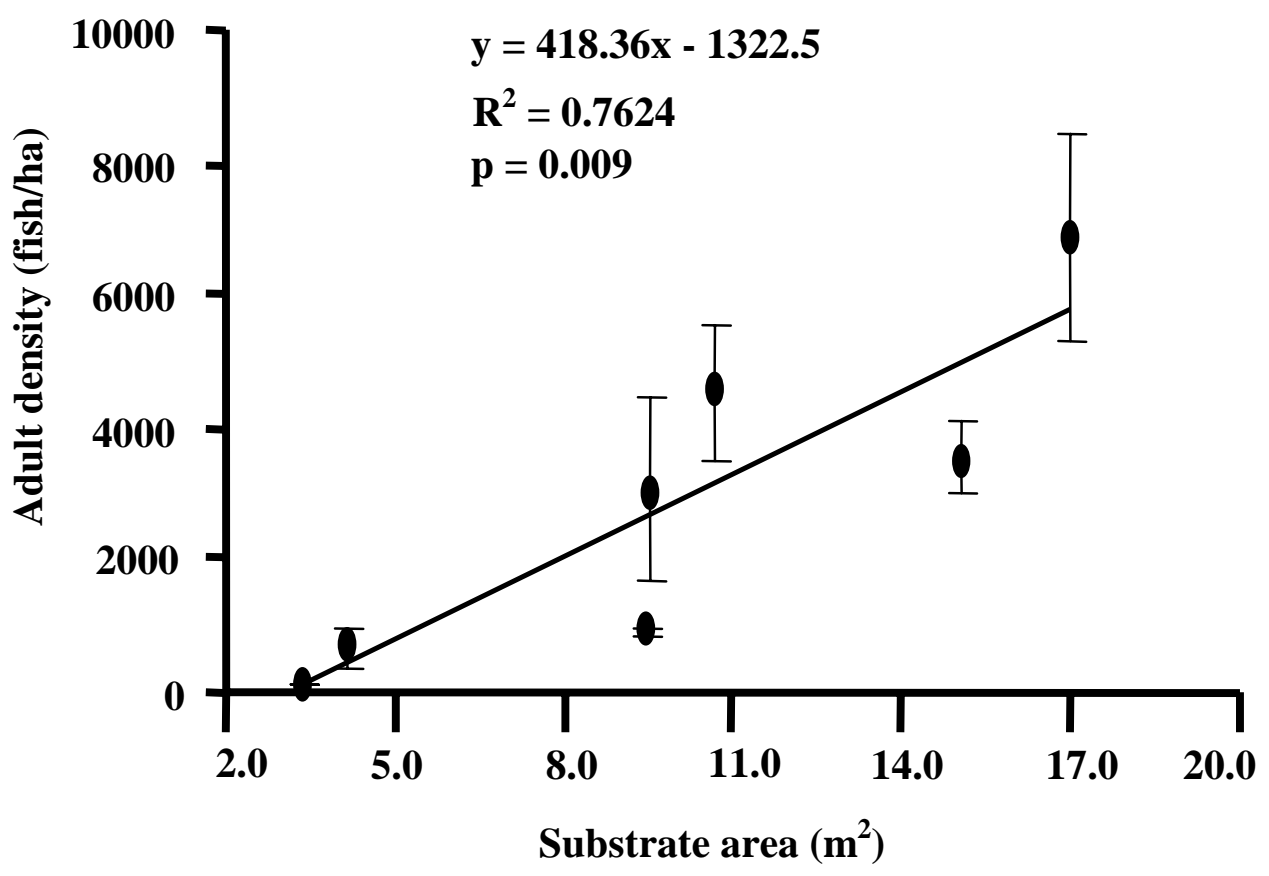

Figure 12.. Relationship between spawning substrate area and adult brook trout density in summer 1999 (standard error bars). 


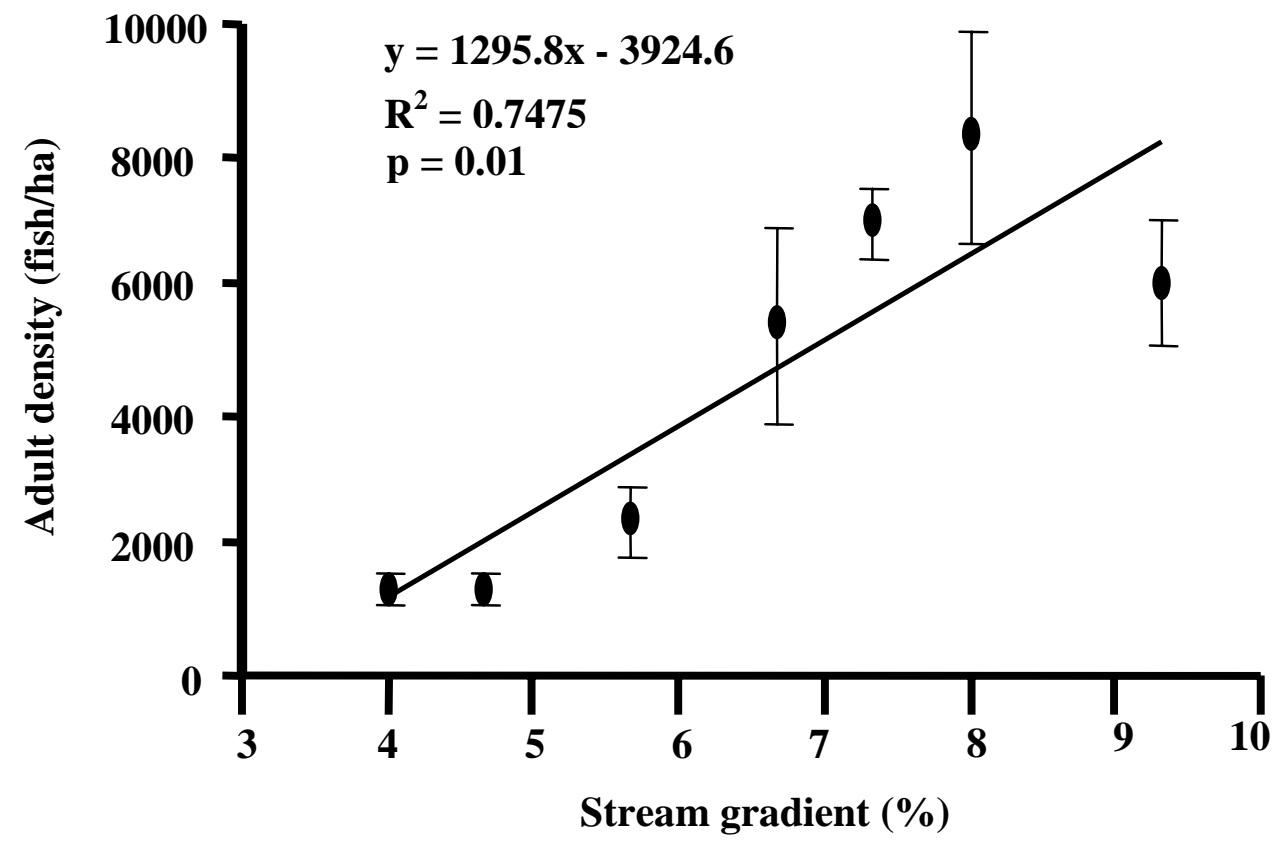

Figure 13. Relationship between stream gradient and adult brook trout density in summer 1999 (standard error bars). 


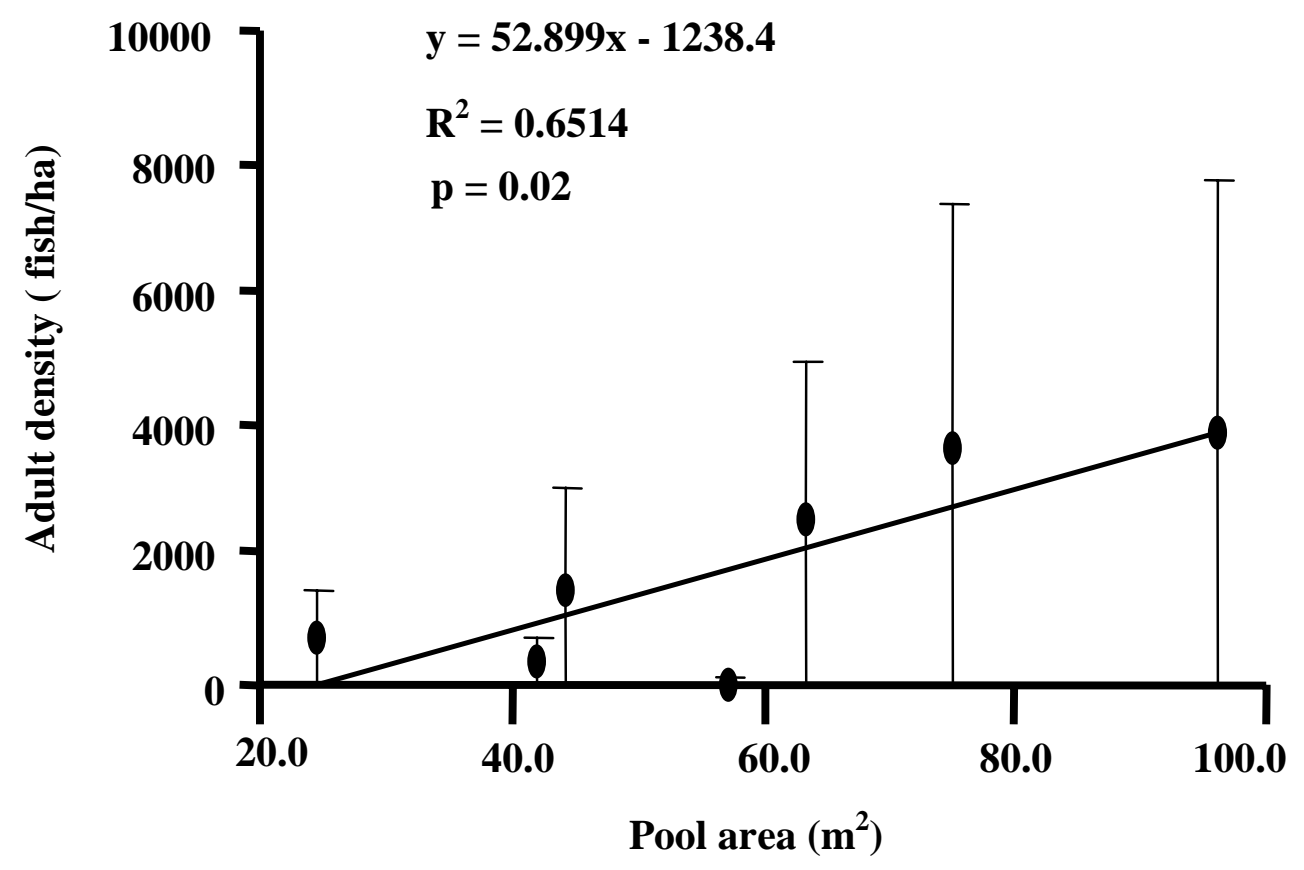

Figure 14. Relationship between pool area and adult brook trout density in fall 1999 (standard error bars). 


\title{
Chapter 3:
}

\section{Drought impact on stream morphology and brook trout populations in forested headwater streams}

\begin{abstract}
The effect of natural drought conditions in seven first and second order headwater streams was assessed. Changes in headwater stream morphology and the mechanisms causing observed changes in wild brook populations are discussed. Average stream discharge over all streams was $96 \%$ lower during drought conditions. As a result, habitat availability and quality over all study streams was reduced during the drought. Riffle area was reduced (54\%), twenty five times more relative to available pool area (2\%). As riffle habitat is the primary food producing area within a stream, food resources were presumably substantially reduced. Water temperature and dissolved oxygen were generally considered good for brook trout survival in all streams during the drought. However, brook trout populations were significantly reduced in the post drought period. Adult and YOY brook trout densities were $60 \%$ and $67 \%$ lower respectively, in the postdrought period. Body condition was also significantly lower during the drought relative to the post-drought period. Observed reductions in brook trout density and population condition during, and in the post drought period, are suggested to have been caused by spatially limited food resources within the systems, and not a function of degraded water quality.
\end{abstract}




\section{Introduction}

Drought conditions were experienced over much of the United States in 1999. The National Oceanic and Atmospheric Administration (NOAA) reported that the U.S. nationwide had experienced the $2^{\text {nd }}$ warmest and $22^{\text {nd }}$ driest year on record (1900-1999) (NOAA 1999). Drought intensity varied over the region, with West Virginia experiencing its $12^{\text {th }}$ driest year in the 100-year data set (NOAA 1999). Records for the Elkins, WV area (approximately 30 miles north of study area) showed 1999 to be the $5^{\text {th }}$ driest year on record (1899-1999). Annual mean discharge measured on the Greenbrier River at Durbin, WV (approximately 4 miles from study area) was 38\% lower than the 58-year average (Ward et al. 2000). The Palmer Drought Index (Palmer 1968) and Standardized Precipitation Index (McKee et al. 1993) (indices based upon soil moisture, precipitation and air temperature) classified the drought as "moderate" to "severe" over the region (NOAA 1999). By all accounts, the study area in 1999 experienced fairly harsh drought conditions that were reflected in extremely low flow conditions in all streams regionally.

Stream salmonid carrying capacity is suggested to be limited by habitat availability during summer low flow conditions (Elliot 1993, Lestelle et al. 1993). Wohl and Carline (1996) reported higher densities of brown trout (Salmo trutta) in a Pennsylvania stream maintaining higher annual water flows than another stream with lesser annual flows. As stream discharge decreases, so too does salmonid habitat availability (Kraft 1972, Wesche 1974, Hunt 1979, Randolph and White 1984). Researchers have demonstrated reductions in a number of spatial habitat measures as a consequence of diminished flow regimes. Total stream water volume (Elliot 2000) and 
water depth (Curtis 1959, Kraft 1972, Wesche 1974, Titus and Mosegaard 1992, Danehy et al. 1998) decrease in response to low water flows. Moreover, reductions in spatial habitat availability degrade instream cover quality for fishes (Kraft 1972, Wesche 1974, Hunt 1979, Randolph and White 1984). From these studies, it is apparent reductions in water flow profoundly impact stream conditions.

These sometimes drastic, drought-induced alterations of the habitat inherently impact the system's biota. Reduced habitat quality and availability has been linked to increased salmonid mortality, reduced growth, diminished migratory capacity and reduced reproductive potential (Wesche 1974, Brooker et al. 1977, Randolph and White 1984, Titus and Mosegaard 1992, Elliot 1993, Elliot et al. 1997, Bell et al. 2000, Elliot 2000).

Water quality has been demonstrated to decline as water flows decrease (Elliot 2000). Low flows may result in higher water temperatures (Hunt 1979, Wohl and Carline 1996) and lower dissolved oxygen concentrations (Brooker et al. 1977, Elliot 2000). Hunt (1979) reported that as summer maximum water temperatures increased, brook trout biomass was suppressed. The incipient lethal limit for brook trout is approached at a water temperature of $25.3{ }^{\circ} \mathrm{C}$ (Fry et al. 1946). However, in natural conditions the limit is closer to $24.0^{\circ} \mathrm{C}$ (MacCrimmon and Campbell 1969, Meisner 1990) with optimal water temperatures within the range of $14-16^{\circ} \mathrm{C}$ (Bjornn and Reiser 1991).

Low dissolved oxygen levels, which can occur during low water flow, are known to negatively impact salmonids (Brooker et al. 1977). Dissolved oxygen levels become harmful to brook trout at concentrations less than $5.0 \mathrm{mg} / \mathrm{L}$ (Spoor 1990). During periods of poor water quality and degraded habitat conditions, salmonids seek refuge in areas 
where conditions are suitable to survival. Elliot (2000) demonstrated deeper pool habitats maintained lower water temperatures and higher dissolved oxygen levels during drought periods than did shallower pools. These findings emphasize the importance of deep-water habitats during low stream flow episodes. Stream salmonids have been shown to seek pool areas during reduced flow conditions (Randolph and White 1984, Huntingford et al. 1999, Elliot and Hurley 1998 in Elliot 2000, Binns 1994). Kraft (1972) suggested the movement of brook trout into pools was in response to degrading habitat conditions. If such refuge habitat is unavailable, fish survival is potentially lowered during drought episodes.

Bottom fauna is the primary source of food for stream dwelling fishes (Curtis 1959, Chapman 1966, Allen 1969). Low flows diminish total food production area within a stream (Wesche 1974, Danehy et al. 1998). Curtis (1959), Kraft (1972) and Wesche (1974) demonstrated stream water velocity is largely a function of stream discharge. Slower water velocity decreases food delivery rates (Hunt 1979). Hawkins et al. (1983) suggested invertebrates in pools drift less, and are therefore less susceptible to predation. These studies suggest trout restricted to pool habitats during drought conditions may potentially have fewer available prey items, creating conditions conducive for poor growth and survival.

In addition to reducing prey delivery rates, decreased water flows increase fine sediment depositional rates in the streambed (Kraft 1972, Wright 1992). This has been suggested to be a function of reduced water velocity (Reiser and Wesche 1977). Fine sediment increases have negative consequences for both spawning gravel quality and salmonid food production. The impacts of fine sediment on salmonid embryos are well 
established (Iwamoto et al. 1978, Everest et al. 1987, Chapman 1988). Therefore, drought induced augmentation of fine sediment within the spawning bed may further compound the negative effect drought conditions have upon salmonid population dynamics. Moreover, increasing fine sediment decreases invertebrate densities (Hawkins et al. 1983, Hartman et al. 1996). As a consequence, potential food availability is further decreased during drought episodes.

Headwater systems have naturally high flow variability (Lanka et al. 1987), thus drought conditions may be expected to more profoundly influence morphological characteristics. Brook trout populations inhabiting such harsh environments may be limited through reduced carrying capacity. This research documents changes in stream morphology attributed to drought induced low flows. The resultant population effects on resident brook trout were quantified, and the casual mechanisms potentially at the root of the observed population changes are discussed.

\section{Materials and Methods}

Study Area. - The study area is within the east central portion of the Monongahela National Forest, West Virginia. The National Forest is located in the central Appalachian region of the U.S. Study streams are first and second order (Strahler 1957) headwater streams located in the East fork of the Greenbrier River, (GR) and the North Fork of the South Branch of the Potomac River drainage's (PR). The two drainage basins lie on either side of the eastern continental divide. The underlying sedimentary geology consists predominantly of Chemung and Hampshire shale. All streams are located in forested watersheds. Stream elevations range from 900-1150 m above sea level. Annual 
precipitation at Elkins, WV (approximately 30 miles north of the study area) is $112 \mathrm{~cm}$ (NOAA/NCDC 2000)

Streams in relative close proximity to one another (two adjacent watersheds) in geologic regions conducive to good year-round water quality were selected. This practice minimizes variation in salmonid densities due to geographic differences (Lanka et al. 1987). The seven streams studied were located in Pocahontas and Pendleton Counties, WV (drainage locations in parentheses). They include Elleber Run (GR), Lick Run (GR), Long Run (GR), Mullenax Run (GR), Poca Run (GR), Little Low Place (PR) and Sawmill Run (PR). Study streams are not stocked and all support wild brook trout populations. Fishing pressure has not been quantified in the area, but seems to increase with stream size, reputation of the fishery (J. Hakala, personal observation) and accessibility (McCullough 1997). Fishing pressure appeared light to non-existent in some streams, with greatest use of others occurring in late winter and early spring. All streams except Little Low Place are un-manipulated watercourses. At Little Low Place there are 19 habitat improvement structures (k-dams, v-dams) constructed in the 1960's and 1990's. These structures have generally created large deep pools on their lee. 
Methods. - Three $50 \mathrm{~m}$ sample reaches were permanently established at the lower, middle and upper portions of each study stream. Sample reach size was expanded to $100 \mathrm{~m}$ after the first of four sample periods (Armour et al. 1983) to better account for naturally high variations in stream fish densities (Wydoski and Cooper 1965, Platts and Nelson 1988). Total sample reach length averaged $18 \%$ (range 9-29\%) of the total study stream length.

A quantitative assessment of physical instream habitat was conducted in each sample reach within all seven study streams. Habitat assessments were conducted near baseflow conditions over a one-week period in late June of 1999 and 2000. U.S. Geological Survey (USGS) stage height data for the Greenbrier River at Durbin, WV (approximately 4 miles from study area) showed stage height during the June 1999 and 2000 habitat surveys varied less than $0.01 \mathrm{~m}$ over both sample periods ( S. Ward USGS, personal communication, preliminary data 2000). Habitat data were collected using a habitat-based sample design (Dolloff et al. 1997). Measurements were made of unit type, length, wetted width, water depth, maximum pool depth, pool cover quality and area of suitable spawning substrate.

Three habitat unit types (pool, riffle or glide) were classified based on general descriptive guidelines (Bisson et al. 1981). Habitat unit dimensions were measured using standard methodologies (Dolloff et al. 1997, Overton et al. 1997). Maximum water depth within pools was measured at the estimated deepest location. In addition, pool habitats were rated subjectively for their potential to provide cover for fish using rating criteria modified from Platts et al. (1983). All suitable spawning substrate was quantified as an area (Bozek and Rahel 1991b, Magee et al. 1996). Substrate ranging from 4 to $30 \mathrm{~mm}$, in 
at least $7 \mathrm{~cm}$ of low velocity water (generally tails of pools) was considered suitable spawning substrate (J. Hakala, personal observation). To assess the effect of drought conditions on stream morphology, statistical comparisons were made between summer 1999 (drought year) and the summer of 2000 (non-drought year). The habitat data used were not normally distributed so a non-parametric randomized block ANOVA (Friedmans test) was used to test the hypothesis of "no difference" between years. Individual streams were used as the blocking unit.

Post-assessment of sample reaches was made to determine if the selected sample reaches were statistically representative of the entire study stream. A modified basinwide habitat assessment technique (BVET) (Hankin and Reeves 1988) was used to collect habitat data over the entire study stream. Measures requiring observational interpretation were made by a single person to minimize observer bias (Roper and Scarnecchia 1995). Habitat unit type, length, wetted stream width, canopy cover, maximum pool depth, and pool cover rating were measured over the entire stream. Comparison was made for average stream wetted width, canopy cover, average maximum pool depth, pool cover rating, and pool and riffle area between the sample reaches and the entire stream. Habitat data were not normally distributed (Shapiro-Wilks normality test, SAS Institute 1999) (Herger et al. 1996). A Non-parametric t-test (Wilcoxon signed ranks test) was employed to statistically evaluate if the representative sample reaches were morphologically similar to the rest of the stream. A significance level of 0.05 was used for this and all subsequent statistical analyses. A t-test could not be used to assess pool and riffle area in the representative reaches. Instead, means determined for the entire stream were examined to see if they fell within the 95\% confidence interval (CI) about the sample reach mean. 
Stream discharge was measured using USGS techniques (USGS 1977).

Discharge data were collected once a year during near summer baseflow conditions. Discharge was calculated three times at the same location over a 15 min. period. All three measures were averaged to come up with a measure of total stream discharge. Average discharge over all streams was compared between the two years using a nonparametric t-test (Wilcoxon signed ranks test).

Water temperature data were collected continuously every hour from April 17, 1999 through September 2, 2000. Temperature data were recorded to the nearest $0.01{ }^{\circ} \mathrm{C}$ using Onset Corporation $\mathrm{HOBO}$ temperature loggers. Loggers were permanently affixed to the stream bottom using a PVC housing, chain and rebar to anchor the unit in place.

Dissolved oxygen (DO) and percent DO saturation were measured at least once a month from July through September during the 1999 drought. Measures were recorded at a single pool within each sample reach. Data were collected during the day when water temperatures were at their expected peak.

Daily precipitation data were collected from National Oceanic and Atmospheric Administration (NOAA) weather observatories located in Bartow, WV and Elkins, WV. Total precipitation between January 1 and August 31 was recorded for each year (19982000). Precipitation data were used to establish that drought conditions existed in 1999 (Bell et al. 2000). To assess the relative magnitude of the drought, precipitation data at the Bartow station was compared to 30 -year average precipitation data collected at the Elkins station (no such long-term data available at Bartow station).

Substrate samples were collected from spawning areas so inferences about substrate compositional changes could be related back to impacts on brook trout 
reproductive potential. Samples were collected in fall 1998 and fall 1999 to assess compositional changes in substrate during the drought. Samples were collected from known brook trout spawning areas (presence of redds) using a modification of the shovel technique (Grost et al. 1991). Substrate samples were taken to a depth of $8.0 \mathrm{~cm}$ which is the average depth egg pockets have been found for brook trout of similar size $(<250 \mathrm{~mm})$ as those found in these study streams (Young et al. 1989).

An average of 6 substrate samples (range 5-8) were collected annually from each study stream. No spawning substrate samples were collected from Mullenax Run in either year due to an inability to locate actively used spawning areas due to naturally low brook trout densities. This stream was excluded from further substrate analyses in both years. Sawmill Run was not used as a study stream until after fall 1998, thus substrate samples were not collected in that year. Substrate samples were collected and processed as described in the appendix of this document. Sediment sizes analyzed were > 32.0, $16.0,8.0,4.0,2.0,1.0,0.5,0.25,0.125$ and $<0.063 \mathrm{~mm}$

The geometric mean diameter $\left(d_{g}\right)$ and sorting coefficient $\left(S_{o}\right)$ (Krumbein and Pettijohn 1938) were calculated for each substrate sample using the equations of Lotspeich and Everest (1981). These two values were used to calculate the fredle index (fi) $\left(f_{i}=d_{g} / S_{o}\right)$ for each substrate sample (Lotspeich and Everest 1981). The $f_{i}$ is a measure of the substrate permeability and interstitial pore size, both of which evaluate the egg rearing potential of the substrate. (Chapman and McCleod 1987).

Population surveys were conducted in October 1998, July 1999, October 1999 and July 2000 in all sample reaches. Fish were collected using a Coffelt Model 12 backpack electrofisher. The direct pulsed DC electrofishing unit was set at a frequency 
of 60 hertz and a voltage range of 250-400 V depending on water conductivity. All fish were removed using a standard three-pass removal technique (as recommended by Riley and Fausch 1992). Occasionally a fourth pass was conducted if there was unsatisfactory depletion between the second and third pass. All brook trout captured were measured to the nearest $1.0 \mathrm{~mm}$ (total length $=\mathrm{TL}$ ) and weighed to the nearest $1.0 \mathrm{gm}$. Brook trout condition (Fulton-type) was calculated using the formula $\mathrm{K}=\mathrm{W} / \mathrm{L}^{3}$ (where $\mathrm{K}=$ condition; $\mathrm{L}=$ total fish length; $\mathrm{W}=$ fish weight) (Anderson and Gutreuter 1983). Determination of age 0 (YOY) and age 1+ (adult) fish was done through analysis of length-frequency histograms.

The program CAPTURE (White et al. 1982) was used to calculate separate maximum-likelihood population estimates and 95\% CI for YOY and adult brook trout. If less than 30 fish (YOY or adult) were captured in a given section then the actual number captured was used as the estimate. This is based on the findings of Riley and Fausch (1992) that the maximum-likelihood removal estimate "performs poorly" at sample sizes less than 30 individuals. The CAPTURE program runs a chi-square analysis to determine if the model assumption of equal catch probability between passes was satisfied. If the assumption was not satisfied for a particular population estimate, then the raw total catch was bootstrapped using the average catch efficiency for those estimates satisfying the model's assumption. Failure to meet the model's assumption occurred infrequently. Catch efficiency was calculated as the quotient of the actual number of fish captured and the derived population estimate for a sample reach (Lohr and West 1992).

Brook trout length, weight, and condition were analyzed separately for adults and YOY. Comparisons were made between drought (summer 1999 and fall 1999) and non- 
drought years (fall 1998 and summer 2000). Only comparison of adult condition were made between fall 1999 and summer 2000 because YOY from 1999 were recruited (adults) in spring 2000 making comparison of YOY between the sample intervals invalid. A Non-parametric randomized block (streams) ANOVA (Friedmans test) was used to test for differences in length, weight and condition between the sample periods.

\section{Results}

Comparison of average stream wetted width, maximum pool depth, pool cover rating, and pool and riffle area between sample reaches (measured in summer 1999) and the entire study stream (basinwide assessment, summer 1999) showed only one significant difference. Average stream wetted width in the sample reaches of Mullenax Run was significantly $(\mathrm{p}=0.0002)$ less than average wetted width over the rest of the study stream. Despite this difference in a single stream, the analysis provides evidence to suggest that the sample reaches selected in each study stream were very similar morphologically to the rest of the stream.

Water Quality. - Precipitation data showed 1999 was a drought year and both 1998 and 2000 were typical years for precipitation (Table 14). Precipitation for the study area was $20.6 \mathrm{~cm}$ below $(-26 \%)$ the 30 -year Elkins average $(79.2 \mathrm{~cm})$ for the time period (Jan. 1 Aug. 31, 1999). Rainfall in the study area for 1998 and 2000 was very similar to the 30year average of $79.2 \mathrm{~cm}$. The Palmer Drought Index (Palmer 1965) and Standardized Precipitation Index (McKee et al. 1993) both indicated the region was at or near normal hydrologic conditions from January 1 through August 31. (NOAA/NCDC 1999). 
Water temperature averaged over all streams was significantly higher in summer 1999 (June 1-August 31$)\left(15.7^{\circ} \mathrm{C}\right)$ than summer $2000\left(14.8^{\circ} \mathrm{C}\right)(\mathrm{p}<0.0001)($ Table 15$)$. No data were collected in Sawmill Run in 2000 as the temperature logger was stolen. The range in water temperature over all streams was larger during the drought (1999)(9.4-22.9) than during the non-drought period (2000) $\left(9.8-21.2^{\circ} \mathrm{C}\right)$. Highest maximum water temperatures were recorded in Mullenax Run. Average daytime summer (9:00 - 21:00, June 1 - August 31) water temperature at Mullenax Run in 1999 was 17.5 ${ }^{\circ} \mathrm{C}\left(\right.$ range $=9.4-22.9^{\circ} \mathrm{C}$ ) and water temperature exceeded $20.0^{\circ} \mathrm{C}$ for 162 nonconsecutive hours ( $15 \%$ of the time) during the period. No other study stream exceeded $20{ }^{\circ} \mathrm{C}$ for any significant amount of time.

Dissolved oxygen (DO) averaged over all streams from July to September in 1999 was $7.2 \mathrm{mg} / \mathrm{L}(\mathrm{n}=40)$. Percent saturation DO over all streams was $79.9 \%(\mathrm{n}=40)$. Minimum DO concentrations were above $6.0 \mathrm{mg} / \mathrm{L}$ and $64 \%$ saturation in all streams during the drought. Lowest recorded DO concentrations and DO saturations were recorded at Poca Run $(6.0 \mathrm{mg} / \mathrm{L})$ and Long Run (64\% saturation) respectively.

Discharge in summer 1999 was low in all study streams, with some experiencing flow cessation in depositional areas. Discharge over all streams during the drought period was 96\% lower than amounts measured in the non-drought year of 2000 (Table 16) $(\mathrm{p}=0.008)$. Average discharge for all streams in summer 1999 was $0.0027 \mathrm{~m}^{3} / \mathrm{sec}$ (range $=0.0002-0.0041 \mathrm{~m}^{3} / \mathrm{sec}$ ). Considerably higher stream discharges were recorded in summer 2000 under normal precipitation regimes (average $=0.0659 \mathrm{~m}^{3} / \mathrm{sec}$., range $=$ 0.0118-0.2835). 
Habitat. - Drought induced low flows resulted in reduced quantity of habitat for brook trout (Table 17). Average stream wetted width was significantly $(\mathrm{p}<0.0001)$ smaller (32\%) during the drought year than in the non-drought year. Reductions in wetted stream width were primarily attributed to a 54\% loss of riffle area between drought and nondrought years $(\mathrm{p}<0.0001)$. Pool habitat was not significantly lower during drought conditions $(\mathrm{p}=0.3)$. Accompanying decreases in wetted stream area were reductions in average riffle and pool depths, and average maximum pool depths. Riffle habitats were $60 \%$ shallower in the summer 1999 drought period ( $\mathrm{p}<0.0001)$. Average pool depths were $27 \%$ lower during the drought period $(\mathrm{p}<0.0001)$. Average maximum pool depths were also significantly lower $(\mathrm{p}<0.0001)$ during the drought $(24 \%)$. This resulted in a significant decline in over all pool cover quality between 1999 and 2000 (p <0.0001). There was no significant $(\mathrm{p}=0.9)$ difference in the amount of available spawning substrate between the two years.

With low flows and limited precipitation, there was a net gain of sediment $<32$ mm in brook trout spawning substrate from fall 1998 to 1999 (Tables 18 \& 19). There were significant increases $(\mathrm{p}=0.01)$ in amounts of sediment $<0.063 \mathrm{~mm}$ from fall 1998 to fall 1999. No other sediment size classes differed in amounts between years (Table 20).

There were no significant differences in either the $d_{g}$ or $f_{i}$ values between years (Table 21). As both are measures of permeability, it is concluded spawning substrate permeability was not significantly different between the two years despite significantly higher percentages of fine sediment $(<0.063 \mathrm{~mm})$ during the drought year. 
Fish Populations. - Removal efficiency during the population surveys was exceptional. Average electrofishing removal efficiency of brook trout for all streams over the entire study was 97\% (range $=83-100 \%)$. Adult removal efficiency was 96\% (range $=83$ $100 \%$ ) and YOY was $98 \%$ (range $=94-100 \%)$. These data suggest that population estimates were fairly accurate.

With significant reductions in habitat quantity, reduced flows and increasing sediment levels, resident brook trout populations experienced negative population effects. The influence of the drought was delayed for the summer sample period. Summer adult brook trout density over all streams was higher during the drought than the following non-drought year (Table 22) $(\mathrm{p}=0.0003)$. Density of adults was $60 \%$ lower in summer 2000 than densities recorded the previous year at the beginning of the drought. Young of the year density followed the same trend as adults (Table 22). Young of the year density was 67\% lower in summer 2000 than in summer $1999(\mathrm{p}<0.0001)$. Adult density was significantly $(\mathrm{p}=0.003)$ lower in the fall of 1999 than the previous fall of $1998(58 \%)$ (Table 22). However, YOY density was not significantly different between years ( $\mathrm{p}=$ 0.1). Adult and YOY density declined 36\% and 32\% respectively from summer 1999 to fall 1999.

Adult brook trout condition declined slightly (3\%) from summer 1999 to fall 1999 $(\mathrm{p}<0.0001)($ Table 23). Average adult length was not significantly different $(\mathrm{p}=0.2)$ however, body weight was lower over all streams $(4 \%)(\mathrm{p}=0.006)$, indicating little or no net growth of individuals in the population (Table 24, 25). Condition of adults at the end of the drought in fall 1999 was 12\% lower than condition of adults in summer 2000 (p < 0.0001). Average adult condition was 10\% lower in summer 1999 (drought) as compared 
to summer 2000 (non-drought). Adult average length and weight followed similar trends (Tables 24, 25). Brook trout adults in summer 1999 were on average $11 \mathrm{~mm}$ shorter over all streams as compared to adults in summer 2000 ( $\mathrm{p}<0.0001)$. Adult body length was $8 \%$ less in 1999 than was measured the following year under non-drought conditions. Adult body weight was $29 \%$ less during the drought than was measured under nondrought conditions the following year $(\mathrm{p}<0.0001)$.

Body condition of YOY from summer 1999 to fall 1999 declined 16\% ( $\mathrm{p}<$ 0.0001) (Table 23). Comparison between summer 1999 and 2000 showed YOY condition was not significantly different $(\mathrm{p}=0.1)$ between the two summers. However, YOY length and weight were both significantly ( $\mathrm{p}<0.0001$ for both) lower during the drought than in the non-drought period (Table 24, 25). Young of the year length was $11 \%(7 \mathrm{~mm})$ shorter and body weight was $31 \%$ lower during the drought than under nondrought conditions.

Differences in brook trout condition measured in the fall periods were not as great as those found in summer comparisons. Adult and YOY condition were both 2\% and 5\% lower, respectively, under drought conditions ( $\mathrm{p}<0.0001$ for both) (Table 23). Adult length was slightly greater $(\mathrm{p}=0.01)$ during the drought, than in the fall 1998 nondrought year, while body weight did not differ $(\mathrm{p}=0.1)($ Tables 24,25$)$. Young of the year length and weights were significantly different $(\mathrm{p}<0.0001)$ in fall comparison. Body length was $3 \mathrm{~mm}$ or $5 \%$ shorter during the drought year than during fall 1998 (nondrought year). Young of the year body weight was also 19\% lower in the fall under drought conditions. 


\section{Discussion}

Drought impact on stream morphology. - Stream morphology was moderately to severely altered in the 1999 drought (Table 17). Despite extreme flow reductions (- 96\%), stream wetted width, average and maximum water depths, pool cover and pool area were reduced no more than $1 / 3$ that measured under non-drought conditions. In contrast, riffle area and average riffle depth were $54 \%$ and $60 \%$ lower, respectively during drought conditions. Riffle area was reduced more than 25X that of pool area. Kraft (1972) showed decreased water flows reduced surface area to a greater extent in runs than in pools. Larger observed decreases in riffle habitat during the drought are a function of the inherent morphological differences between pools and riffles. With proportionally larger reductions in riffles during the drought period the importance of pool habitat as refuge during low flows is exemplified (Binns 1994). Salmonids forced from shallower habitats seek refuge in pools (Kraft 1972, Elliot and Hurley 1998 in Elliot 2000, Huntingford et al 1999). If such habitat is unavailable, stream carrying capacity is potentially limited as a result (Elliot 1993, Lestelle et al. 1993). Certainly, the overall habitat quantity and quality was reduced in the study streams as a result of the drought creating less favorable conditions for growth and survival.

Flow reductions have been shown to diminish the quality of fish cover within streams (Kraft 1972, Wesche 1974, Hunt 1979, Randolph and White 1984). The lower pool cover ratings observed during drought conditions are likely a consequence of changes in water velocity, undercut bank availability and lower water depths. Water velocity is reduced as water levels decrease (Curtis 1959, Kraft 1972, Wesche 1974). As a result there is less turbulent water for fish to use as cover. Several researchers (Wesche 
1974, Hunt 1979 and Randolph and White 1984) documented loss of wetted overhanging bank cover as water levels declined. Salmonids also utilize the physical depth of the water as a cover mechanism. Body silhouette is less easily visualized as water depth increases and light penetration decreases. Low flow conditions reduce water depths (Curtis 1959, Kraft 1972, Wesche 1974, Titus and Mosegaard 1992) thus lowering cover quality.

Drought affects on brook trout. - Drought-induced morphological changes within the streams had adverse effects upon wild brook trout populations in the headwater streams studied. The influence of drought upon summer brook trout abundance was not apparent until the following year (Table 22), as population surveys were likely conducted (early July) before the full impact of the drought on population density was realized. Fish surviving the summer drought likely had diminished body fat reserves. Researchers have demonstrated fish lipid reserves are critical to overwinter survival (Thompson et al. 1991, Hutchings 1994, Sogard and Olla 2000). Further, smaller fish utilize lipid reserves at a higher rate (Miranda and Hubbard 1994). The observed lag in drought effect on brook trout density may therefore be a consequence of lower winter survival attributed to reduced body condition entering the winter.

Hunt (1979) showed fall brook trout biomass was a positive function of summer discharge levels. In this study there were reductions in both adult (36\%) and YOY (32\%) brook trout abundance from the summer 1999 to the fall 1999 survey (Table 22). However, reductions in abundance attributed to the impacts of the drought and those from natural mortality could not be isolated. 
There were significantly fewer YOY brook trout in summer 2000 (67\% fewer) than were captured the previous summer at the beginning of the drought (Table 22). This is perhaps a function of one or more factors present during the fall 1999 spawning period. First, there were significantly fewer adults present that could potentially spawn in fall 1999. Elliot et al. (1997) reported brown trout egg production was reduced $73-83 \%$ as a result of adult female loss during drought episodes. In addition to fewer adults, those present were of lower body condition, which may have resulted in a number of adults failing to produce (Wydoski and Cooper 1965) or producing fewer gametes. Adams and Huntingford (1997) demonstrated arctic char (Salvelinus alpinus) egg production was positively related to lipid reserves. Additionally, it is possible eggs produced by poorer condition brook trout were of lower quality and had lower survival to emergence success. Laine and Rajasilta (1999) showed Baltic herring (Clupea harengus membrasi) egg survival and hatching success was positively related to pre-spawn female body condition. Despite no significant decreases in the amount of suitable spawning substrate, spawning areas may have become inaccessible to spawning fish due to low water levels (Titus and Mosegaard 1992). Each of these factors potentially contributed to the observed reduction in YOY brook trout abundance following the drought.

As expected, adult body condition was significantly lower during the drought than in the following non-drought year (10\% lower) (Table 23$)$. The $10 \%$ reduction in body condition does not adequately reflect the impact drought had on overall population fitness. The major impact was loss of body weight and not length during the drought. Adults were 8\% shorter in summer 1999 than summer 2000, however body weight was $29 \%$ less. This shows reductions in adult body condition were attributed primarily to loss 
of body weight. Further, true body condition was likely less than measured because as fish lose lipids they uptake water (Sogard and Olla 2000) and thus, condition as measured by Fulton, would tend to not relate well to body energy levels.

YOY summer condition was not significantly different between the drought and the non-drought years. These somewhat counterintuitive findings may be attributed to proportional decreases in length and weight between the two years, resulting in similar condition indices. Like adults, the decline in YOY body condition was primarily a function of a $31 \%$ decrease in body weight and to a lesser extent reductions in body length (11\% lower).

The reported reductions in body condition, length and weight are likely underestimates of the true impact the drought had on population fitness. Adults measured in summer of 2000 (post-drought) were either YOY or adults during the previous year's drought. Undoubtedly adult brook trout entering the 2000 growing season were shorter and weighed less than if they had not suffered through drought conditions. Moreover, there is an inherent bias towards higher body condition, as fish that died (presumably of lowest body condition) were not measured.

Mechanisms responsible for observed population changes. - Most sediment sizes below $32 \mathrm{~mm}$ increased in percentage by weight within brook trout spawning substrate over the drought period (Tables $18 \& 19$ ). Others have reported increased siltation in streams during low flow periods (Kraft 1972, Wright 1992). Statistical analysis of the empirical data showed significant $(\mathrm{p}=0.01)$ increases in the amount of fine sediment $<0.063 \mathrm{~mm}$ between the fall 1998 and fall 1999 substrate samples ( 0.9 to $1.3 \%$ by weight) (Table 20). 
The biological significance of such a small increase is debatable as measures of substrate permeability $\left(d_{g}\right.$ and $\left.f_{i}\right)$ (Table 21) did not significantly differ between the two years. Substrate permeability is directly related to salmonid survival to emergence (Cooper 1965, Peterson 1978, Reiser and White 1988). Theoretically, this would insinuate survival to emergence from the gravel would be similar in both years given all other variables held constant. Therefore, measured increases in fine sediment $<0.063 \mathrm{~mm}$ during the drought were likely not of biological importance in the systems studied, and presumably not responsible for reduced brook trout numbers and condition.

Average and maximum stream water temperatures (Table 15) were generally well below levels deemed critical to salmonid survival during the drought period (Fry et al. 1947, MacCrimmon and Campbell 1969, Meisner 1990). With the exception of one stream, average water temperatures were predominately within the optimal range for brook trout (Bjornn and Reiser 1991). Overall, this suggests water temperature was not the mechanism exacting reductions in brook trout condition and abundance during the drought period.

Although dissolved oxygen concentrations were not intensively measured, we believe levels did not negatively impact brook trout populations. Minimum DO levels $(6.0 \mathrm{mg} / \mathrm{L})$ measured over all streams never approached lethal concentrations. Spoor (1990) demonstrated brook trout avoidance of areas containing $4.0 \mathrm{mg} / \mathrm{L}$ dissolved oxygen. He concluded brook trout preferred oxygen levels above $5.0 \mathrm{mg} / \mathrm{L}$. Our data suggest dissolved oxygen levels within the study streams were not the cause of reduced brook condition and abundance over the drought period. 
With both water temperature and dissolved oxygen remaining generally above levels suitable for brook trout survival, and fine sediment differences appearing to be no more important during the drought than non-drought year, I propose drought-induced changes in the physical habitat were the causal mechanism behind the observed declines in brook trout condition and abundance. The reductions in available habitat may have created conditions by which a spatially limited food source negatively influenced brook trout growth and/or survival as demonstrated for other salmonids (Mason and Chapman 1965, Chapman 1966, Egglishaw 1967, Jonsson et al 1998). Salmonids are territorial, establishing and defending territories early in life (Mason and Chapman 1965, Chapman 1966, Allen 1969, LeCren 1973, Slaney and Northcote 1974, Mason 1976, Elliot 1990, Grant and Kramer 1990). With less wetted habitat available there are fewer available “optimal foraging” locations (Fausch 1984). Salmonids not holding a feeding territory tend to experience reduced growth and survival (Chapman 1966, Elliot 1990) and/or are forced from the area by territorial holding individuals (Mason 1976). Symons (1971) showed that in the absence of a feeding territory, juvenile Atlantic salmon grew at a rate two-thirds that of fish holding a feeding territory. Therefore, brook trout in the streams studied likely experienced reduced growth and survival during the 1999 drought as a result of the documented reductions in habitat availability.

Compounding decreased territorial space, reductions in invertebrate prey density and drift rates presumably aided in the development of conditions whereby food was spatially restricted. Prey availability is a function of density (Allen 1969) and drift rate. Organisms in the drift are the principal food source of stream salmonids (Chapman 1966, Elliot 1973) thus reduced flow rates during the drought (96\% decline in discharge) would 
tend to diminish prey delivery rates. Riffle areas are the primary source of food production for stream salmonids (Waters 1982, Hawkins et al. 1983). Observed decreases in riffle area in this study (- 54\%) would have certainly resulted in reductions in salmonid food supply. Kaller (2000), conducting macroinvertebrate research in the same streams used in this study, reported significant declines in invertebrate density over the drought period. We suggest significant reduction in food producing area, reductions in macroinvertebrate abundance, low flows, and an overall decline in available habitat related to the drought, caused the observed decreases in salmonid densities and overall body condition.

Sources of drought-induced mortality. - Lower body condition following the drought may have substantially lowered overwinter survival of brook trout. Fish surviving the summer and fall drought may have died prematurely during the winter months, following the rigors of spawning which substantially deplete lipid reserves crucial to overwinter survival (Hutchings 1994). Salmonid survival during the winter is a function of fish size at the onset of winter (Smith and Griffith 1994). Quinn and Peterson (1996) reported larger juvenile coho salmon (Oncorhynchus kisutch) overwinter survival rates were significantly higher than those of smaller individuals. Meyer and Griffith (1997) reported that in situ cage experiments, brook trout overwinter survival was greater for larger (mean $\mathrm{TL}=124 \mathrm{~mm}$ ) fish than smaller individuals (mean $\mathrm{TL}=101 \mathrm{~mm}$ ). If individuals were smaller as a result of the drought, then overwinter survival was potentially below normal. 
Ascertaining if reductions in brook trout density during the drought were attributed to mortality or emigration from the headwater systems is difficult. Researchers have suggested salmonids tend to migrate upstream as water levels decrease (Kraft 1972, Huntingford et al. 1999). In an artificial stream system, Huntingford et al. (1999) reported $74 \%$ of juvenile Atlantic salmon (Salmo salar) moved upstream in response to falling water levels. This behavioral response may prevent entrapment in areas of unsuitable water temperature downstream. However, Elliot and Hurley (1998) reported limited upstream or downstream movement of brown trout during drought periods. If this were the case for brook trout in this study, then mortality, and not emigration, would likely have been the cause of observed declines following the drought. Brook trout possibly fleeing drought conditions would have been restricted in four of the seven streams by a number of dewatered riffle habitats. Based on the lack of research indicating downstream migration of salmonids in response to reduced water levels, and the observed obstacles to migration found in our streams, I speculate the observed reductions in brook trout density were primarily a function of mortality within the study streams, and perhaps to a lesser extent emigration out the study reaches.

Other sources of mortality apart from starvation are cannibalism and predation. As water levels are reduced, YOY are often forced into areas occupied by adults (Binns 1994, Herger et al. 1996). This potentially increases the chance for cannibalism to occur. However, we speculate cannibalism was not a major source of YOY mortality in the systems studied. No significant relation was evident between YOY and adult brook trout density in either summer $1999(\mathrm{p}=0.9)$ or fall $1999(\mathrm{p}=0.6)$. This would suggest the presence of adults had no influence upon YOY density. Stomach analysis of 600 adult 
brook trout in several streams in the region found only one instance of YOY brook trout as a prey item (J. Sweka, unpublished data). These findings are comparable to those of White and Hunt (1969) who found no YOY in the stomach contents of 1400 adult brook trout. They further concluded from analysis of a 17-year data set, that cannibalism was not an important mechanism in the regulation of YOY brook trout density.

Additionally, the possibility exists that as water levels decrease, fish become more susceptible to mammalian and avian predation. However, personal observation over the course of the two year study would suggest predation of brook trout was not a significant source of mortality during the drought. I made no direct observation of piscivorous bird species in the study area. Raccoons were present, yet tracks and scat were not often noted, and scat was never observed to have fish remains within it. These observations are by no means quantitative thus, the extent to which predation occurred during the study is generally unknown and warrants further investigation.

Another source of potential mortality was that from anglers. Fish were perhaps more susceptible to harvest and increased hooking mortality upon release, as fish were presumably under stress from the drought-induced low flows. Based on field observation during the summer months, fishing pressure was light to non-existent in most streams and likely not a major source of mortality.

Summary and management implications. - Proportionally larger decreases in riffles relative to pool habitat, and reduced flow velocity potentially combined to limit macroinvertebrate production and subsequent availability. Consequently, brook trout confined to pool habitats were likely forced to compete for spatially restricted food 
resources. I believe observed decreases in brook trout density and body condition following the drought were a function of spatially limited food resources and not a function of degraded water quality or mass emigration from the systems.

Those tasked with the management of headwater fisheries should consider the implications of periodic drought on brook trout population dynamics. The species is relatively short-lived, (McFadden 1961) with headwater populations generally comprised of individuals less than three years of age (Morgan and Robinette 1978). As a result, few reproductive age classes are present at any one time. The observed reductions in adult brook trout in this study (60\% decline between summer 1999 and 2000), suggest reproductive potential in the post-drought period would be substantially diminished, making the population more susceptible to overharvest. To expedite the recovery of headwater brook trout populations after a drought, fisheries managers should consider implementing short-term $(<1$-year) harvest regulations to minimize loss of adult fish the year following a drought. A creel limit is perhaps one approach by which angler harvest of reproductive fish could be reduced, while minimizing angler dissatisfaction, that may be associated with more liberal management techniques such as season closure. Reducing harvest of adult fish the year following a drought would likely expedite recovery of the population through greater egg production. Such a practice would further aid in lessening long-term suppression of population size associated with repeated stochastic events. 
Table 14. Total precipitation recorded in Bartow and Elkins, WV between January 1 and August 31 for 1998, 1999 and 2000.

\begin{tabular}{ccc}
\hline & \multicolumn{2}{c}{ Location of observatory } \\
& Bartow (study area) & Elkins \\
Year & $(\mathrm{cm})$ & $(\mathrm{cm})$ \\
\hline 1998 & 78.0 & 82.0 \\
1999 & 58.6 & 62.5 \\
2000 & 74.8 & 78.9 \\
30-year average & $\mathrm{n} / \mathrm{a}$ & 79.2 \\
\hline $\mathrm{n} / \mathrm{a}=$ No long-term data available. & &
\end{tabular}

n/a = No long-term data available. 
Table 15. Mean daytime (9:00 - 21:00) water temperature $\left({ }^{\circ} \mathrm{C}\right)$ recorded hourly from June through August for all study streams in 1999 and 2000 (range in parentheses).

\begin{tabular}{|c|c|c|}
\hline Stream name & 1999 & 2000 \\
\hline \multirow[t]{2}{*}{ Elleber Run } & 15.2 & 13.7 \\
\hline & $(10.4-19.1)$ & $(9.8-15.9)$ \\
\hline \multirow[t]{2}{*}{ Lick Run } & 16.0 & 15.1 \\
\hline & $(10.3-19.9)$ & $(10.1-18.4)$ \\
\hline \multirow[t]{2}{*}{ Little Low Place } & 14.8 & 14.3 \\
\hline & $(10.9-17.9)$ & $(10.3-16.5)$ \\
\hline \multirow[t]{2}{*}{ Long Run } & 15.6 & 15.3 \\
\hline & $(10.6-20.0)$ & $(10.6-18.1)$ \\
\hline \multirow[t]{2}{*}{ Mullenax Run } & 17.4 & 16.6 \\
\hline & $(9.4-22.9)$ & $(9.9-21.2)$ \\
\hline \multirow[t]{2}{*}{ Poca Run } & 14.9 & 14.2 \\
\hline & $(10.1-18.4)$ & $(9.8-17.2)$ \\
\hline \multirow[t]{2}{*}{ Sawmill Run } & 16.4 & no data \\
\hline & $(10.4-20.2)$ & \\
\hline Total mean & 15.7 & 14.8 \\
\hline$( \pm 95 \% \mathrm{CI})$ & \pm 0.05 & \pm 0.04 \\
\hline
\end{tabular}


Table 16. Stream discharge in each stream for summer 1999 and summer 2000.

\begin{tabular}{ccc}
\hline $\begin{array}{c}\text { Stream } \\
\text { name }\end{array}$ & $\begin{array}{c}\text { Summer 1999 } \\
\left(\mathrm{m}^{3} / \mathrm{sec} .\right)\end{array}$ & $\begin{array}{c}\text { Summer 2000 } \\
\left(\mathrm{m}^{3} / \mathrm{sec} .\right)\end{array}$ \\
\hline Elleber Run & 0.0030 & 0.2835 \\
Lick Run & 0.0002 & 0.0136 \\
Little Low Place & 0.0041 & 0.0274 \\
Long Run & 0.0014 & 0.0393 \\
Mullenax Run & 0.0033 & 0.0693 \\
Poca Run & 0.0029 & 0.0167 \\
Sawmill Run & 0.0041 & 0.0118 \\
\hline
\end{tabular}


Table 17. Mean physical habitat parameters over all streams for both years. Significant differences denoted with an asterix $(*)$. (95\% CI next to mean).

Sample period

Habitat parameter $\quad 1999 \quad 2000 \quad \%$ difference between years

\begin{tabular}{|c|c|c|c|}
\hline $\begin{array}{l}\text { Average stream wetted width } \\
\qquad(\mathrm{m})\end{array}$ & $\begin{array}{l}1.7 \pm 0.1 \\
\mathrm{n}=317\end{array}$ & $\begin{array}{l}2.5 \pm 0.1 \\
\mathrm{n}=293\end{array}$ & $-32 \% *$ \\
\hline $\begin{array}{l}\text { Average riffle depth } \\
\qquad(\mathrm{cm})\end{array}$ & $\begin{array}{l}4.0 \pm 0.3 \\
n=141\end{array}$ & $\begin{array}{l}10.0 \pm 0.7 \\
\mathrm{n}=129\end{array}$ & $-60 \% *$ \\
\hline $\begin{array}{l}\text { Average pool depth } \\
\qquad(\mathrm{cm})\end{array}$ & $\begin{array}{l}16.0 \pm 1.1 \\
\mathrm{n}=134\end{array}$ & $\begin{array}{c}22.0 \pm 1.3 \\
\mathrm{n}=138\end{array}$ & $-27 \% *$ \\
\hline $\begin{array}{l}\text { Average maximum pool depth } \\
\qquad(\mathrm{cm})\end{array}$ & $\begin{array}{l}25.0 \pm 1.8 \\
\mathrm{n}=140\end{array}$ & $\begin{array}{c}33.0 \pm 1.9 \\
\mathrm{n}=138\end{array}$ & $-24 \% *$ \\
\hline $\begin{array}{l}\text { Average pool rating } \\
\qquad(1-5)\end{array}$ & $\begin{array}{l}2.3 \pm 0.2 \\
n=140\end{array}$ & $\begin{array}{l}3.0 \pm 0.3 \\
\mathrm{n}=138\end{array}$ & $-23 \% *$ \\
\hline $\begin{array}{l}\text { Pool area } \\
\qquad\left(\mathrm{m}^{2}\right)\end{array}$ & $\begin{array}{l}9.0 \pm 1.4 \\
n=134\end{array}$ & $\begin{array}{l}9.2 \pm 1.4 \\
\mathrm{n}=138\end{array}$ & $-2 \%$ \\
\hline $\begin{array}{l}\text { Riffle area } \\
\qquad\left(\mathrm{m}^{2}\right)\end{array}$ & $\begin{array}{l}12.8 \pm 1.7 \\
\mathrm{n}=141\end{array}$ & $\begin{array}{c}28.0 \pm 5.4 \\
\mathrm{n}=129\end{array}$ & $-54 \% *$ \\
\hline $\begin{array}{c}\text { Spawning area } \\
\left(\mathrm{m}^{2}\right)\end{array}$ & $\begin{array}{l}9.9 \pm 1.3 \\
n=317\end{array}$ & $\begin{array}{c}10.4 \pm 3.5 \\
n=293\end{array}$ & $-5 \%$ \\
\hline
\end{tabular}


Table 18. Mean percent composition of each sediment size class for spawning substrate collected in both years (95\% CI below mean).

\begin{tabular}{|c|c|c|c|c|c|c|c|c|c|c|c|}
\hline \multirow{3}{*}{$\begin{array}{l}\text { Sample } \\
\text { period }\end{array}$} & \multicolumn{11}{|c|}{ Sieve mesh size $(\mathrm{mm})$} \\
\hline & $>32$ & $16-<32$ & $8-<16$ & $4-<8$ & $2-<4$ & $1-<2$ & $0.5-<1$ & $0.25-$ & $0.125-$ & $0.063-$ & $<0.063$ \\
\hline & & & & & & & & $<0.5$ & $<0.25$ & $<0.125$ & \\
\hline Fall 1998 & 26.7 & 16.0 & 15.4 & 14.1 & 9.5 & 7.1 & 4.1 & 2.7 & 2.4 & 0.9 & 0.9 \\
\hline $\mathrm{N}=30$ & \pm 7.3 & \pm 3.3 & \pm 2.4 & \pm 2.7 & \pm 2.2 & \pm 1.4 & \pm 0.8 & \pm 0.7 & \pm 0.8 & \pm 0.3 & \pm 0.2 \\
\hline Fall 1999 & 21.0 & 18.1 & 17.3 & 14.2 & 10.1 & 6.3 & 4.5 & 3.3 & 2.8 & 1.1 & 1.3 \\
\hline $\mathrm{N}=39$ & \pm 5.6 & \pm 2.5 & \pm 2.4 & \pm 1.8 & \pm 1.8 & \pm 1.2 & \pm 0.9 & \pm 0.9 & \pm 0.9 & \pm 0.3 & \pm 0.2 \\
\hline
\end{tabular}


Table 19. Mean percent less than for each sediment size class for spawning substrate collected in both years (95\% CI below mean).

\begin{tabular}{|c|c|c|c|c|c|c|c|c|c|c|}
\hline \multirow[b]{2}{*}{ Sample period } & \multicolumn{10}{|c|}{ Sieve mesh size $(\mathrm{mm})$} \\
\hline & $<32$ & $<16$ & $<8$ & $<4$ & $<2$ & $<1$ & $<0.5$ & $<0.25$ & $<0.125$ & $<0.063$ \\
\hline Fall 1998 & 73.3 & 57.2 & 41.8 & 27.7 & 18.2 & 11.1 & 7.0 & 4.3 & 1.8 & 0.9 \\
\hline $\mathrm{N}=30$ & \pm 7.3 & \pm 8.3 & \pm 6.9 & \pm 4.9 & \pm 3.4 & \pm 2.4 & \pm 1.8 & \pm 1.0 & \pm 0.4 & \pm 0.2 \\
\hline Fall 1999 & 79.0 & 60.9 & 43.6 & 29.4 & 19.2 & 12.9 & 8.4 & 5.1 & 2.3 & 1.3 \\
\hline $\mathrm{N}=39$ & \pm 5.6 & \pm 6.6 & \pm 6.0 & \pm 4.7 & \pm 3.5 & \pm 2.8 & \pm 2.2 & \pm 1.4 & \pm 0.5 & \pm 0.2 \\
\hline
\end{tabular}


Table 20. Statistical comparison of brook trout spawning substrate collected in fall 1998 and 1999. Significant differences are denoted with an asterix $\left(^{*}\right) .(+)=$ increase in percentage from 1998 to 1999. $(-)=$ decrease in percentage from 1998 to 1999.

\begin{tabular}{cc}
\hline $\begin{array}{c}\text { Sieve mesh size } \\
(\mathrm{mm})\end{array}$ & $\begin{array}{c}\text { Direction of } \\
\text { change }\end{array}$ \\
\hline$>32$ & $(-)$ \\
$8-16$ & $(+)$ \\
$4-8$ & $(+)$ \\
$2-4$ & $(+)$ \\
$1-2$ & $(-)$ \\
$0.5-1$ & $(+)$ \\
$0.25-0.5$ & $(+)$ \\
$0.125-0.25$ & $(+)$ \\
$0.063-0.125$ & $(+)$ \\
$<0.063$ & $(+)$ \\
\hline
\end{tabular}


Table 21. Average geometric mean diameter $\left(d_{g}\right)$ and fredle index $\left(f_{i}\right)$ value for spawning substrate collected in both years (95\% CI next to mean).

\begin{tabular}{|c|c|c|c|c|}
\hline & \multicolumn{2}{|c|}{ Fall $1998(\mathrm{n}=30)$} & \multicolumn{2}{|c|}{ Fall $1999(\mathrm{n}=39)$} \\
\hline & $\begin{array}{c}d_{g} \\
(\mathrm{~mm})\end{array}$ & $f_{i}$ & $\begin{array}{c}d_{g} \\
(\mathrm{~mm})\end{array}$ & $f_{i}$ \\
\hline $\begin{array}{l}\text { Spawning } \\
\text { substrate }\end{array}$ & $5.2 \pm 0.7$ & $2.1 \pm 0.5$ & $5.4 \pm 0.7$ & $2.2 \pm 0.4$ \\
\hline
\end{tabular}


Table 22. Total brook trout density (fish/ha) for all streams for each sample period.

\begin{tabular}{|c|c|c|c|c|}
\hline & \multicolumn{4}{|c|}{ Sample period } \\
\hline & Fall 1998 & Fall 1999 & Summer 1999 & Summer 2000 \\
\hline Age & (non-drought) & (drought) & (drought) & (non-drought) \\
\hline Adult & 21,113 & $12,647^{1}$ & 19,692 & 7,957 \\
\hline YOY & 5,214 & $8,197^{1}$ & 12,017 & 3,922 \\
\hline \multicolumn{5}{|c|}{$1=$ fall 1999 total adult and YOY density without Sawmill Run is 8,797 and 7,577 } \\
\hline \multicolumn{5}{|c|}{ fish/ha, respectively. These numbers were used for comparison of fall 1998 and fall } \\
\hline
\end{tabular}


Table 23. Mean adult and YOY brook trout condition for all streams for each sample period (95\% CI in parentheses).

\begin{tabular}{|c|c|c|c|c|}
\hline \multirow[b]{3}{*}{ Age } & \multicolumn{4}{|c|}{ Sample period } \\
\hline & Fall 1998 & Fall 1999 & Summer 1999 & Summer 2000 \\
\hline & (non-drought) & (drought) & (drought) & (non-drought) \\
\hline \multirow[t]{3}{*}{ Adult } & $9.029 \mathrm{E}-6$ & $8.857 \mathrm{E}-6$ & $9.095 \mathrm{E}-6$ & 10.103 E-6 \\
\hline & $(8.875-9.183 \mathrm{E}-6)$ & (8.311-8.824 E-6) & (9.022-9.168 E-6) & (9.637-10.569 E-6) \\
\hline & $\mathrm{n}=521$ & $n=648$ & $\mathrm{n}=1040$ & $\mathrm{n}=608$ \\
\hline \multirow[t]{3}{*}{ YOY } & 9.816 E-6 & 9.285 E-6 & 11.010 E-6 & 10.958 E-6 \\
\hline & (9.327-10.304 E-6) & (9.074-9.497 E-6) & (10.792-11.227 E-6) & (10.739-11.177 E-6) \\
\hline & $\mathrm{n}=148$ & $n=397$ & $\mathrm{n}=581$ & $\mathrm{n}=301$ \\
\hline
\end{tabular}


Table 24. Mean adult and YOY brook trout length for all streams for each sample period (95\% CI below mean).

\begin{tabular}{lcccc}
\hline & & \multicolumn{2}{c}{ Sample period } & \\
Fall 1998 & Fall 1999 & Summer 1999 & Summer 2000 \\
Age & (non-drought) & (drought) & (drought) & (non-drought) \\
\hline Adult & $121 \pm 2$ & $124 \pm 1$ & $125 \pm 2$ & $136 \pm 2$ \\
$(\mathrm{~mm})$ & $\mathrm{n}=521$ & $\mathrm{n}=648$ & $\mathrm{n}=1040$ & $\mathrm{n}=608$ \\
YOY & $70 \pm 2$ & $67 \pm 1$ & $58 \pm 1$ & $65 \pm 1$ \\
$(\mathrm{~mm})$ & $\mathrm{n}=148$ & $\mathrm{n}=397$ & $\mathrm{n}=581$ & $\mathrm{n}=301$ \\
\hline
\end{tabular}


Table 25. Mean adult and YOY brook trout weight for all streams for each sample period (95\% CI next to mean).

\begin{tabular}{lcccc}
\hline & & \multicolumn{2}{c}{ Sample period } & \\
Fall 1998 & Fall 1999 & Summer 1999 & Summer 2000 \\
Age & (non-drought) & (drought) & (drought) & (non-drought) \\
\hline Adult & $17.8 \pm 1.1$ & $18.9 \pm 0.6$ & $19.7 \pm 0.6$ & $27.9 \pm 1.6$ \\
$(\mathrm{gm})$ & $\mathrm{n}=521$ & $\mathrm{n}=648$ & $\mathrm{n}=1040$ & $\mathrm{n}=608$ \\
YOY & $3.6 \pm 0.2$ & $2.9 \pm 0.1$ & $2.2 \pm 0.1$ & $3.2 \pm 0.1$ \\
$(\mathrm{gm})$ & $\mathrm{n}=148$ & $\mathrm{n}=397$ & $\mathrm{n}=581$ & $\mathrm{n}=301$ \\
\hline
\end{tabular}




\section{Chapter 4:}

\section{Executive summary}

Brook trout $(<250 \mathrm{~mm})$ generally spawned in substrate $<32 \mathrm{~mm}$. Approximately $75 \%$ of material in non-redd samples were $<32 \mathrm{~mm}$ in size. Substrate $<4 \mathrm{~mm}$ accounted for an appreciable percentage of spawning substrate (>25\% in non-redds). This perhaps indicates the percent fine sediment $<4.0 \mathrm{~mm}$ may not adequately define "fine sediment" as it pertains to smaller Appalachian brook trout. Therefore, sediment sizes smaller than $4.0 \mathrm{~mm}$ should be considered in establishing criteria for fine sediment as it applies to the smaller brook found in these systems.

Adult brook trout (mean $\mathrm{TL}=121 \mathrm{~mm}$ ) were able to significantly reduce the amount of fine sediment $<2 \mathrm{~mm}$ from the egg pocket and tailspill during the redd construction process as demonstrated by Young et al. (1989). Therefore eggs were presumably deposited in substrate "cleaner" than the background material. Alteration of the spawning substrate likely created higher observed variability in measures of percent composition. Researchers and managers should therefore consider collecting samples from the surrounding substrate instead of directly from the redd. This potentially provides measures better representing sediment conditions within a stream and during the embryonic period.

In one of the two years of study, brook trout production (per-capita-birth rate) was related to substrate permeability. In that same year, univariate analyses indicated YOY abundance was inversely associated with the percentage of fine sediment $<0.063 \mathrm{~mm}$. The lack of relation in YOY abundance to other habitat variables measured, suggests fine sediment is potentially a primary factor limiting brook trout production 
in years of normal stream flow. Conclusions were supported by the MLR analysis. Multiple linear regression analysis of fine sediment $(<0.063 \mathrm{~mm})$ and average water depth indicated fine sediment was more important than water depth in determining YOY abundance. These data suggest substrate, especially of the smaller grain sizes, was influencing YOY abundance. The causal mechanism behind the relationship was not identified, but it is presumed fine sediment was decreasing survival in the intragravel stage and/or affecting food resources, subsequently lowering YOY survivorship.

Previous salmonid research provides evidence supporting the finest sediment grain sizes as those most likely causing lower survival during the intragravel period (Peterson and Metcalfe 1981, Reiser and White 1988). Statistical limitations prevented identification of a precise sediment size class most negatively influencing YOY abundance in this study. However, a sediment size range can be deduced from the analyses. Sediment $<1.0 \mathrm{~mm}$ was inversely related to substrate permeability. Multiple linear regression analysis showed sediment sizes between $0.25-1.0 \mathrm{~mm}$ explained the greatest proportion of variation in substrate permeability as measured by the $f_{i}$ and $d_{g}$. In combination with sediment sizes directly influencing YOY abundance (percent $<0.063$ $\mathrm{mm}$ ), the results suggest fine sediment sizes between $0.063 \mathrm{~mm}$ and $1.0 \mathrm{~mm}$ are our best estimate for a critical sediment grain size influencing brook trout abundance in the headwater systems assessed.

Comparison of sediment levels measured in the present study with amounts deemed critical by other investigators reveals sediment amounts are at, or slightly below levels expected to reduce brook trout survival (Hausle and Coble 1976, Argent and Flebbe 1999). This further substantiates our conclusions that fine sediment $(<0.063 \mathrm{~mm})$ 
was influencing brook trout production in the first year of study. Three-fold decreases in YOY brook trout abundance were observed in year 1 of the study at levels of fine sediment $(<0.063 \mathrm{~mm})$ between $0.6-1.0 \%$ in the spawning substrate (non-redd samples). These findings would suggest that profound negative impacts to brook trout populations may be incurred, if fine sediment $(<0.063 \mathrm{~mm})$ levels exceed $0.6-1.0 \%$ of the spawning bed material.

Stream gradient was demonstrated to have a negative influence upon fine sediment levels in the streams studied. However, it is speculated that for stream gradient to have influence upon fine sediment, water flows must be adequate enough to "flush" the system (Adams and Beschta 1980). Significant increases in fine sediment $(<0.063$ $\mathrm{mm}$ ) were noted over the drought period, and were potentially a function of droughtinduced low flows. However the increase was deemed to not be of biological significance, as substrate permeability was not significantly different between years. Nevertheless, the observed sediment/gradient relationship suggests impacts of increased sedimentation may potentially be mitigated in steeper gradient stream systems.

The significant relationship between fine sediment and stream gradient complicates inferences drawn about the influence of fine sediment on YOY abundance. Intercorrelation between these variables prevented solid conclusion as to which variable, fine sediment or stream gradient, carried the greatest influential weight in governing YOY abundance. However, the lack of relation of YOY abundance directly to stream gradient in year 1 of the study, would suggest fine sediment influences were of greater importance. 
Adult and total brook trout abundance was a positive function of average water depth, average maximum pool depth, pool area, amount of spawning substrate, and stream gradient in the first year of this study. A number of collinear relationships existed between these variables leaving average water depth, pool area and stream gradient for further MLR analysis. Multiple linear regression analyses identified average stream water depth as the primary mechanism in determination of adult and total brook trout abundance. The development of a relationship between adult and total brook trout abundance and pool area at the end of the drought period emphasizes the importance of pool habitat in the study streams. However, we surmise adult brook trout abundance, though significant for several variables, is principally an underlying factor of stream discharge. Water depth and pool area, were both positively related to summer stream discharge. The lack of direct relation between stream discharge and adult brook trout abundance is speculated to be an artifact of only measuring it once a year.

Support for stream discharge as one mechanism (sediment being the other) governing brook trout abundance is provided in the quantitative assessment of the 1999 drought. Spatially limited food resource were the suggested cause for decreases in brook trout abundance during the drought episode. Extremely low stream discharge and associated low water velocities reduced habitat availability, and greatly diminished riffle area, the primary source of food production for stream salmonids (Waters 1982, Hawkins et al. 1983). With less area for food production, and low flows presumably decreasing invertebrate drift rates, brook trout forced into smaller habitats were likely compelled to compete for limited food resources. Young of the year abundance in the post-drought period (summer 2000) was considerably lower as compared to YOY density the previous 
summer. Adult abundance also declined following the drought, reducing the potential spawning stock. Thus, we believe drought impact upon adult fish caused the observed decrease in YOY density following the drought.

Catastrophic events such as droughts and floods (McCullough 1997) appear to have a profound effect on the population dynamics in headwater stream systems. The general lack of relation to habitat variables and substrate composition in the post-drought period (2000) is thought to be attributed to the drought weakening our ability to detect and/or overpowering the influence of other variables.

In summary, fine sediment and stream discharge are suggested to both be influential as determinants of brook trout population size. As the finest sediment analyzed $(<0.063 \mathrm{~mm})$ was demonstrated to inversely influence YOY abundance, and with roads as a documented source of finer sediments, resource managers should consider the impact of interior forest roads in the management of brook trout populations. Summer adult brook trout abundance in year 1 was positively related to YOY abundance in the previous fall. Therefore, reduced survival of YOY as a consequence of negative fine sediment impacts potentially has implications for adult abundance. In addition, stream discharge at low flow periods should be considered in evaluation of a stream's potential for brook trout production. Further, managers should consider short-term $(<1$ year) harvest regulations in the aftermath of catastrophic events such as droughts. This would likely minimize the potential for overharvest of reproductive fish, and abet population recovery to pre-drought conditions. 


\section{Literature cited}

Adams, J.N. and R.L. Beschta. 1980. Gravel bed composition in Oregon coastal streams. Canadian Journal of Fisheries and Aquatic Sciences 37:1514-1521.

Adams, C.E. and F.A. Huntingford. 1997. Growth, maturation and reproductive investment in Arctic char. Journal of Fish Biology 51(4):750-759.

Allen, R.K. 1969. Limitations on production in salmonid populations in streams. In: T.G. Northcote, editor. Symposium on salmon and trout in streams. . H.R. MacMillan Lectures in Fisheries. University of British Columbia, Vancouver, Canada.

Anderson, R.O. and S.J. Gutreuter. 1983. Length, weight, and associated structural indices. Pages 283-300 in L.A. Nielsen and D.L. Johnson, editors. Fisheries Techniques. American Fisheries Society, Bethesda, Maryland.

Angradi, T.R. and M.R. Vinson. 1996. Fine sediment - aquatic macroinvertebrate community relationships in headwater streams of the Monongahela National Forest: a report to the Forest Supervisor. U.S.D.A Forest Service, Northeast Forest Experiment station, Parsons, WV.

Argent, D.G. and P.A. Flebbe. 1999. Fine sediment effects on brook trout eggs in laboratory streams. Fisheries Research 39:253-262.

Armour, C.L., K.P. Burnham, and W.S. Platts. 1983. Field methods and statistical analyses for monitoring small salmonid streams. U.S. Fish and Wildlife Service FWS/OBS-83/33. 200 pp.

Bams, R.A. 1969. Adaptations of sockeye salmon associated with incubation in stream gravels. Pages 71-81 in T.G. Northcote, editor. Symposium on salmon and trout in streams. . H.R. MacMillan Lectures in Fisheries. University of British Columbia, Vancouver, Canada.

Beard, T.D. and R.F. Carline. 1991. Influence of spawning and other stream habitat features on spatial variability of wild brown trout. Transactions of the American Fisheries Society 120: 711-722.

Bell, V.A., J.M. Elliot, R.J. and Moore. 2000. Modeling the effects of drought on the population of brown trout in Black Brows Beck. Ecological Modeling 127:141159.

Beschta, R.L. and W.L. Jackson. 1979. The intrusion of fine sediments into a stable gravel bed. Journal of Fisheries Research Board of Canada 36:204-210. 
Bianchi, D.R. 1963. The effects of sedimentation on egg survival of rainbow trout and cutthroat trout. Master's Thesis, Montana State College, Bozeman, Montana.

Binns, N.A. 1994. Long-term responses of trout and macrohabitats to habitat management in a Wyoming headwater stream. North American Journal of Fisheries Management 14:87-98.

Bisson, P.A., J.L. Nielsen, R.A. Palmason, and L.E. Grove. 1982. A system of naming habitat types in small streams, with examples of habitat utilization by salmonids during low streamflow. Pages 62-73 in N.B. Armantrout, editor. Acquisition and utilization of aquatic habitat inventory information. American Fisheries Society, Western Division, Bethesda, Maryland.

Bjornn, T.C. 1969. Embryo survival and emergence studies, Job No. 5. Salmon and Steelhead Investigations Project No. F-49-R-6. Annual completion report. Idaho Fish and Game Department, 9 pp.

Bjornn, T.C. and D.W. Reiser. 1991. Habitat requirements of salmonids in streams. Pages 83-138 in W.R. Meehan, editor. American Fisheries Society special publication 19.

Bonneau, J.L. and D.L. Scarnecchia. 1998. Seasonal and diel changes in habitat use by juvenile bull trout (Salvelinus confluentus) and cutthroat trout (Oncorhynchus clarki) in a mountain stream. Canadian Journal of Zoology 76:783-790.

Bowlby, J.N. and J.C. Roff. 1986. Trout biomass and habitat relationships in southern Ontario streams. Transactions of the American Fisheries Society 115:503-514.

Bozek. M.A. and F.J. Rahel. 1991a. Comparison of streamside visual counts to electrofishing estimates if Colorado River cutthroat trout fry and adults. North American Journal of Fisheries Management 11:38-42.

Bozek, M.A. and F.J. Rahel. 1991b. Assessing habitat requirements of young Colorado River cutthroat trout by use of macrohabitat and microhabitat analyses. Transactions of the American Fisheries Society 120:571-581.

Brooker, M.P., D.L. Morris, and R.J. Hemsworth. 1977. Mass mortalities if adult salmon, Salmo salar in the R. Wye 1976. Journal of Applied Ecology14:409-417.

Brown, G.W. and J.T. Krygier. 1970. Effects of clear-cutting on stream temperature. Water Resources Research 6:1131-1139.

Buffagni, A. and E. Comin. 2000. Secondary production of benthic communities at the habitat scale as a tool to assess ecological integrity in mountain streams. Hydrobiologia 422/423:183-195. 
Burton, T.A., G.W. Harvey , and M. McHenry. 1990. Monitoring the effects of nonpoint sources of sediment pollution on salmonid incubation and egg to alevin survival. Proceedings of the annual conference western association fish and wildlife agencies 70:104-113.

Cederholm, C.J., L.M. Reid, and E.O. Salo. 1980. Cumulative effects of logging road sediment on salmonid populations in the Clearwater River, Jefferson County, Washington. Pages 38-74 in Proceedings from the conference on salmon spawning gravel: a renewable resource in the Pacific Northwest. Washington State University, Washington Water Research Center, Report 39, Pullman.

Chapman, D.W. 1966. Food and space as regulators of salmonid populations in streams. American Naturalist 100(913): 345-355.

Chapman, D.W. 1988. Critical review of variables used to define effects of fines in redds of large salmonids. Transactions of the American Fisheries Society 117:121.

Chapman, D.W. and K.P. McLeod. 1987. Development of criteria for fine sediment in the Northern Rockies Ecoregion. U.S. Environmental Protection Agency. Report 910 9-87-162. Seattle, Washington.

Chisholm, I.M. and W.A. Hubert. 1986. Influence of stream gradient on standing stock of brook trout in the Snowy Range, Wyoming. Northwest Science 60(2):137-139.

Cooper, A.C. 1965. The effect of transported stream sediments on survival of sockeye and pink salmon eggs and alevin. International Pacific Salmon Fisheries Commission Bulletin 18

Cordone, A.J. and D.W. Kelley. 1961. The influence of inorganic sediment on the aquatic life of streams. California Fish and Game 47(2):189-228.

Crisp, D.T. and P.A. Carling. 1989. Observations on siting, dimensions and structure of salmonid redds. Journal of Fish Biology 34:119-134.

Cunjak, R.A. and J.M. Green. 1983. Habitat utilization by brook char (Salvelinus fontinalis) and rainbow trout (Salmo gairdneri) in Newfoundland streams. Canadian Journal of Zoology 61:1214-1219.

Curtis, B. 1959. Changes in a river's physical characteristics under substantial reductions in flow due to hydroelectric diversion. California Fish and Game 45:181-188.

Danehy,R.J., N.H. Ringler, S.V. Stehman, and J.M. Hassett. 1998. Variability of fish densities in a small catchment. Ecology of Freshwater Fish 7:36-48. 
Dechant, T. and J.L. West. 1985. Characteristics and success of wild brown trout redds in 2 western North Carolina streams. Proceedings of the Annual Conference of the Southeast Association of Fish and Wildlife Agencies 39:86-96.

Dolloff, C.A., P.A. Flebbe, and M.D. Owen. 1994. Fish habitat and fish populations in a Southern Appalachian Watershed before and after Hurricane Hugo. Transactions of the American Fisheries Society 123: 668-678.

Dolloff, C.A., H.E. Jennings, and M.D. Owen. 1997. A comparison of basinwide and representative reach habitat survey techniques in three southern Appalachian watersheds. North American Journal of Fisheries Management 17:339-347.

Egglishaw, H.J. 1967. Food, growth and population structure of salmon. Freshwater and Salmon Fisheries Research 38: 1-32.

Elliot, J.M. 1973. The food of brown trout and rainbow trout (Salmo trutta and Salmo gairdneri) in relation to the abundance of drifting invertebrates in a mountain stream. Oecologia 12:329-347.

Elliot, J.M. 1990. Mechanisms responsible for population regulation in young migratory trout. The role of territorial behavior III. Journal of Animal Ecology 59: 803-818.

Elliot, J.M. 1993. The self-thinning rule applied to juvenile sea-trout, Salmo trutta. Journal of Animal Ecology 62:371-379.

Elliot, J.M., M.A. Hurley, and J.A. Elliot. 1997. Variable effects of droughts on the density of a sea-trout Salmo trutta population over 30 years. Journal of Applied Ecology 34:1229-1238.

Elliot, J.M. and M.A. Hurley. 1998. Population regulation in adult, but not juvenile, resident trout in a Lake District stream. Journal of Animal Ecology 67: 280-286.

Elliot, J.M. 2000. Pools as refugia for brown trout during two summer droughts: trout responses to thermal and oxygen stress. Journal of Fish Biology 56:938-948.

Everest, F.H., F.B. Lotspeich, and W.R. Meehan. 1982. New perspectives on sampling, analysis, and interpretation of spawning gravel quality. Pages 325-333 in N.B. Armantrout, editor. Acquisition and utilization of aquatic habitat inventory information. Western Division, American Fisheries Society, Portland, Oregon.

Everest, F.H., R.L. Beschta, J.C. Scrivener, K.V. Koski, J.R. Sedell, and C.J. Cederholm. 1987. Fine sediment and salmonid production - a paradox. Pages 98-142 in E. Salo and T. Cundy, editors. Streamside management and forestry and fishery interactions. University of Washington, College of Forest Resources, Contribution 57, Seattle. 
Fausch, K.D. 1984. Profitability stream position for salmonids: relating specific growth rate to net energy gain. Canadian Journal of Zoology. 62: 441-451.

Fausch, K.D., C.L. Hawkes, and M.G. Parsons. 1988. Models that predict standing crop of stream fish from habitat variables: 1950-1985. General Technical Report PNW-GTR-213. U.S. Department of Agriculture. Forest Service, Pacific Northwest Research Station, Portland Oregon.

Fausch, K.D. and T.G. Northcote. 1992. Large woody debris and salmonid habitat in small coastal British Columbia streams. Canadian Journal of Fisheries and Aquatic Sciences 49(4):682-693.

Flebbe, P.A. 1999, Trout use of woody debris and habitat in Wine Spring Creek, North Carolina. Forest Ecology and Management 114:367-376.

Flebbe. P.A. and C.A. Dolloff. 1995. Trout use of woody debris and habitat in Appalachian wilderness streams. North American Journal of Fisheries Management 15(3):579-590.

Fraley, J.J. and P.J. Graham. 1981. Physical habitat, geologic bedrock types and trout densities in tributaries of the Flathead River drainage, Montana. Pages 178-185 in N.B. Armantrout, editor. Acquisition and utilization of aquatic habitat inventory information. Western Division, American Fisheries Society, Bethesda, Maryland.

Fry, F.E.J., J.S. Hart, and K.F. Walker. 1946. Lethal temperature relations for a sample of speckled trout, Salvelinus fontinalis. University of Toronto Studies, Biological Series 54. Publication of the Ontario Fisheries Research Laboratory 66:9-35.

Gibson, R.J. 1978. The behavior of juvenile Atlantic salmon (Salmo salar) and brook trout (Salvelinus fontinalis) with regard to temperature and water velocity. Transactions of the American Fisheries Society 107:703-712.

Grant, J.W.A. and D.L. Kramer. 1990. Territory size as a predictor of the upper limit to population density of juvenile salmonids in streams.

Grayson, R.B., S.R. Haydon, M.D.A. Jayasuriya, and B.L. Finlayson. 1993. Water quality in mountain ash forests - separating the impacts of roads from those of logging operations. Journal of Hydrology 150:459-480.

Grost, R.T., W.A. Hubert, and T.A. Wesche. 1991. Field comparison of three devices used to sample substrate in small streams. North American Journal of Fisheries Management 11: 347-351. 
Hall, J.D. and R.L. Lantz. 1969. Effects of logging on the habitat of coho salmon and cutthroat trout in coastal streams. Pages 355-375 in T.G. Northcote, editor. Symposium on salmon and trout on streams. . H.R. MacMillan Lectures in Fisheries. University of British Columbia, Vancouver, Canada.

Hankin, D.G. and G.H. Reeves. 1988. Estimating total fish abundance and total habitat area in small streams based visual estimation methods. Canadian Journal of Fisheries and Aquatic Sciences 45:834-844.

Hartman, G.F., J.C. Scrivener, and M.J. Miles. 1996. Impacts of logging in Carnation Creek, a high-energy coastal stream in British Columbia, and their implication for restoring fish habitat. Canadian Journal of Fisheries and Aquatic Sciences 53(suppl. 1): 327-251.

Harvey, B.C. 1998. Influence of large woody debris on retention, immigration, and growth of coastal cutthroat trout (Oncorhynchus clarki clarki) in stream pools. Canadian Journal of Fisheries and Aquatic Sciences 55(8):1902-1908.

Hausle, D.A. 1973. Factors influencing embryonic survival and emergence of brook trout (Salvelinus fontinalis). Master's Thesis, University of Wisconsin, Stephens Point, Wisconsin.

Hausle, D.A. and D.W. Coble. 1976. Influence of sand in redds on survival and emergence of brook trout (Salvelinus fontinalis). Transactions of the American Fisheries Society 105:57-63.

Hawkins, C.P., M.L. Murphy, N.H. Anderson, and M.A. Wilzbach. 1983. Density of fish and salamanders in relation to riparian canopy and physical habitat in streams of the northwestern United States. Canadian Journal of Fisheries and Aquatic Sciences 40:1173-1185.

Heifetz, J., M.L. Murphy, and K.V. Koski. 1986. Effects of logging on winter habitat of juvenile salmonids in Alaskan streams. North American Journal of Fisheries Management 6:52-58.

Herger, L.G., W.A. Hubert, and M.K. Young. 1996. Comparison of habitat composition and cutthroat trout abundance at two flows in a small mountain streams. North American Journal of Fisheries Management 16:294-301.

Hillman, T.W., J.S. Griffith, and W.S. Platts. 1987. Summer and winter habitat selection by juvenile chinook salmon in a highly sedimented Idaho stream. Transactions of the American Fisheries Society 116:185-195. 
Hunt, R.L. 1971. The response of brook trout populations to habitat development in Lawrence Creek. Technical Bulletin 48. Wisconsin Department of Natural Resources, Madison, Wisconsin.

Hunt, R.L. 1979. Removal of woody streambank vegetation to improve trout habitat. Technical Bulletin 115. Wisconsin Department of Natural Resources, Madison, Wisconsin.

Huntingford, F.A., D. Aird, P. Joiner, K.E. Thorpe, V.A. Braithwaite, and J.D. Armstrong. 1999. How juvenile Atlantic salmon, Salmo salar L., respond to falling water levels: experiments in an artificial stream. Fisheries Management and Ecology 6:357-364.

Hutchings, J.A. 1994. Age- and size-specific costs of reproduction within populations of brook trout, Salvelinus fontinalis. Oikos 70:12-20.

Inoue, M. and S. Nakano. 1998. Effects of woody debris on the habitat of juvenile masu salmon (Oncorhynchus masou) in northern Japanese streams. Freshwater Biology 40(1):1-16.

Iwamoto, R.N., E.O. Salo, M.A. Madej, and R.L. McComas. 1978. Sediment and water quality: A review of the literature including a suggested approach for water quality criteria. U.S. Environmental Protection Agency, Region 10, Seattle, Washington. $151 \mathrm{pp}$.

Jonsson, N., B. Jonsson, and L.P. Hansen. 1998. The relative role of density-dependent and density-independent survival in the life cycle of Atlantic salmon Salmo salar Journal of Animal Ecology 67:751-762.

Kaller, M.D. 2000. Effects of sediment upon benthic macroinvertebrates in forested northern Appalachian streams. Master's Thesis. West Virginia University, Morgantown, West Virginia.

Kennedy, G.J.A. and C.D. Strange. 1982. The distribution of salmonids in upland streams in relation to depth and gradient. Journal of Fish Biology 20:579-591.

Klamt, R.R. 1976. The effects of coarse granitic sediment on the distribution and abundance of salmonids in the central Idaho batholith. Master's Thesis. University of Idaho, Moscow, Idaho.

Kocovsky, P.M., C. Gowan, K.D. Fausch, and S.C. Riley. 1997. Spinal injury rates in three wild trout populations in Colorado after eight years of backpack electrofishing. North American Journal of Fisheries Management 17:308-313. 
Koski, K.V. 1966. The survival of coho salmon (Oncorhynchus kisutch) from egg deposition to emergence in three Oregon streams. Master's Thesis, Oregon State University, Corvallis, Oregon.

Koski, K.V. 1981. The survival and quality of two stocks of chum salmon (Oncorhynchus keta) from egg deposition to emergence. Rapports et ProcesVerbaux des Reunions Conseil International pour l'Exploration de la Mer 178:330-333.

Koski, K.V. 1992. Restoring stream habitats affected by logging activities. Pages 344397 in G.W. Thayer, editor. Restoring the nation's marine environment. A Maryland Sea Grant Book, College Park, Maryland.

Kozel, S.J., W.A. Hubert, and M.G. Parsons. 1989. Habitat features and trout abundance relative to gradient in some Wyoming streams. Northwest Science 63(4):175182.

Kraft, M.E. 1972. Effects of controlled flow reduction on a trout stream, Journal of Fisheries Research Board of Canada 29:1405-1411.

Krumbein, W.C. and J.F. Pettijohn. 1938. Manual of sedimentary petrography, chapter 9 Appelton-Century-Crofts, Inc., New York. 228-267 pp.

Laine, P. and M. Rajasilta. 1999. The hatching success of Baltic herring eggs and its relation to female condition. Journal of Experimental Marine Biology and Ecology 237(1):61-73.

Lanka, R.P., W.A. Hubert, and T.A. Wesche. 1987. Relations of geomorphology to stream habitat and trout standing stock in small Rocky Mountain streams. Transactions of the American Fisheries Society 116:21-28.

LeCren, E.D. 1973. The population dynamics of young trout in relation to density and territorial behavior. Rapp. P.V. Reun. Int. Explor. Mer 164: 241-246.

Lestelle, L.C., M.L. Rowse, and C. Weller. 1993. Evaluation of natural stock improvement measures for Hood Canal coho salmon. Technical Report No. 93-1. Point No Point Treaty Council, Kingston, Washington.

Lewis, S.L. 1969. Physical factors influencing fish populations in pools of a trout stream. Transactions of the American Fisheries Society 98:14-19.

Lohr, S.C. and J.L. West. 1992. Microhabitat selection by brook and rainbow trout in a southern Appalachian stream. Transactions of the American Fisheries Society 121: 729-736. 
Lotspeich, F.B. and F.H. Everest. 1981. A new method for reporting and interpreting textural composition of spawning gravel. U.S. Forest Service Research Note PNW-139.

MacCrimmon, H.R. and J.S. Campbell. 1969. World distribution of brook trout, Salvelinus fontinalis. Journal of Fisheries Research Board of Canada 26:16991725.

MacCrimmon, H.R. and B.L. Gots. 1986. Laboratory observations on emergent patterns of juvenile rainbow trout Salmo gairdneri, relative to test substrate composition. Pages 63-76 in J.C. Miller, J.A. Arway and R.F. Carline, editors. Proceedings of the fifth trout stream habitat improvement workshop. Pennsylvania State Fish Commission, Harrisburg, Pennsylvania.

MaGee, J.P., T.E. McMahon, and R.F. Thurow. 1996. Spatial Variation in Spawning Habitat of cutthroat trout in a sediment-rich stream basin. Transactions of the American Fisheries Society 125:768-779.

Maret, T.R., T.A. Burton, G.W. Harvey, and W.H. Clark. 1993. Field testing a new monitoring protocols to assess brown trout spawning habitat in an Idaho stream. North American Journal of Fisheries Management 13:567-580.

Mason, J.C. 1976. Response of underyearling coho salmon to supplemental feeding in a natural stream. Journal Wildlife Management 40(4): 775-788.

Mason, J.C. and D.W. Chapman. 1965. Significance of early emergence, environmental rearing capacity, and behavioral ecology of juvenile coho salmon in stream channels. Journal of Fisheries Research Board of Canada 22(1):173-190.

McCuddin, M.E. 1977. Survival of salmon and trout embryos and fry in gravel-sand mixtures. Master's Thesis, University of Idaho, Moscow, Idaho.

McCullough, B.J. 1997. Effects of floods on brook trout populations in the Monongahela National Forest. Master's Thesis, Pennsylvania State University, University Park, Pennsylvania.

McFadden, J.T. 1961. A population study of the brook trout, Salvelinus fontinalis. Wildlife Monographs 11(7):1-73.

McKee, T.B., N.J. Doesken, and J. Kleist. 1993. The relationship of drought frequency and duration to time scales. Preprints, $8^{\text {th }}$ Conference on Applied Climatology, 17-22 January, Anaheim, California. 179-184 pp..

McNeil, W.J. 1969. Survival of pink and chum salmon eggs and alevins. Pages 101-117 in T.G. Northcote, editor. Symposium of salmon and trout in streams. H.R. MacMillan Lectures in Fisheries. University of British Columbia, Vancouver, Canada. 
McNeil, W.J. and W.H. Ahnell. 1964. Success of pink salmon spawning relative to size of spawning bed materials. U.S. Fish and Wildlife Service Special Scientific Report-Fisheries 469.

Meehan W.R., editor. 1991. Influences of forest and rangeland management on salmonid fishes and their habitats. American Fisheries Society Special Publication 19.

Meehan, W.R. and D.N. Swanston. 1977. Effects of gravel morphology on fine sediment accumulation and survival of incubating salmon eggs. U.S.D.A Forest Service Research Paper PNW-220. Pacific Northwest Range Experiment Station, Portland, Oregon. $16 \mathrm{pp}$.

Meisner, J.D. 1990. Potential loss of thermal habitat for brook trout, due to climactic warming, in two southern Ontario streams. Transactions of the American Fisheries Society 119:282-291.

Meyer, K.A. and J.S. Griffith. 1997. First-winter survival of rainbow trout and brook trout in the Henrys Fork of the Snake River, Idaho. Canadian Journal of Zoology 75:59-63.

Miranda, L.E. and W.D. Hubbard. 1994. Length-dependent winter survival and lipid composition of age-0 largemouth bass in Bay Springs Reservoir, Mississippi. Transactions of the American Fisheries Society 123:80-87.

Morgan, E.L. and J.R. Robinette. 1978, Life history study of brook trout (Salvelinus fontinalis), Great Smoky Mountains National Park. Environmental Biology Research Program \& Department of Biology, Tennessee Technological University, Cookeville, Tennessee.

Murphy, M.L. and W.R. Meehan. 1991. Stream ecosystems. Pages 17-46 in W.R. Meehan, editor. American Fisheries Society special publication 19.

Nelson, F.A. 1980. Evaluation of four instream flow methods applied to four trout waters in southwest Montana. Final report to U.S. Fish and Wildlife Service: contract 14-16-0006-78-046. Montana Department of Fish and Wildlife, Bozeman, Montana.

NOAA. 1999. Data provided by the National Oceanic and Atmospheric Administration.

NOAA/NCDC. 1999,2000. Data provided by the National Oceanic and Atmospheric Administration's National Climate Data Center. 
Overton, C.K., S.P. Wollrab, B.C. Roberts, and M.A. Radko. 1997. R1/R4 (Northern/Intermountain Regions) fish and fish habitat standard inventory procedures handbook. USFS General Technical Report INT-GTR-346.

Palmer, W.C. 1968. Keeping track of crop moisture conditions, nationwide: the new Crop Moisture Index. Weatherwise 21:156-161.

Peterson, R.H. 1978. Physical characteristics of Atlantic salmon spawning gravel in some New Brunswick streams. Fisheries and Marine Service Technical Report 785. $29 \mathrm{pp}$.

Peterson, R.H. and J.L. Metcalfe. 1981. Emergence of Atlantic salmon from gravels of varying composition: a laboratory study. Canadian Technical Report of Fisheries and Aquatic Sciences 1020.

Phillips, R.W., R.L. Lantz, E.W. Claire, and J.R. Moring. 1975. Some effects of gravel mixtures on emergence of coho salmon and steelhead trout fry. Transactions of the American Fisheries Society 104:461-466.

Platts, W.S. 1974. Geomorphic and aquatic conditions influencing salmonids and stream classification - with application to ecosystem management. U.S. Department of Agriculture, SEAM Program, Billings, MT. 199 pp.

Platts, W.S., M.A. Shirazi, and D.H. Lewis. 1979. Sediment particle sizes used by salmon for spawning with methods for evaluation. U.S. Environmental Protection Agency Ecological Research Series EPA-600/3-79-043.

Platts, W.S., W.F. Megahan, and G.W. Minshall. 1983. Methods for evaluating stream, riparian, and biotic conditions. U.S. Forest Service General Technical Report INT-138.

Platts, W.S. and R.L. Nelson. 1988. Fluctuations in trout populations and their implications for land-use evaluation. North American Journal of Fisheries Management 8:333-345.

Quinn, T.P. and N.P. Peterson. 1996. The influence of habitat complexity and fish size on overwinter survival and growth of individually marked juvenile coho salmon (Oncorhynchus kisutch) in Big Beef Creek, Washington. Canadian Journal of Fisheries and Aquatic Sciences 53:1555-1564.

Raikow, D.F., S.A. Grubbs, and K.W. Cummins. 1995. Debris dam dynamics and coarse particulate organic matter retention in an Appalachian mountain stream. Journal of the North American Benthological Society 14:535-546. 
Randolph, C.L. and R.G. White. 1984. Validity of the wetted perimeter method for recommending instream flows for salmonids in small streams. Research project technical completion report, Montana Water Resource Center, Montana State University, Bozeman, Montana.

Reid, L.M. and T. Dunne. 1984. Sediment production from forest road surfaces. Water Resources Research 20(11):1753-1761.

Reid, L.M., T. Dunne, and C.J. Cederholm. 1981. Application of sediment budget studies to the evaluation of logging road impact. New Zealand Journal of Hydrology 20:49-62.

Reiser, D.W. and T.A. Wesche. 1977. Determination of physical and hydraulic preferences of brown and brook trout in the selection of spawning locations. University of Wyoming, Water Resources Research Institute. Water Resources Research Series 64, Laramie, Wyoming.

Reiser, D.W. and R.G. White. 1988. Effects of two sediment size-classes on survival of steelhead and chinook salmon eggs. North American Journal of Fisheries Management 8:432-437.

Riley, S.C. and K.D. Fausch. 1992. Underestimation of trout population size by maximum likelihood removal estimates in small streams. North American Journal of Fisheries Management 12:768-776.

Ringler, N.H. 1970. Effects of logging on the spawning bed environment in two Oregon coastal streams. Master's Thesis. Oregon State University, Corvallis, Oregon

Roper, B. and D.L. Scarnecchia. 1996. A comparison of trap efficiency for wild and hatchery age-0 chinook salmon. North American Journal of Fisheries Management 16:214-217.

Rosenfeld, J.S. and J.J. Hudson. 1997. Primary production, bacterial production, and invertebrate biomass in pools and riffles in southern Ontario streams. Archivfuer-Hydrobiologie 139(3):301-316.

SAS Institute 1999. SAS statistical packages, version 8.0. SAS Institute, Cary, North Carolina.

Scarnecchia, D.L. and E.P. Bergersen. 1987. Trout production and standing crop in Colorado's small streams, as related to environmental features. North American Journal of Fisheries Management 7:315-330. 
Scrivener, J.C. and M.J. Brownlee. 1989. Effects of forest harvesting on spawning gravel and incubation survival of chum (Oncorhynchus keta) and coho (Oncorhynchus kisutch) in Carnation Creek, British Columbia. Canadian Journal of Fisheries and Aquatic Sciences 46:681-696.

Shepard, B.B., S.A. Leathe, T.M. Weaver, and M.D. Enk. 1984. Monitoring levels of fine sediment within tributaries to Flathead Lake, and impacts of fine sediment on bull trout recruitment. Pages 146-156 in F. Richardson and F.H. Hamre, editors. Wild Trout III. Trout Unlimited, Vienna, Virginia.

Silver, S.J., C.E. Warren, and P. Doudoroff. 1963. Dissolved oxygen requirements of developing steelhead trout and chinook salmon embryos at different water velocities. Transactions of the American Fisheries Society 92:327-343.

Slaney, P.A. and T.G. Northcote. 1974. Effects of prey abundance on density and territorial behavior of young rainbow trout (Salmo gairdneri) in laboratory stream channels. Journal of Fisheries Research Board of Canada. 31: 1201-1209.

Smith, R.W. and J.S. Griffith. 1994. Survival of rainbow trout during their first winter in the Henrys Fork of the Snake River, Idaho. Transactions of the American Fisheries Society 123:747-756.

Snucins, E.J., R.A. Curry, and J.M. Gunn. 1992. Brook trout (Salvelinus fontinalis) embryo habitat and timing of alevin emergence in a lake and a stream. Canadian Journal of Zoology 70:423-427.

Sogard, S.M. and B.L. Olla. 2000. Endurance of simulated winter conditions by age-0 walleye pollock: effects of body size, water temperature and energy stores. Journal of Fish Biology 56:1-21,

Spoor, W.A. 1990. Distribution of fingerling brook trout, Salvelinus fontinalis (Mitchell), in dissolved oxygen concentration gradients. Journal of Fish Biology.

Stewart, P.A. 1970. Physical factors influencing trout density in a small stream. Doctoral Dissertation, Colorado State University, Fort Collins, Colorado.

Strahler, A.N. 1957. Quantitative analysis of watershed geomorphology. Transactions of the American Geophysical Union 38(6):913-920.

Symons, P.E.K. 1971. Behavioral adjustment of population density to available food by juvenile Atlantic salmon. Journal of Animal Ecology 40(3):569-587.

Tagart, J.C. 1976. The survival from egg deposition to emergence of coho salmon in the Clearwater River, Jefferson County, Washington. Master's Thesis. University of Washington, Seattle, Washington. 
Tagart, J.V. 1984. Coho salmon survival from egg deposition to fry emergence. Pages 173-181 in J.M. Walton and D.B. Houston, editors. Proceedings of the Olympic wild fish conference. Fisheries Technology Program, Peninsula College, Port Angeles, Washington.

Tappel, P.D. and T.C. Bjornn. 1983. A new method of relating size of spawning gravel to salmonid embryo survival. North American Journal of Fisheries Management 3:123-135.

Thompson, J.M., E.P. Bergersen, C.A. Carlson, and L.R. Kaeding. 1991. Role of size, condition, and lipid content in the overwinter survival of age-0 Colorado squawfish. Transactions of the American Fisheries Society 120:346-353.

Titus, R.G. and H. Mosegaard. 1992. Fluctuating recruitment and variable life history of migratory brown trout, Salmo trutta L., in a small unstable stream. Journal of Fish Biology 41:239-255.

USEPA. 1996. National Water Quality Inventory: 1996 Report to Congress. U.S. Environmental Protection Agency, Washington, DC.

U.S. Geological Survey (USGS). 1977. National handbook of recommended methods for water-data acquisition. U.S. Geological survey v. p.

van den Berghe, E.P. and M.R. Gross. 1989. Natural selection resulting from female breeding competition in a Pacific salmon (coho: Oncorhynchus kisutch). Evolution 43:125-140.

Wald, A.R. 1975. The impact of truck traffic and road maintenance on suspended sediment from a 14' standard forest road. Master's Thesis, University of Washington, Seattle, Washington. 38 pp.

Wang, L., T.D. Simonson, and J. Lyons. 1996. Accuracy and precision of selected stream habitat estimates. North American Journal of Fisheries Management 16:340-347.

Ward, S.M. 2000. Provisional stage and discharge data for water year 2000 at the Greenbrier River gauging station at Durbin, West Virginia, were provided by the U.S. Geological Survey, West Virginia District.

Ward, S.M., B.C. Taylor, and G.R. Crosby. 2000. Water resources data, West Virginia, water year 1999. U.S. Geologic Survey Water-Data Report WV-99-1. 327 pp.

Waters, T.F. 1982. Annual production by a stream brook char population and its principal food. Environmental Biology of fishes 7(2):165-170. 
Wesche, T.A. 1974. Relationship of discharge reductions to available trout habitat for recommending suitable streamflows. Water Resources Research Institute, University of Wyoming. Completion Report to Office of Water Research and Technology \& Wyoming Game and Fish Commission, Project B-023-WYO.

White, G.C., D.R. Anderson, K.P. Burnham and D.L. Otis. 1982. Capture-recapture and removal methods for sampling closed populations. Los Alamos National Laboratory LA-8787-NERP, Los Alamos, New Mexico.

White, R.J. and R.L. Hunt. 1969. Regularly occurring fluctuations in year-class strength of two brook trout populations. Transactions of the Wisconsin Academy of Sciences, arts and letters 57: 135-153.

Williams, J.E., C.A. Wood, and M.P. Dombeck, editors. 1997. Watershed Restoration: Principles and Practices. American Fisheries Society, Bethesda, Maryland.

Witzel, L.D. and H.R. MacCrimmon. 1981. Role of gravel substrate on ova survival and alevin emergence of rainbow trout, Salmo gairdneri. Canadian Journal of Zoology 59:629-636.

Wohl, N.E. and R.F. Carline. 1996. Relations among riparian grazing, sediment loads, macroinvertebrate, and fishes in three central Pennsylvania streams. Canadian Journal of Fisheries and Aquatic Sciences 53(suppl. 1):260-266.

Wolman, M.G. 1954. A method of sampling coarse riverbed material. Transactions of the American Geophysical Union 35(6):951-956.

Wright, J.F. 1992. Spatial and temporal occurrences of invertebrates in a chalk stream, Berkshire, England. Hydrobiologia 248:11-30.

Wydoski, R.S. and E.L. Cooper. 1966. Maturation and fecundity of brook trout from infertile streams. Journal of Fisheries Research Board of Canada 235(5):623-619.

Young, M.K., W.A. Hubert, and T.A. Wesche. 1989. Substrate alteration by spawning brook trout in a southeastern Wyoming stream. Transactions of the American Fisheries Society 118:379-385. 


\section{Appendix:}

\section{Detailed Study Methodologies}

Study Area. - The study area is within the east central portion of the Monongahela National Forest, WV. The National Forest is located in the central Appalachian region. Study streams are first and second order (Strahler 1957) headwater streams located in the East Fork of the Greenbrier River (GR), and the North Fork of the South Branch of the Potomac River drainage's (PR). The two drainage basins lie on either side of the eastern continental divide. The underlying sedimentary geology consists of Chemung and Hampshire shale formations. Vegetation in the study area is predominately American beech (Fagus grandifolia), oak (Quercus spp.), black cherry (Prunus serotina) red maple (Acer rubra), and eastern hemlock (Tsuga canadensis). Stream elevations range from $900-1150 \mathrm{~m}$ above sea level. Annual precipitation at Elkins, WV (approximately 30 miles north of the study area) is $112 \mathrm{~cm}$ (National Oceanic and Atmospheric Administration's [NOAA] National Climatological Data Center [NCDC] 2000).

The seven streams studied were located in Pocahontas and Pendleton counties, WV (stream length and drainage locations in parentheses). They include Elleber Run (3.4 km) (GR), Lick Run (2.4 km) (GR), Little Low Place (1.2 km) (PR), Long Run (3.3 km) (GR), Mullenax Run (1.2 km) (GR), Poca Run (1.0 km) (GR) and Sawmill Run (2.2 $\mathrm{km})(\mathrm{PR})$. Study streams are not stocked and all support wild brook trout populations. Fishing pressure has not been quantified in the area, but seems to increase with stream size, reputation of the fishery (J. Hakala personal observation) and accessibility (McCullough 1997). Fishing pressure appeared to be light to non-existent in some streams, with greater use occurring in others during late winter and early spring. All 
streams except Little Low Place were un-manipulated watercourses. At Little Low Place there were 19 habitat improvement structures (k-dams, v-dams) constructed in the 1960's and 1990's. These structures have generally created large deep pools in their lee.

For all streams, sources of fine sediment exceeding natural production are presumably from roadways. Roads generally run parallel to streams and range in distance from 0 to approximately $100 \mathrm{~m}$ from the stream. Poca Run is the only stream not having an active forest road in its watershed and correspondingly had the lowest fine sediment levels measured. Sawmill Run likely had fine sediment inputs from both roads and agricultural activity located in its headwaters.

Sample Design. - Streams were selected for study based on data collected by the USFS in 1997 (unpublished data). Selected streams were representative of varying fine sediment loads and brook trout abundance. Sample size was a factor of available manpower and time constraints during the four sample periods. Streams in relative close proximity to one another (same watersheds) in geologic regions conducive to good year-round water quality were selected to minimize the effect geographic differences may have on salmonid densities (Lanka et al. 1987). Study streams were bounded at the terminal lower end by the confluence with another stream. The terminal upstream location was established at the confluence with another stream, road crossing, or where beaver (Castor canadensis) activity had altered the stream channel morphology.

Three representative $50 \mathrm{~m}$ sample reaches were established at the lower, middle and upper portions of each study stream. Reach locations were marked with survey flagging and impressionable metal tags at their respective downstream and upstream 
boundary. In summer 1999, the $50 \mathrm{~m}$ sample reaches were expanded to $100 \mathrm{~m}$ (Armour et al. 1983) to better account for naturally high variations in stream fish densities (Wydoski and Cooper 1965, Platts and Nelson 1988). Total sample reach length (3 x 100 $m$ in each stream) averaged $18 \%$ (range 9-29\%) of the total study stream lengths.

Habitat. - A quantitative assessment of instream physical habitat was conducted in June and July of 1999 and 2000. Physical stream habitat was assessed in each sample reach. Post-assessment of sample reaches was made to determine if the selected sample reaches were statistically representative of the entire study stream (discussion forthcoming). Habitat data for the entire stream were collected using the Basin Visual Estimation Technique (BVET) (Hankin and Reeves 1988).

Sample Reaches. - In early July 1999, and again in late June 2000, instream habitat assessments were conducted within all sample reaches. Water levels remained fairly constant during both surveys. U.S. Geological Survey (USGS) stage height data for the Greenbrier River at Durbin, WV (approximately 4 miles from study area) showed stage height during the surveys varied less than $0.01 \mathrm{~m}$ in both sample periods (S. Ward USGS, personal communication, preliminary data 2000). Instream habitat assessment included both a habitat-based (Dolloff et al. 1997) and transect-based (Platts et al. 1983) sample design to quantify variables at the sample reach scale. The habitat-based design was used for measurement of the following ten habitat variables: unit type, unit length, wetted stream width, unit area, pool to riffle ratio, average water depth, maximum pool depth, pool cover quality, amount of large woody debris (LWD) and area of suitable spawning 
substrate. Substrate size composition, substrate embeddedness and percent vegetative canopy cover data were collected using the transect technique.

Habitat dimensions were measured in all sample reaches. Three habitat unit types (pool, riffle or glides) were classified based on general descriptive guidelines (Bisson et al. 1982) modified for use in this study. Pool habitats had relatively slow water velocities, no surface disruption and a minimum depth of $10.0 \mathrm{~cm}$. Riffle habitats had relatively fast water velocities, surface disruption and a depth less than $10.0 \mathrm{~cm}$. Glide habitats were shallower than pools $(<10.0 \mathrm{~cm})$ with slower water velocities than riffle habitats and no surface disruption.

Habitat unit length was measured along the stream thalweg (deepest portion of stream channel) to the nearest $0.1 \mathrm{~m}$ meter using a fiberglass tape. The habitat width was measured to the nearest $0.1 \mathrm{~m}$ using a calibrated polyvinyl chloride (PVC) pipe. Three measures of wetted width at approximately $1 / 4,1 / 2$ and $3 / 4$ the unit length were recorded for each habitat unit (Dolloff et al. 1997). Average unit width was calculated by averaging all three transect widths. Unit area was determined from the product of the unit length and average width.

Water depths were recorded along the same three transects used to measure average unit width. Along each of the three transects, three depth measurements were recorded to the nearest $1.0 \mathrm{~cm}$ at $1 / 4,1 / 2$ and $3 / 4$ the transect width ( 9 measures total) (Overton et al. 1997). Average habitat unit water depth was calculated using standard methods to account for "0" water depth at the stream banks (Overton et al. 1997). The coefficient of variation (CV) was used to assess water depth complexity. 
Maximum water depth within pools was measured to the nearest $1.0 \mathrm{~cm}$ at the estimated deepest location. In addition, pool habitats were rated subjectively for their potential to provide cover for fish. The rating criteria were modified from Platts et al. (1983). Pool cover quality was rated on an improving scale of one to five.

Characteristics used in the ranking included water turbulence, overhanging banks/vegetation, LWD, and complexity of the bottom substrate. A rating of one would be given to a pool with little or no underwater turbulence, no undercut banks, no vegetation or LWD present, and a bottom substrate lacking complexity. A pool carrying a rating of five would have one or more of the following qualities: extensive underwater turbulence, undercut banks $(>4.0 \mathrm{~cm})$, the presence of overhanging vegetation, LWD or a complex bottom substrate with large crevices or rock undercuts. Intermediate values would be assigned based upon cover quality relative to other pools surveyed.

Large woody debris was quantified in all sample reaches and defined as being greater than 1.0 meter in length and larger than $10.0 \mathrm{~cm}$ in diameter (Flebbe 1999). All pieces of LWD within the bankfull area of the stream were enumerated, and lengths (nearest $0.10 \mathrm{~m}$ ) and trunk diameters (nearest $0.02 \mathrm{~m}$ ) were measured for calculation of mass volume. Tree diameter was measured at the estimated average diameter of the piece using a tree caliper. Each piece of LWD was characterized subjectively as "functioning" or "non-functioning" within the system. A functioning piece was either directly in the water, over the wetted area of the stream and below bankfull height, or stabilizing the streambank or streambed. Non-functioning pieces included those spanning or protruding over the stream above the bankfull height or lying on a dry area of the streambed wetted only during high flows. 
All suitable spawning substrate was quantified as an area (Bozek and Rahel 1991b, Magee et al. 1996). Substrate ranging from 4.0 to $30.0 \mathrm{~mm}$ in at least $7.0 \mathrm{~cm}$ of low velocity (generally tails of pools) water was considered suitable spawning substrate. These guidelines were based upon the author's personal observation of redd locations in fall 1998 and substantiated again in fall 1999.

Transect-based sampling was used to measure substrate size composition, substrate embeddedness and percent vegetative canopy cover. Transects perpendicular to the water flow were established at $5 \mathrm{~m}$ intervals in each $100 \mathrm{~m}$ sample reach (21 transects/reach). At each transect substrate size was measured for 5 particles for a total of 105/sample reach (>100 recommended by Overton et al. 1997) using the Wolman Pebble Count technique (Wolman 1954). Particles > $350 \mathrm{~mm}$, including bedrock, were recorded as $350 \mathrm{~mm}$. Those $<1.0 \mathrm{~mm}$ were recorded as $1.0 \mathrm{~mm}$. Substrate complexity was assessed by calculating the CV of all particles measured. Substrate embeddedness was estimated visually at each transect in the sample reach. Embeddedness was expressed as a percentage of large particle surface area impacted within finer sediment (Platts et al. 1983). Percent vegetative canopy cover over the stream at full leaf-out was visually estimated at each transect using a $13.0 \mathrm{~cm}$ long by $3.8 \mathrm{~cm}$ diameter sighting tube (PVC pipe). The observer looked skyward through the sighting tube and estimated the percent of the observation area containing vegetation.

Reach gradient was obtained using a clinometer over an approximately $50 \mathrm{~m}$ distance in each sample reach (Lanka et al. 1987). Readings were taken at similar habitat locations in the thalweg of the stream (Overton et al. 1997). For example, if the person 
holding the clinometer was standing at the head of pool, then the person holding the stadia rod also stood at the head of a pool.

Stream discharge was measured using United States Geologic Survey techniques (USGS 1977). Discharge measures were collected once a year during summer baseflow conditions. A single transect was established near the terminal end of each study stream in a channel section conducive (few channel obstructions, narrow wetted width) for good measurements (Overton et al. 1997). Water velocities were measured with a Marsh McBirnney velocity meter to the nearest $0.01 \mathrm{~m} / \mathrm{s}$. Discharge was calculated three times at the same location over a 15 min. period. All three measures were averaged to come up with a measure of total stream discharge expressed as $\mathrm{m}^{3} / \mathrm{sec}$.

Basinwide. - Basinwide habitat assessments were conducted in late June of 1999. Six habitat variables (habitat unit type, habitat unit length, average stream wetted width, maximum pool depth, pool cover quality and vegetative canopy cover) were quantified over the entire study stream using a modified version of the Basin Visual Estimate Technique (BVET) (Hankin and Reeves 1988). All habitat assessments were conducted using a two-person crew. Measures requiring observational interpretation were made by a single person to minimize observer bias (Roper and Scarnecchia 1995). No basinwide habitat assessment was conducted in 2000. BVET was only being used to establish that stream morphology in the representative sample reaches was similar to the entire stream. As no catastrophic events occurred (leaf litter never disturbed beyond bankfull width) between the 1999 basinwide assessment and the summer 2000 habitat survey, there was no reason to believe representative sample reach morphology had been altered. 
The wetted width of $20 \%$ of all three habitat types was visually estimated and then measured with a fiber glass tape. Average wetted width for all other habitat units encountered were visually estimated. Even though visual estimates of stream width can be made with good precision (Wang et al. 1996), a correction factor for the visually estimated wetted widths was calculated (Hankin and Reeves 1988). The correction factor was derived from the significant $(\mathrm{p}<0.05)$ relationship between the estimated and accurately measured habitat units. Maximum water depth and pool cover quality was measured for every pool encountered. Canopy cover was assessed at $20 \%$ of all habitat units. Habitat parameters were measured as described previously.

The basinwide habitat assessment allowed for statistical evaluation of the "representative" sample reaches. For a sample reach to be considered "representative" there is the underlying assumption that the sample reach chosen, is not morphologically different from the rest of the stream (Dolloff et al. 1997). The analysis was based upon average stream wetted width, maximum pool water depth, pool cover quality, canopy cover and pool and riffle area. The habitat variables were not normally distributed (Shapiro-Wilks normality test, SAS Institute 1999). A non-parametric t-test (Wilcoxon signed ranks test) was used to statistically evaluate if the representative sample reaches were morphologically similar to the rest of the stream. A t-test could not be used to assess pool and riffle area in the sample reaches relative to the entire stream. Instead, means determined for the entire stream, were examined to see if they fell within the $95 \%$ CI about the sample reach mean. 
Water Chemistry. - Water chemistry data were collected in situ at monthly intervals beginning in November 1998 and continuing through September 2000. Only pH was measured from November 1998 to July 1999. All measurements were generally made near baseflow conditions. Data were collected using an Oakton II pH probe, a YSI 30 conductivity meter and a Minisonde Hydro-lab. The following parameters were measured: $\mathrm{pH}$, dissolved oxygen (DO) $(\mathrm{mg} / \mathrm{L})$, percent $\mathrm{DO}$ saturation, and specific conductance $(\mathrm{ms} / \mathrm{cm})$. Measurements were taken at approximately the same location in the lowest downstream sample reach. Low flows as a result of drought prompted more intensive sampling of DO from July through August 1999. During the summer of 1999 (July - September) DO was measured in all three sample reaches. This allowed for a more quantitative assessment of DO conditions during drought-induced low flows.

To assess water quality during storm conditions, water samples were collected during two spring high flow events. Sampling was conducted on February 13, 2000 and May 24, 2000. Deep snow prevented all streams from being sampled during the February sample event. Water samples were collected in disposable Leur-Loc samplers and precleaned one-liter plastic sample containers. Samples were packed on ice to maintain temperatures below $4.0^{\circ} \mathrm{C}$ during transport. Proper chain-of-custody forms accompanied all samples. Samples were analyzed by the Appalachian Laboratory in Frostburg, MD. The following parameters were analyzed using United States Environmental Protection Agency guidelines: dissolved organic content (DOC) $(\mathrm{mg} / \mathrm{L}), \mathrm{pH}$, acid neutralizing capacity (ANC) (ueq/L), alkalinity (mg/L), calcium (mg/L), magnesium (mg/L), total aluminum $(\mathrm{mg} / \mathrm{L})$, organic aluminum $(\mathrm{mg} / \mathrm{L})$, and inorganic aluminum $(\mathrm{mg} / \mathrm{L})$. 
Water temperature data were collected continuously every hour from April 17, 1999 through September 2, 2000. Temperature data were recorded to the nearest $0.01{ }^{\circ} \mathrm{C}$ using Onset Corporation HOBO temperature loggers. Loggers were permanently affixed to the stream bottom using a PVC housing, chain and rebar to anchor the unit in place.

Daily precipitation data were collected from NOAA weather observatories located in Bartow WV and Elkins, WV. Precipitation collected at the Bartow station was compared to 30-year average precipitation data collected at the Elkins station to assess relative flow conditions for a given year or season (no such long-term data exists for the Bartow station).

Substrate Collection. - Substrate samples were collected during the fall of 1998 and 1999. Samples were collected from known brook trout redds over the entire study stream. Substrate sampling was not restricted to the sample reaches because of the difficulty in collecting adequate numbers of samples. An observer walked the stream looking for female or male/female pairs actively cleaning, defending or courting over a suitable substrate patch. To avoid erroneous sample collection, only redds occupied and readily visible by their "cleaned" appearance, were sampled. Identifying salmonid redd locations by their clean appearance is a widely used technique (Dechant and West 1985, Young et al. 1989, Grost et al. 1991). Two substrate samples were collected at each known redd location. One sample was taken directly from the redd, while the other was collected adjacent to the redd in an undisturbed area of the same gravel patch (Crisp and Carling 1989). From this point, samples collected adjacent to redd sites will be referred to as non-redd samples. Samples taken from the redd included the cleaned portion of the 
tailspill and the egg pocket. The non-redd sample was assumed to be representative of the background substrate composition prior to redd construction (Young et al. 1989, Grost et al. 1991). Collection of substrate from redd and non-redd locations allowed for evaluation of the effect hydraulic cleaning during redd construction had on removal of fine sediment from the substrate. A Friedmans test (non-parametric randomized block ANOVA) was used to detect significant $(\mathrm{p}<0.05)$ differences in the percent (by weight) less than a given particle size between redds and non-redds for the 1998 substrate data. A non-parametric test (Shapiro-Wilks normality test, SAS Institute 1999) was used as percent data are rarely normally distributed. An error in records did not permit comparison of redds and non-redds for the 1999 data. Redds and their corresponding non-redd samples in fall 1999 were not recorded.

The depth of egg deposition in the substrate is positively related to the size of the nest builder (Crisp and Carling 1989, Scrivener and Brownlee 1989), and inversely to substrate size (Bjornn and Reiser 1991 in Meehan 1991). It is recommended redd substrate samples be collected at the average maximum depth eggs would be found (Lotspeich and Everest 1981, Platts et al. 1983). Young et al. (1989) found brook trout $(<25 \mathrm{~cm})$ average egg pocket depth was $8.4 \mathrm{~cm}$ from the substrate surface. Considering that most spawning fish in these systems are $<25 \mathrm{~cm}$, substrate samples were taken to a depth of $8.0 \mathrm{~cm}$.

An average of 12 substrate samples (range 10-16 excluding Mullenax Run) were collected annually from each study stream. One-half of the twelve samples were collected from redds and the other half from non-redd locations. No redd samples were collected from Mullenax Run in either year due to extremely low trout densities and an 
inability to locate redds. This stream was excluded from further substrate analysis in both years, as comparison of suspected redd locations in Mullenax Run to known redd locations in other streams would be invalid. Sawmill Run was not sampled in fall 1998, as it was not a study stream until the following year.

Substrate samples were collected using a modification of the shovel technique (Grost et al. 1991). A plastic grain scoop (21.4cm long X $14.7 \mathrm{~cm}$ wide X 10cm high) was used because it made sample collection easier in small gravel patches, and potentially reduced loss of fine sediment during excavation. Substrate samples were placed in plastic bags for transport to the laboratory. Samples were oven dried at $100{ }^{\circ} \mathrm{C}$ for $36 \mathrm{~h}$. A graduated sieve series with square mesh sizes of 32.0, 16.0, 8.0, 4.0, 2.0, 1.0, $0.5,0.25,0.125$ and $0.063 \mathrm{~mm}$ were used to sift the samples. Each substrate sample was sifted for 7 minutes using a mechanical sieve shaker. The weight of substrate retained on each sieve was weighed to the nearest $1.0 \mathrm{gm}$ on an electronic scale. These data were used to calculate percent composition of each size class based on total sample weight. Percent composition of each size class was also calculated excluding substrate $>32 \mathrm{~mm}$. Truncating sediment data is a technique that has been used by other researchers to increase sample precision for smaller sediment sizes (Young et al. 1989, Grost et al. 1991).

The geometric mean diameter $\left(d_{g}\right)$ and sorting coefficient $\left(S_{o}\right)$ (Krumbein and Pettijohn 1938) were calculated for each sample using the equations of Lotspeich and Everest (1981). The $S_{o}$ is a measure of the particle distribution of the substrate. Sediment $>32 \mathrm{~mm}$ was excluded from the aforementioned calculations as substrate particles retained on the $32 \mathrm{~mm}$ sieve had an unknown maximum size, making 
determination of mid-point particle size used in the calculation of $d_{g}$ impossible. These two values were used to calculate fredle index $\left[f_{i}\left(f_{i}=d_{g} / S_{o}\right)\right]$ values for each substrate sample (Lotspeich and Everest 1981).

Percent fine sediment, $d_{g}$ and $f_{i}$ are correlated (Lotspeich and Everest 1981, Everest et al. 1987, Magee et al. 1996). To ascertain which fine sediment sizes most influenced substrate permeability, as measured by $d_{g}$ and $f_{i}$, use of non-linear regression was employed. Values obtained for $d_{g}$ and $f_{i}$ were regressed on all sediment size classes for redd and non-redds separately. Substrate $>32 \mathrm{~mm}$ was excluded for this analysis. Inverse relations were considered to indicate a negative influence of that size class on substrate permeability and vice-versa. Sediment sizes identified as negatively influencing either measure were then used in stepwise multiple linear regression (MLR) to identify the most influential size class. Dependent variables in the MLR analysis were natural log-transformed.

Shovel and Grain Scoop Experiment. - A controlled experiment was conducted to test if significant differences existed between sediment composition of samples collected with the grain scoop (21.4 cm long X $14.7 \mathrm{~cm}$ wide) and a standard shovel as used by the USFS $(28.2 \mathrm{~cm}$ long X $22.6 \mathrm{~cm}$ wide). Six plastic containers $(55.0$ X $45.0 \mathrm{~cm})$ were filled to a depth of approximately $12 \mathrm{~cm}$ with substrate of a known composition. Substrate composition was the same in each container and similar to natural compositions found in the study area.

Filled containers were placed in a stream at a location of similar water depth and velocity as brook trout redds were observed. Two adjacent substrate samples were 
removed from each of the six containers, one using the grain scoop and the other using the shovel. Samples were taken far enough apart in the container so as not to disturb substrate being sampled by the other device. Samples were taken to a depth of $8 \mathrm{~cm}$. Similar amounts of gravel were removed by both devices. Substrate samples were processed as described earlier in this section.

A non-parametric randomized block ANOVA (Friedmans test) was used to test for significant $(\mathrm{p}<0.05)$ differences in the percent composition (by weight) of each size class between sampling techniques. The analysis used the individual containers $(n=6)$ as the blocking unit.

Population Surveys. - Population surveys were conducted in October 1998, July 1999, October 1999 and July 2000 during baseflow conditions. The fall (October) sample surveys were conducted in early October, 2-3 weeks prior to the peak of brook trout spawning. The summer (July) sample surveys were conducted from early to mid-July when young of the year trout (YOY) were $40-70 \mathrm{~mm}$. Capture efficiency of trout smaller than $30 \mathrm{~mm}$ is low (LeCren 1973). All population surveys were conducted within each of the three $100 \mathrm{~m}$ sample reaches in each study stream. Sample reaches were blocked at the upstream and downstream end using $2.0 \mathrm{~mm}$ square-mesh blocking nets. Block nets were not used at the upstream reach boundary if a natural obstruction to fish movement was present. Fish were collected using a Coffelt Model 12 backpack electrofisher. The direct pulsed DC electrofishing unit was set at a frequency of 60 hertz and a voltage range of 250-400 V depending on water conductivity. Kocovsky et al. (1997) demonstrated no long-term population effects on a salmonid population electrofished for eight years using similar techniques under comparable stream conditions. All fish 
species were removed using a standard three-pass removal technique (as recommended by Riley and Fausch 1992). Occasionally a fourth pass was completed if there was unsatisfactory depletion between the second and third passes.

The CAPTURE program (White et al. 1982) was used to calculate separate maximum-likelihood population estimates and $95 \% \mathrm{CI}$ for age 0 (YOY) and age $1+$ (adult) brook trout. If less than 30 fish (YOY or adult) were captured in a given section, then the actual number captured was used in lieu of an estimate. This is based on the findings of Riley and Fausch (1992) that the maximum-likelihood removal estimate "performs poorly" at sample sizes less than 30 individuals. Fewer than 30 fish (YOY or adult) per section were frequently caught during the course of the study. The CAPTURE program runs a chi-square analysis to determine if the model assumption of equal catch probability between passes was satisfied. If the assumption was not satisfied for a particular population estimate, then the raw total catch was bootstrapped using the average catch efficiency for those estimates satisfying the model's assumption. Failure to meet the model's assumption occurred infrequently. Catch efficiency was calculated as the quotient of the actual number of fish captured and the derived population estimate for a sample reach (Lohr and West 1992).

Depletion removal of non-trout species was poor as a result of prioritizing the capture of brook trout during sampling. For non-trout species, total catch was used as opposed to mathematically estimating the population size.

All brook trout captured were measured (total length $=\mathrm{TL}$ ) to the nearest $1.0 \mathrm{~mm}$ and weighed using a Pesolo spring scale to the nearest $1.0 \mathrm{gm}$. All other species were enumerated and weighed in species specific conglomeration. As brook trout spawn in the 
fall, those captured in the October 1998 and 1999 sample periods were checked for sex and ripeness (presence of eggs or milt). This allowed for determination of length at maturity, and sex ratios prior to the peak spawning period (Beard and Carline 1991). Determination of age 0 (YOY) and age 1+ (adult) fish was done through analysis of length-frequency histograms. Age at length was verified for 40 fish using scale samples. Brook trout per-capita birth rate (production) was estimated as the ratio of the number of YOY captured in summer surveys to numbers of adult females captured in the previous fall survey. Estimate of the number of females was calculated by multiplying the percent of females in a section (as determined by checking for ripeness) by the total number of adult brook trout captured.

To demonstrate relative YOY density at the time of summer sampling was representative of densities shortly after emergence, visual counts of YOY were conducted over $50 \mathrm{~m}$ of every sample reach. Bozek and Rahel (1991a) found a strong correlation (r $=0.92, \mathrm{p}<0.05)$ between stream bank visual counts of YOY cutthroat trout and subsequent electrofishing survey results. Young of the year salmonids are often found in the shallow stream margins (Kennedy and Strange 1982, Bozek and Rahel 1991b) making them more readily visible from the stream bank.

Visual counts of YOY were conducted in May of 1999 over three consecutive days. One side of the stream bank was walked at a constant pace counting all YOY observed from the water's edge to the center of the stream. This method effectively sampled $1 / 4$ of the entire $100 \mathrm{~m}$ sample reach. The total number of fish observed in the section was then multiplied by four in order to account for the other $3 / 4$ of the sample reach not observed. Average number of YOY was calculated over the three observation 
days. Simple linear regression analysis was used to compare relative abundance of YOY observed to numbers captured during subsequent July electrofishing surveys. No counts occurred in May of 2000 as relatively high flows throughout the period made visual counts of fry impossible.

Data Analysis. - All statistical analyses were completed using the SAS 8.0 statistical software package (SAS Institute 1999). Statistical analysis methods varied with application, but included simple and multiple linear regression, non-linear regression, ANOVA, and non-parametric ANOVA and t-tests. Significance was set at the 0.05 level for all tests.

Simple linear regression was used to test significance of each habitat variable in relation to brook trout density and biomass between streams. Habitat variables assessed included: measures of sediment composition, average stream water depth, water depth complexity, average maximum pool depth, pool cover quality, number of pool habitats, pool and riffle area, pool to riffle ratio, average substrate particle size, substrate complexity, substrate embeddedness, amount of spawning substrate, amount of functioning and non-functioning LWD, and total amount of LWD. This univariate analysis was not intended for the development of predictive models, but rather for identifying habitat variables significantly influencing brook trout population size. Separate analyses were completed for YOY, adult and total brook trout density and biomass. Testing within stream differences for adult and YOY densities in each stream over two years, attributed to the 22 habitat variables analyzed in both 1999 and 2000, yielded 29 significant differences in 616 separate statistical tests. Significant differences 
within streams were rare, with no more than might be expected by chance alone (5\%), and none that elicited any meaningful trend. This allowed the data for all three sample reaches to be averaged over the entire study stream for comparison between streams.

All variables identified as significantly influencing brook trout abundance in the univariate analysis were then considered for use in a stepwise multiple linear regression (MLR) (Lanka et al. 1987). Multiple linear regression analysis was conducted to identify the order of importance key variables had on brook trout abundance. Two to three significant variables were considered for inclusion in the MLR analysis only after their ecological significance was assessed. The assessment procedure was based upon field observation of the perceived important processes acting on brook trout populations in the study area. This technique potentially reduces the chance of reporting erroneous findings based solely on statistical interpretation, but possibly increases the likelihood of researcher bias. To avoid parameter redundancy, if two variables were significantly correlated then only one was used in the MLR analysis (Lanka et al. 1987).

To test if brook trout body condition and biomass had decreased as a result of drought conditions a non-parametric ANOVA (Kruskal-Wallis ANOVA) was used. Brook trout body condition and density were statistically compared by life stage (YOY or adult) between the July 1999 and July 2000 sample periods. Brook trout condition (Fulton-type) was calculated using the formula $\mathrm{K}=\mathrm{W} / \mathrm{L}^{3}$ (where $\mathrm{K}=$ condition; $\mathrm{L}=$ total fish length; W = fish weight) (Anderson and Gutreuter 1983). 


\title{
James P. Hakala
}

\author{
West Virginia University \\ Division of Forestry \\ P.O. Box 6125 \\ Morgantown, WV 26506-6125 \\ (304) 293-2941 extension 2314 \\ Fax: (304) 293-2441 \\ e-mail: jimakah@aol.com
}

\section{EDUCATION:}

Master of Science - Fish and Wildlife Resources: West Virginia University, Morgantown, WV.

Received December 2000

Bachelor of Technology - Fisheries and Aquaculture: State University of New York College of Agriculture and Technology, Cobleskill, NY.

Received May 1996.

Associate of Applied Science - Fisheries and Wildlife Biology: State University of New York College of Agriculture and Technology, Cobleskill, NY.

Received May 1994.

\section{GRADUATE COURSE WORK:}

Fisheries Management

Population Ecology

Statistical Methods I \& II

Introduction to GIS
Fish and Wildlife Toxicology

Quantitative Ecology

Biostatistics

Wildlife and Fisheries Seminar

\section{PROFESSIONAL EXPERIENCE:}

Research Assistant - West Virginia University

Morgantown, WV

August 1998 - December 2000

Environmental Consultant - Versar Inc.

Columbia, MD

September 1996 - August 1998

Environmental Consultant - Biohabitats Inc.

Timonium, MD

June 1996 - September 1996 
Student Manager - S.U.N.Y. Cobleskill Fish Hatchery

Cobleskill, NY

September 1994 - December 1994 and September 1995 - December 1995

Research Assistant - Environmental Monitoring and Assessment Program (EMAP) Syracuse, NY

June 1995 - August 1995

Aquatic Sciences Intern - S.U.N.Y. Oneonta Biological Field Station Cooperstown, NY

June 1994 - August 1994 and June 1993 - August 1993

\section{PROFESSIONAL SOCIETYS / PRESENTATIONS / CERTIFICATIONS:}

Member of the American Fisheries Society (AFS) \& West Virginia Chapter of AFS Certified through AFS as an Associate Fisheries Professional

Tri-state American Fisheries Society Meeting, March 2000: presented paper Northeast Division AFS Annual Meeting, April 2000: presented paper: Received "Best Student Presentation Award"

East Coast Trout Culture and Management Symposium, June 2000: presented paper National American Fisheries Society Conference, August 2000: presented paper Red Cross certified in first aid and CPR

\section{SPECIAL SKILLS}

- Microsoft Word, Excel and Power Point

- Federally trained in electrofishing safety

- PIT tagging, polymer tagging techniques

- Formally trained in U.S. Army Corp of Engineers wetland delineation techniques
- SAS statistical software

- backpack electrofishing

- Stream habitat assessment 